\title{
COMPONENTES MONOCÍCLICOS DO CANCRO CÍTRICO NO SISTEMA Xanthomonas axonopodis pv. citri-LIMÃO TAHITI- Phyllocnistis citrella, SOB CONDIÇÕES CONTROLADAS
}

\author{
ROCK SEILLE CARLOS CHRISTIANO
}

Dissertação apresentada à Escola Superior de Agricultura "Luiz de Queiroz", Universidade de São Paulo, para obtenção do título de Mestre em Agronomia, Área de Concentração: Fitopatologia.

PIRACICABA

Estado de São Paulo - Brasil

Dezembro de 2003 


\title{
COMPONENTES MONOCÍCLICOS DO CANCRO CÍTRICO NO SISTEMA Xanthomonas axonopodis pv. citri-LIMÃO TAHITI- Phyllocnistis citrella, SOB CONDIÇÕES CONTROLADAS
}

\author{
ROCK SEILLE CARLOS CHRISTIANO \\ Engenheiro Agrônomo
}

Orientador: Prof. Dr. ARMANDO BERGAMIN FILHO

Dissertação apresentada à Escola Superior de Agricultura "Luiz de Queiroz", Universidade de São Paulo, para obtenção do título de Mestre em Agronomia, Área de Concentração: Fitopatologia.

PIR A C I C A B A

Estado de São Paulo - Brasil

Dezembro de 2003 
Dados Internacionais de Catalogação na Publicação (CIP) DIVISÃO DE BIBLIOTECA E DOCUMENTAÇÃO - ESALQ/USP

\author{
Christiano, Rock Seille Carlos \\ Componentes monocíclicos do Cancro Cítrico no sistema Xanthomonas \\ axonopodis pv. citri-Limão Ttahiti-Phyllocnistis citrella, sob condições controladas / \\ Rock Seille Carlos Christiano. - - Piracicaba, 2003. \\ 104 p. : il. \\ Dissertação (mestrado) - - Escola Superior de Agricultura Luiz de Queiroz, \\ 2003. \\ Bibliografia. \\ 1. Citricultura 2. Doenças de plantas 3. Efeito da temperatura 4. Efeito do \\ molhamento 5. Lagarta-minadora-dos-citros 6. Limão 7. Xanthomonas I. Título
}

CDD 634.3

"Permitida a cópia total ou parcial deste documento, desde que citada a fonte - O autor" 
A todo brasileiro

que do fruto da terra

colhe o seu sustento,

À minha 'pequena família':

meus pais, Antonio e Theia, pelo amor e exemplo de determinação e coragem; meus irmãos, Júnio, Neto, Carlinho, Cássia e Vanessa, pelo afeto e presença constante,

À minha'Pretinha', por tudo,

dedico. 
A Deus, pela luz que me guia;

À Escola Superior de Agricultura Luiz Queiroz, Setor de Fitopatologia, pela oportunidade de realização do curso de Mestrado;

Ao Prof. Dr. Armando Bergamin Filho, por me iniciar no caminho da Epidemiologia;

À Prof. Dra. Lílian Amorim, pelo brilhantismo estatístico:

Ao Prof. Dr. José R. P. Parra, por ter disponibilizado o Setor de Entomologia;

Ao amigo Dr. Waldir Cintra de Jesus, pela co-orientação no andamento do projeto e, principalmente, pela amizade:

À amiga Prof. Dra. Maristela Dalla Pria, pela ajuda constante na condução dos experimentos, paciência e, contudo, por sua pessoa;

À Adriana M. Nascimento, pela amizade e apoio fundamental nos experimentos com P. citrella, da qual sem o trabalho não seria possível;

Ao estagiário Cássio Stephan, pela colaboração e amizade;

Aos professores do Setor da Fitopatologia, pelos conhecimentos ministrados, e aos funcionários, pelos momentos descontraídos:

A todos os amigos, cujos os muitos nomes estão omitidos, por fazerem com que 0 Mestrado fosse não somente um período de aprimoramento profissional, mas também de crescimento pessoal;

À FAPESP, por tornar um sonho em realidade;

À Universidade Federal de Lavras, pela formação profissional, e aos Prof. Dr. Ludwig Pfenning, Vicente Gualberto, Renzo Von Pinho e a pesquisadora Dra. Magnólia Campos pelo incentivo:

agradeço. 


\section{SUMÁRIO}

Página

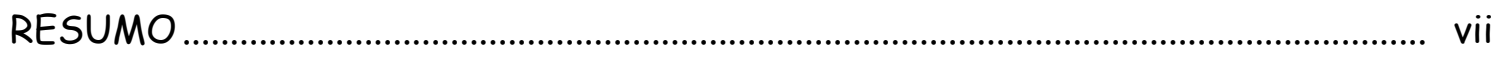

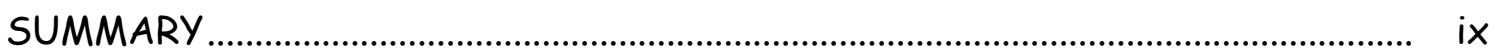

1 INTRODUÇÃO

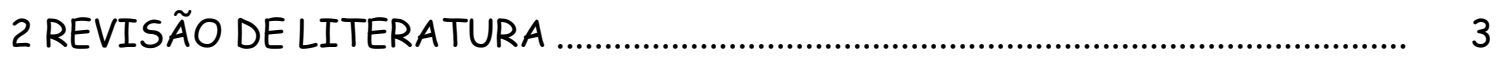

2.1 Citricultura Paulista, aspecto econômico .................................................................. 3

2.2 Importância do Cancro Cítrico e sua origem ........................................................... 4

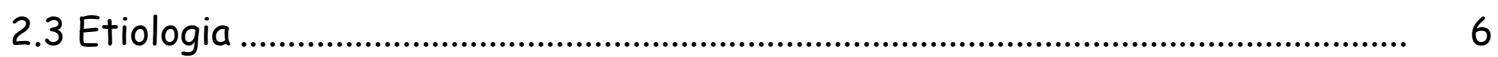

2.4 Lagarta Minadora dos Citros e seu sinergismo com X. axonopodis pv. citri... 8

2.5 Epidemiologia do Cancro Cítrico ......................................................................... 12

2.6 Controle do Cancro Cítrico .................................................................................. 18

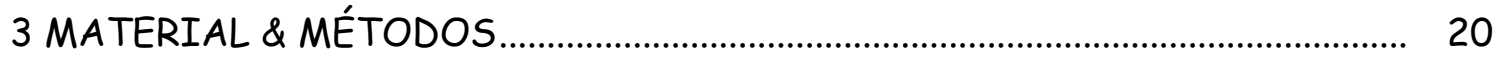

3.1 Aquisição de mudas .................................................................................................. 20

3.2 Obtenção de inóculo ........................................................................................ 21

3.3 Segurança fitossanitária ................................................................................. 21

3.4 Mudas com Lagarta Minadora dos Citros ............................................................ 22

3.6 Via de penetração de $X$. axonopodis pv. citrie a concentração de inóculo na severidade do Cancro Cítrico ...................................................................................... 24

3.7 Idade da folha intacta, do ferimento mecânico e da injúria de LMC no desenvolvimento do Cancro Cítrico 
3.8 Efeito da temperatura e do período de molhamento foliar no desenvolvimento

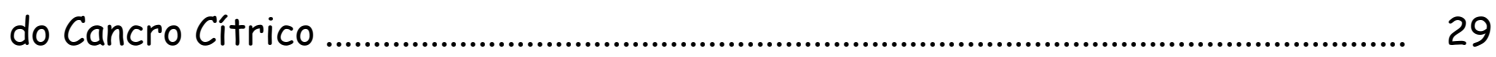

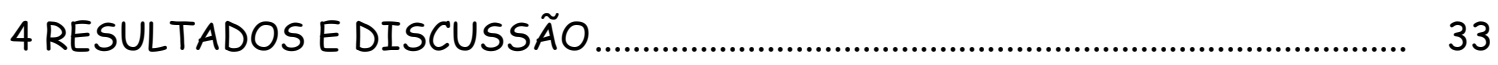

4.1 Via de penetração de $X$. axonopodis pv. citrie a concentração de inóculo na severidade do Cancro Cítrico. ................................................................................. 33

4.2 Idade da folha intacta, do ferimento mecânico e da injúria de LMC no

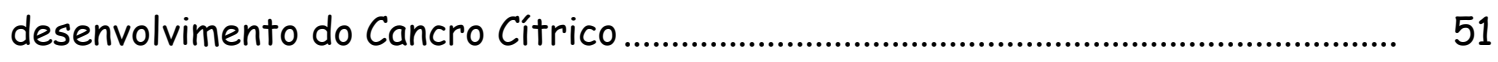

4.3 Efeito da temperatura e do período de molhamento foliar no desenvolvimento

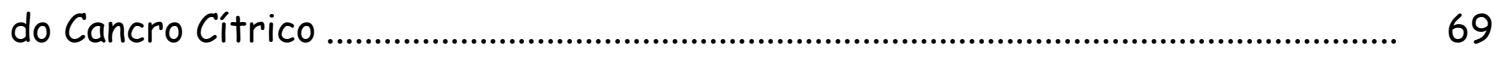

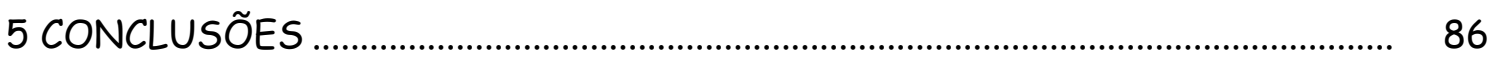

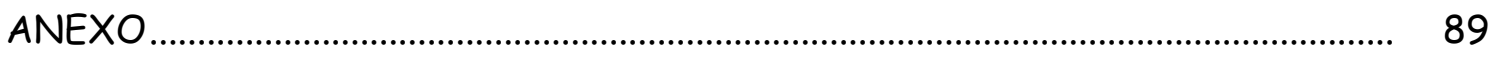

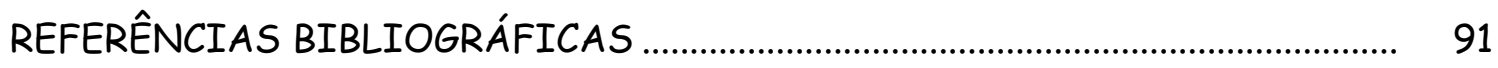




\title{
COMPONENTES MONOCÍCLICOS DO CANCRO CÍTRICO NO SISTEMA Xanthomonas axonopodis pv. citri-LIMÃO TAHITI-Phyllocnistis citrella, SOB CONDIÇÕES CONTROLADAS
}

\author{
Autor: Rock Seille Carlos CHRISTIANO \\ Orientador: Prof. Dr. Armando BERGAMIN FILHO
}

\section{RESUMO}

O Cancro Cítrico (CC), causado por Xanthomonas axonopodis pv. citri (Xac) é uns dos mais graves problemas fitossanitário da citricultura paulista. A partir da introdução da Lagarta Minadora dos Citros (LMC), Phyllocnistis citrella, o comportamento do CC mudou drasticamente, tornando-se mais severo. Para compreender a interação de Xac e da LMC em Limão Tahiti foram conduzidos, em condições controladas, três experimentos: $(A)$ influência da via de penetração de Xac (estômato, ferimento mecânico e injúria de LMC das fases ovo, $1^{\circ}$ ínstar, $3^{\circ}$ ínstar e pupa) e das concentrações de inóculo de $10^{1}, 10^{2}, 10^{4}$ e $10^{6} \mathrm{UFC} / \mathrm{mL}$ na infecção de Xac, (B) efeito da idade do ferimento mecânico, da injúria de LMC e da folha intacta no progresso do $C C$; $(C)$ influência da temperatura e do período de molhamento no desenvolvimento do $C C$. No experimento $A$, a concentração mínima de inóculo para causar $C C$ via penetração de Xac por estômato foi de $10^{4} \mathrm{UFC} / \mathrm{mL}$; $10^{2}$ UFC/mL para via ferimento mecânico e injúria de LMC na fase ovo e $1^{\circ}$ ínstar; e 
$10^{1} \mathrm{UFC} / \mathrm{mL}$ para via injúria fase $3^{\circ}$ ínstar e pupa. $A$ injúria da fase $3^{\circ}$ ínstar e pupa proporcionaram maior severidade em relação às outras vias de penetração nas concentrações testadas (aproximadamente 6 vezes maior que a severidade em folha intacta a $10^{6} \mathrm{UFC} / \mathrm{mL}$ ). As severidades em folha com ferimento mecânico e com injúria da fase ovo e $1^{\circ}$ ínstar não diferiram da folha intacta. No experimento $B$, o ferimento mecânico entre 0 e 6 dias após o ferimento da folha ( 0 a 6 dias de idade), injúria de LMC entre 0 e 32 dias após a ovoposição de $P$. citrella na folha ( 0 a 32 dias de idade) e folha intacta entre 0 e 35 dias após a emissão da folha ( 0 a 35 dias de idade) foram suscetíveis a Xac. A severidade decresceu linearmente com o aumento da idade do ferimento e da folha intacta. A severidade, em relação à idade de injúria, variou em função do modelo Beta generalizado, com ponto de inflexão aos 18 dias. A máxima severidade estimada em folha com injúria foi 10 vezes maior que em folha intacta. No experimento $C$, observou-se que para os menores intervalos de aparecimento de lesões e $100 \%$ de incidência de CC, as condições ótimas foram de 25 a $35^{\circ} \mathrm{C}$ com período mínimo de molhamento de 4 horas. O modelo Beta-monomolecular ajustou-se bem à variação da severidade em função da temperatura e da duração do molhamento foliar. As temperaturas mínima e máxima estimadas foram de 14,9 e $42^{\circ} \mathrm{C}$. A máxima severidade estimada foi determinada para o molhamento de 24 horas a $31,7^{\circ} \mathrm{C}$. Em geral, a injúria de LMC nas fases acima de $3^{\circ}$ ínstar influenciou na infecção de Xac possibilitando infecções mesmo em baixas concentrações de inóculo (10 células $/ \mathrm{mL}$ ) e durante um longo período (32 dias). Em folhas com injúria de $L M C$, a severidade de $C C$ pode ser 10 vezes maior que em folha intacta. As condições favoráveis para a infecção de Xac são de 25 a $35^{\circ} \mathrm{C}$ e a bactéria não demanda longos períodos de molhamento foliar (acima de 4 horas). Por esses resultados, conclui-se que a LMC tem papel relevante na epidemiologia do $C C$. 
MONOCYCLIC COMPONENTS OF THE ASIATIC CITRUS CANKER IN THE SYSTEM: Xanthomonas axonopodis pv. citri-TAHITI LIME-Phyllocnistis citrella, UNDER CONTROLLED CONDITIONS

\author{
Author: Rock Seille Carlos CHRISTIANO \\ Adviser: Prof. Dr. Armando BERGAMIN FILHO
}

\title{
SUMMARY
}

The Asiatic Citrus Canker ( $A C C$ ), caused by Xanthomonas axonopodis pv. citri (Xac) is one of the most serious problems of citrus in São Paulo State, Brazil. After the introduction of Citrus Leafminer (CLM), Phyllocnistis citrella, the behavior of ACC changed drastically, becoming more severe. To understand the interaction of Xac and CLM on Tahiti Lime, it were, under controlled conditions, carried three experiments: $(A)$ influence of the way of Xac penetration (stomata, mechanical wound and CLM injury of the stage: egg, 1st instar, 3rd instar and pupa) and of the inoculum concentrations of $10^{1}, 10^{2}, 10^{4}$ and $10^{6} \mathrm{CFU} / \mathrm{mL}$ in the Xac infection; (B) effect of the age of mechanical wound, of CLM injury and of unwounded leaf in the progress of the $A C C ;(C)$ influence of the temperature and of the period of leaf wetness in the development of the ACC. In the experiment $A$, the minimum inoculum concentration to cause $A C C$ by penetration of Xac through 
stomata was of $10^{4} \mathrm{CFU} / \mathrm{mL} ; 10^{2} \mathrm{CFU} / \mathrm{mL}$ by mechanical wound and CLM injury of egg stage and 1st instar; and $10^{1} \mathrm{CFU} / \mathrm{mL}$ by injury of $3 \mathrm{rd}$ instar and pupa stage. The injury of $3 r d$ instar and pupa stage have generated higher severity in relation to other ways of penetration on all concentrations (about 6 times more than the severity in unwounded leaf on $10^{6} \mathrm{CFU} / \mathrm{mL}$ ). The severities in leaf with mechanical wound and with injury of egg stage and 1st instar have not differed from the unwounded leaf. In the experiment $B$, the mechanical wound between 0 and 6 days (0-6 days of age), the CLM injury between 0 and 32 days after eggs laying of $P$. citrella (0-32 days of age) and unwounded leaf between 5 and 35 days (5-35 days of age) have shown susceptibility to Xac. The severity decreased linearly with increasing age of the wound and age of unwounded leaf. In relation to age of injury, the severity varied in function of generalized Beta model and the inflection point was 18 days. The maximum severity in leaf with injury was 10 times bigger than in unwounded leaf. In the experiment $C$, the optimum conditions appearance of lesions and $100 \%$ of incidence were $25-35^{\circ} \mathrm{C}$ under minimum wetness duration of 4 hours. The Beta-monomolecular function provided a good description of severity variation in relation to the temperature and duration of leaf wetness. The estimated minimum and maximum temperatures were 14.9 and $42^{\circ} \mathrm{C}$. The estimated maximum severity was determined under wetness of 24 hours and $31.7^{\circ} \mathrm{C}$. In general, the LMC injury (up to $3 r$ d instar stage) has influenced in the XaC infection, it has increased the efficiency of bacterium penetration still on low inoculum concentration and it has allowed Xac infection for long period (32 days). In leaf with CLM injury, the severity can be 10 times bigger than in unwounded leaf. The Xac infection is favored under $25-35^{\circ} \mathrm{C}$ and the Xac does not demand long periods of leaf wetness (more than 4 hours). 


\section{INTRODUÇÃO}

O Brasil vem se mantendo líder na produção mundial de citros, com um patrimônio representado por um parque de mais de 210 milhões de árvores localizado em São Paulo e no Triângulo Mineiro. Desse patrimônio, o Estado de São Paulo é responsável por $86 \%$ de laranja, $94 \%$ de limão e $80 \%$ de tangerina. Entretanto, a soberania da citricultura paulista vem sendo constantemente ameaçada por graves problemas fitossanitários. Um dos mais severos é o Cancro Cítrico, causado pela bactéria Xanthomonas axonopodis pv. citri Vauterin et al. (Xac).

Presente no Estado desde 1957 (Rossetti, 1977), o Cancro Cítrico mantevese sobre relativo controle através da ação da Campanha Nacional de Erradicação. Em 1997, uma severa mudança no comportamento da doença foi observada. $O$ número de focos da doença que se manteve baixo por décadas, aumentou drasticamente de 45 focos em 1995 para 4180 em 1999 (Fundecitrus, 2003). O padrão espacial do Cancro Cítrico, caracterizado como fortemente agregado, passou para padrões de agregação intermediários e distribuição ao acaso (Bergamin Filho et al., 2001).

A mudança do comportamento do Cancro Cítrico foi associada com a introdução, em 1996, do microlepidóptero Phyllocnistis citrella Stainton, conhecido como 'Lagarta Minadora dos Citros' (LMC). A lagarta infesta folhas de citros, 
formando galerias no limbo foliar. Folhas com injúrias de LMC apresentam maior incidência de Cancro do que folhas não infestadas (Sohi \& Sandhu, 1968).

O conhecimento da estrutura e do comportamento do patossistema 'CitrusXaC-LMC', vigente hoje em São Paulo, é pré-requisito para a definição de uma estratégia racional de erradicação e/ou de manejo econômico do Cancro Cítrico adaptada ao Estado.

O presente trabalho pretendeu compreender a interação 'Citrus-Xac-LMC' nos componentes monocíclicos (período de incubação, severidade da doença, densidade e tamanho de lesão) do Cancro Cítrico em Limão Tahiti (Citrus latifolia TANAKA), sob condições controladas. O trabalho teve por objetivo avaliar: (i) 0 efeito da concentração de inóculo e da via de penetração por estômato (folha intacta), por ferimento (folha com ferimento mecânico) e por injúria de LMC (folha com injúria de $L M C$ ) na infecção de Xac; (ii) a influência da idade do ferimento (folha com ferimento), da injúria de LMC (folha com injúria de LMC) e da folha intacta na severidade do Cancro Cítrico; (iii) o efeito da temperatura e do período de molhamento foliar no desenvolvimento do Cancro. 


\section{REVISÃO DE LITERATURA}

\subsection{Citricultura Paulista, aspecto econômico}

Na safra 2001/2002, a produção mundial de citros foi de 48,3 milhões de toneladas (Agrianual, 2003). O Brasil foi responsável por 37\% desse montante, mantendo-se na posição de líder, seguido pelos EUA com $24 \%$.

O Sudeste do Brasil é a principal região produtora de citros (mais de $85 \%$ da produção nacional), com um patrimônio representado por um parque de mais de 210 milhões de árvores localizado em São Paulo e no Triângulo Mineiro. O Estado de São Paulo é o maior produtor de citros, responsável por $85,6 \%$ de laranja, 94\% de limão e $79,6 \%$ de tangerina da produção na região.

A citricultura é a principal fonte econômica de 330 municípios paulistas e do Triângulo Mineiro, gerando mais de 420 mil empregos diretos e movimentando US\$ 7 bilhões anualmente, além de gerar ao país US $\$ 1,2$ bilhões ao ano em exportações (Souza, 2000).

A produção de limão, principalmente de Limão Tahiti (ou Lima Ácida Tahiti), provém quase exclusivamente do Estado de São Paulo. Os frutos de Tahiti são destinados quase que exclusivamente para atender a demanda do mercado interno e a indústria de suco. Somente uma pequena parte é exporta. No ano de 2001, a 
"pequena parte" exportada correspondeu a 15 mil toneladas de limão 'in natura', sendo os Países Baixos os principais importadores (62\%) (Agrianual, 2003).

\subsection{Importância do Cancro Cítrico e sua origem}

O Cancro Cítrico é um dos mais graves problemas fitossanitários da citricultura atual. A bacteria Xac causa lesões necróticas típicas nas folhas, galhos e frutos. Severas infecções nos citros causam desfolhação, queda prematura de frutos, seca de ponteiros e declínio generalizado da planta. Em adição à debilitação do citros e à perda de qualidade e quantidade de frutos, a doença causa restrições na comercialização nacional $e$ internacional de mudas e frutos 'in natura' para regiões livres do patógeno.

A mais antiga constatação do Cancro Cítrico foi feita por Fawcett \& Jenkins (1933) em folhas herbarizadas de Citrus medica coletadas na Índia entre 1827 e 1831. Entretanto, a doença foi descrita pela primeira vez em 1915, quando se deu a sua introdução nos EUA.

O Cancro Cítrico é originário do Sudoeste da Ásia, mesmo centro de origem dos citros e sua disseminação, principalmente pelo transporte de mudas, atingiu vários regiões do mundo, como Japão, Austrália, Nova Zelândia, Ilhas do Pacífico, Sul e Centro da África, Sul da América e EUA. Em muitos países, a doença ocorre endemicamente, como na Argentina, Paraguai e Uruguai (Leite Jr., 1990). O sucesso da erradicação de Xac foi mérito de poucos países, como Austrália, África do Sul e Nova Zelândia. Nos EUA, o Cancro Cítrico, apesar ter sido erradicado em 1933 
(Dopson, 1964), foi reintroduzido na Flórida em Tampa Bay no ano de 1986 e na zona urbana de Miami em 1995 (Schubert et al., 2001).

No Brasil, sua primeira constatação deu-se no município paulista de Presidente Prudente, em 1957 (Rossetti, 1977; Rossetti et al., 1981). No mesmo ano, foi encontrado também no Estado do Paraná, no município de Lupionópolis (Leite Jr, 1990). Na tentativa de conter e erradicar a doença do parque citrícola brasileiro, foi criada a Campanha Nacional de Erradicação do Cancro Cítrico. Abandonada, exceto pelo Estado de São Paulo, que até hoje ainda prática a erradicação, a Xac foi disseminada para outras regiões e estados, estabelecendose nos Estados de Paraná, Santa Catarina, Rio Grande do Sul, Mato Grosso do Sul, Mato Grosso e Minas Gerais (Feichtenberger et al., 1997; Maciel et al., 1998) e recentemente em Roraima (Nascimento et al., 2003).

A campanha de erradicação em São Paulo, apesar de não conseguir eliminar o Cancro Cítrico de seus pomares, permitiu durante várias décadas um relativo controle da doença e impediu a sua introdução na área nobre da citricultura paulista.

O programa de erradicação, segundo a Fundecitrus (2003), gasta mais de 300 mil reais por ano. Apesar de controvérsias, o programa ainda se mostra eficiente no controle da doença mesmo após o sinergismo da interação Xac e Lagarta Minadora dos Citros (LMC), Phyllocnistis citrella. Introduzida no Brasil em 1996, a LMC foi associada com o aumento drástico da incidência do Cancro Cítrico, de 45 focos em 1996 para cerca de 4480 focos em 1999 (Fundecitrus, 2003). Nesse ano, 0,70\% dos talhões dos pomares paulistas apresentavam a doença (Barbosa \& Fernandes, 1999). Porém, em 2000, a incidência caiu para 0,20\%, e hoje está em torno de 0,22\% dos talhões (Fundecitrus, 2003). Provavelmente a erradicação continua a ser uma estratégia viável de controle do Cancro Cítrico. 
A bactéria Xac é um dos poucos patógenos cuja erradicação se mostra eficiente. Conforme mencionado por Schubert et al. (2001), essa eficiência está relacionada com suas características patogênicas, como diagnose fácil e rápida (sintomas típicos), disseminação relativamente lenta, ausência de vetores, hospedeiros restritos, alto valor econômico da cultura e não competência do patógeno em sobreviver por longo período na ausência de hospedeiro.

\subsection{Etiologia}

Xanthomonas axonopodis pv. citri Vauterin et al. (Bacteria, Proteobacteria, Subdivisão Gamma, Xanthomodales) pertence ao grupo das Xanthomonas, apresenta reação gram-negativa, respiração aeróbica, formato baciliforme e motilidade por um flagelo polar (monotríquia). Polissacarídeos extracelulares são produzidos pelas células bacterianas, ajudando na sua dispersão e sobrevivênvia (Goto \& Hyodo, 1985).

A bactéria Xac cresce na maioria dos meios usados em laboratório e é facilmente isolada de tecido cítrico infectado. Colônias da bactéria são visíveis em meio de cultura com ágar após 2-3 dias de incubação a $28^{\circ} \mathrm{C}$ (Rossetti et al., 1981).

Devido à existência de outros patovares e variantes, $X$. axonopodis patogênicas ao gênero Citrus foram classificados em cinco grupos, como consta na literatura, diferenciados basicamente pelo hospedeiro e sintomatologia (Gabriel et al., 1989; Feichtenberger et al., 1997): (i) Cancro Cítrico Asiático ou Cancrose A, causado por Xanthomonas axonopodis pv. citri, afeta grande número de espécies da família Rutacea e está disseminada em muitas regiões da Ásia, África, Oceania e 
América, sendo a mais importante e severa; (ii) Cancro Cítrico B ou Cancrose B, causada pela estirpe B de Xanthomonas axonopodis pv. aurantifolii, afeta menos hospedeiros que a Xac, sendo mais agressivo em limões verdadeiros (Citrus limon) e lima ácida Galego (Citrus aurantifolia), estando restrita à Argentina, Paraguai e Uruguai; (iii) Cancrose do Limoeiro Galego ou cancrose $C$, causada pela estirpe $C$ de Xanthomonas axonopodis pv. aurantifolii, afeta principalmente a lima ácida Galego (Citrus aurantifolia), restrita a algumas regiões do Estado de São Paulo; (iv) Cancrose D, causada pela estirpe D de Xanthomonas axonopodis pv. aurantifolii (não está muito bem caracterizada), restrito à lima ácida Galego (Citrus aurantifolia) e ocorre no México; e (v) Mancha bacteriana dos Citros, causada por Xanthomonas axonopodis pv. citrumelo, afeta principalmente porta-enxertos citrumelos Swingle e ocorre em viveiros da Flórida.

A taxonomia de Xanthomonas apresenta bastante controvérsia, sendo constantemente revisada (Schaad et al., 2000). Foram feitas propostas de reclassificação das estirpes do grupo cancro cítrico como uma nova espécie, Xanthomonas citri (Schaad et. al., 2000; Brunings \& Gabriel, 2003). O nome científico de Xac ainda é aceito e na literatura mundial a doença do patógeno é referida como Cancro Cítrico Asiático, enquanto que no Brasil, por ser a principal e a mais severa do grupo cancro, é denominado como Cancro Cítrico.

O gênero Citros apresenta espécies, híbridos e cultivares com ampla variabilidade nos níveis de resistência ao Cancro Cítrico, sendo considerados de resistentes a altamente suscetíveis. Diversos trabalhos relatam o nível de resistência entre diversas cultivares (Goto, 1992; Gottwald et al., 1993; Graham, 2001; Leite \& Mohan, 1984; Zubrzycki \& Zubrzycki, 1981; Koizumi \& Kuhara, 1982) entretanto, os critérios de avaliações variam, havendo algumas informações contraditórias. Como exemplo, a Tangerina Ponkan e o Limão Tahiti são 
considerados resistentes a Xac, segundo Leite \& Mohan (1984), enquanto que, no artigo de Graham (2001), a Ponkan é considerada resistente e o Limão Tahiti, suscetível.

\subsection{Lagarta Minadora dos Citros e seu sinergismo com $X$. axonopodis pv. citri}

A Lagarta Minadora dos Citros (LMC) é um jovem imaturo de Phyllocnistis citrella, relatado por Stainton em 1856 a partir espécimes coletados da Índia. Esta praga ataca principalmente plantas da família Rutácea, sendo atraída principalmente por plantas do gênero Citrus (Heppner, 1993; Argov \& Rossler, 1996). O adulto não causa danos. Somente durante a fase imatura que $P$. citrella ganha importância para a citricultura.

A LMC alimenta-se do tecido paliçádico de folhas novas, formando galerias (minas) entre a epiderme e o parênquima. As folhas infestadas se enrolam e tornam-se cloróticas ou até necróticas, reduzindo a sua capacidade fotossintética. $\mathrm{Na}$ planta, ocorre queda prematura de folhas, redução no crescimento e no desenvolvimento de brotações, assim como perdas na produtividade (Clausen, 1931; Huang \& Li, 1989; Wilson, 1991; Heppner, 1993; Argov \& Rossler, 1996; Peña et al., 1996; Moraes et al., 1999; Nascimento et al. 2000). Entretanto, os danos indiretos são os mais preocupantes pois as galerias abertas pela minadora expõem o mesófilo foliar que pode servir de entrada para microorganismos, como a Xac e fungos saprófitas, como Alternaria spp. e Paecilomyces spp (Sohi \& Sandhu, 1968; Cook, 1988). 
Originária do Sudeste da Ásia, a LMC permaneceu sem expansão até o ano de 1986, restringindo-se aos países do leste da África, Ásia, Austrália, China, Índia, Japão, Filipinas, Tailândia, Nova Guiné e Ilhas do Pacífico. Em 1993 foi detectada nos pomares da Flórida, EUA, e posteriormente no México e Honduras. Nos três anos seguintes, a LMC estava presente no Caribe, América Central e nos países do norte da América do Sul (Knapp et al., 1993; Peña et al., 1996; Perioto, 1997).

No Brasil, a LMC foi constada pela primeira vez em março de 1996, na região de Limeira, no sul do Estado de São Paulo (Feichtenberger \& Raga, 1996). No final do mesmo ano, a praga foi encontrada no Piauí, no sul de Minas Gerais, a oeste do Paraná e de Santa Catarina e no Rio Grande do Sul, estando atualmente em todas as regiões citrícola do país (Chiaradia \& Milanez, 1997; Lolato \& Moraes, 1997; Lopes et al., 1997; Lima \& Aguiar, 1997; Moreira et al., 1997; Silva et al., 1997; Rodrigues et al., 1998; Moraes et al, 1999). Na Argentina, a LMC foi encontrada no final de 1996 e dispersou também rapidamente por todo o país (Sacarias \& Canales, 1999).

Da família Gracillariidae, P. citrella são microlepidópteros apresentando envergadura em torno de $4 \mathrm{~mm}$. As asas anteriores são cobertas com escamas de coloração branca e prata brilhante, com manchas pretas e marrom-amareladas dispersas, e uma mancha preta bem característica na região apical da asa anterior, sendo que as asas posteriores e o corpo são brancos.

A taxa de crescimento da população de $P$. citrella pode apresentar de 5 a 13 gerações em um ano. Os adultos apresentam longevidade de 1 a 7,5 e 1 a 22,5 dias, para machos e fêmeas, respectivamente. As fêmeas durante esse período ovipositam entre 21 a 28 ovos, sendo o potencial de ovoposição influenciado pela variedade da planta hospedeira (Clausen, 1931; Radke \& Kandalkar, 1987; Batra et al., 1988; Huang et al., 1989; Wilson, 1991). 
Chagas e Parra (2000) desenvolveram uma metodologia de criação de $P$. citrella em laboratório. Plantas de Limão Cravo (Citrus limonia L. Osbeck) com 25 a $30 \mathrm{~cm}$ de altura, cultivadas em tubetes de $20 \mathrm{~cm}$ por $1,5 \mathrm{~cm}$, são podadas a $1 / 3$ do seu ápice. As plantas apresentando brotações recém emergidas, com cerca de $6 \mathrm{~mm}$ de folhas tenras, são colocadas para postura em gaiola entomológica com casais de P. citrella, na proporção de um inseto para cada três plantas. $O$ tempo de exposição é de no máximo 3 dias, resultando mais de $70 \%$ das plantas infestadas com ovos. 0 período de incubação do ovo e a duração dos ínstares levam em consideração as temperaturas testadas $\left(18,20,22,25,28,30\right.$ e $\left.32 \pm 1^{\circ} \mathrm{C}\right)$, nas condições de $60 \%$ UR e fotofase de $14 \mathrm{~h}$. Folhas contendo pupas são depositadas em câmaras de emergência. Após a emergência, os adultos são liberados no interior das gaiolas de postura.

A ovoposição é feita preferencialmente (acima de $80 \%$ dos ovos) na superfície abaxial das folhas. Os ovos concentram-se, em mais de $80 \%$, nas porções mediana e apical das folhas e principalmente $(72,8 \%)$ na nervura principal. Em casos de alta infestação, é comum encontrar ovos nos dois lados do limbo foliar (Chagas \& Parra, 2000).

Os ovos de P. citrella são de difícil visualização a olho nu, sendo convexos, translúcidos e medindo $0,3 \times 0,2 \mathrm{~mm}$. Tornam-se mais visíveis próximos à eclosão, quando assumem coloração amarelo opaco (Batra et al., 1988; Garijo \& Garcia, 1994; Heppner, 1995; Alba, 1996). O tempo de duração do estádio ovo é de 2,1 dias, a $25^{\circ} \mathrm{C}$ (Chagas \& Parra, 2000).

Após a eclosão, a LMC penetra rapidamente no tecido foliar iniciando a construção das minas típicas em forma de serpentina e de coloração prateada, tornando as folhas retorcidas no final do ataque. Normalmente, apenas uma lagarta se desenvolve por folha, podendo ocorrer de 2 a 3 lagartas/folha em altas 
infestações. P. citrella apresenta quatro fases larvais: $1^{\circ}$ instar, $2^{\circ}$ instar, $3^{\circ}$ instar e $4^{\circ}$ ínstar, e a duração de cada fase é de 1,5; 1,7; 1,6 e 0,8 dia respectivamente, a $25^{\circ} \mathrm{C}$ (Chagas \& Parra, 2000).

A pupação ocorre dentro da mina, em uma câmara pupal, localizada na maioria das vezes à margem da folha, formada pelo enrolamento de sua borda, unida por fios de seda. A fase pupa, a $25^{\circ} \mathrm{C}$, dura cerca de 8,1 dias (Chagas \& Parra,2000).

Conforme descrito por Chagas \& Parra (2000), os estádios de desenvolvimento da LMC são afetadas pela temperatura. As fases de ovo a pupa podem variar de 32,8 e 11,4 dias nas temperaturas de $18^{\circ} \mathrm{C}$ e $32^{\circ} \mathrm{C}$, respectivamente, em condições de laboratório, com 60\% UR e fotofase de 14 horas. Em condições de campo, Paiva et al. (1998) também relataram que baixas temperaturas aumentam a duração do ciclo larval, 16 dias no inverno, e o inverso em temperaturas mais elevadas, 7 dias no verão.

Embora $P$. citrella tenha preferência por folhas novas, as lagartas podem se desenvolver no interior do pecíolo das brotações (Hutson \& Pinto, 1934; Sponagel \& Díaz, 1994) ou até mesmo em frutos (Sponagel \& Díaz, 1994; Heppner, 1995).

Como mencionado anteriormente, os danos causados à planta cítrica dependem do nível de infestação da praga, podendo comprometer a fotossíntese, causar queda prematura das folhas e impedir o desenvolvimento das brotações (Clausen, 1931; Badawy, 1967; Heppner, 1993; Prates et al., 1996). Indiretamente, 0 maior dano da praga estaria relacionado com a sua interação sinérgica com a Xac, contribuindo para a penetração e desenvolvimento da bactéria através dos tecidos lesionados.

Com o surgimento da LMC houve um considerável aumento na severidade do Cancro Cítrico e mudança do comportamento da doença em pomares do Paraná, Rio 
Grande do Sul e São Paulo, assim como também na Flórida, EUA (Gottwald et al., 1997; Rodrigues et al., 1998; Bergamin Filho et al., 2001).

Levantamentos realizados em pomares de citros com Xac em outros países têm demonstrado significante associação entre injúrias de LMC e incidência de Cancro Cítrico. Folhas com galerias de LMC apresentam incidência e número de lesões de Cancro maiores do que em folhas livres de LMC (Sohi \& Sandhu, 1968; Cook, 1988; Heppner, 1993).

A LMC pode interagir com a Xac por dois caminhos, como sugerido por diversos autores (Gottwald \& Garnsey, 1991; Gottwald \& Graham, 1992; Gottwald et al., 1993 e Gottwald et al., 1997). O primeiro, durante o processo de alimentação e formação das galerias da LMC, o mesófilo da folha é exposto e a Xac, quando em contanto com a injúria da LMC, penetra diretamente pelo mesófilo, causando infecção na folha. No segundo, a LMC pode entrar em contato com a bactéria e a mesma ser transportada durante o processo de construção da mina, disseminando a Xac por todo interior da galeria.

Indícios de aquisição de Xac pelo adulto de P. citrella e, conseqüentemente, a transmissão da bactéria pela lagarta na folha infestada, não foi, até o presente momento, constatado (Chagas et al., 2001).

\subsection{Epidemiologia do Cancro Cítrico}

A principal fonte de inóculo de $X$. axonopodis pv. citri são plantas de citros infectadas pela bactéria, que sobrevive de uma estação para outra em lesões nos ramos e nas folhas da planta hospedeira. A viabilidade das lesões dependerá da 
longevidade das células hospedeiras. Lesões de cancro em ramos podem ser fontes de inóculo durante vários anos. Na ausência de citros, a Xac possui um período relativamente curto de sobrevivência. Em materiais de metal, de plástico, tecido ou madeira, a bactéria sobrevive no máximo até 72 horas (Graham et al., 2000). No solo, Xac pode persistir por meses na rizosfera de gramíneas (Goto et al., 1975; Pereira et al., 1976 e 1978) e de 1 a 2 meses em folhas e frutos em decomposição (Graham et al., 1989; Leite JR., 1990). Livre, a bactéria tem pouca possibilidade de sobreviver devido ao antagonismo e competição dos microorganismos saprófitas.

Em condições de alta umidade, as lesões de Cancro Cítrico exsudam bactérias na superfície. Em lesões novas, na presença de filme de água, a exsudação é instantânea, liberando de $10^{4}$ a $10^{5} \mathrm{UFC} / \mathrm{mL}$. Com o tempo, as lesões tornam-se suberizadas e a liberação de Xac ocorre lentamente (Timmer et al., 1991).

As gotas de água quando se chocam com lesões de Xac dispersam as bactérias, suspensas em gotículas, para ramos e plantas ao redor. Na presença de vento, as gotículas podem alcançar maiores distâncias, de até $15 \mathrm{~m}$ (Gottwald et al., 1988; Gottwald \& Timmer, 1995). A concentração bacteriana nas gotículas provenientes de folhas com lesões podem conter de $10^{5}$ a $10^{8} \mathrm{UFC} / \mathrm{mL}$ (Goto, 1962; Stall et al., 1980). Na ocorrência simultânea de chuva e vento, aerossóis podem ser formados, levando células bacterianas a longas distâncias. No Sudeste brasileiro, 0 verão favorece a disseminação e a severidade do Cancro Cítrico, devido a altas temperaturas associadas com chuvas intensas e ventos durante o fluxo de brotações dos pomares (Palazzo et al., 1984)

Como ocorre em outras bactérias, a Xac penetra no hospedeiro por aberturas naturais, principalmente estômatos, e por ferimentos causados por espinhos, grão de areia, pelo homem ou por insetos. A face abaxial de folhas de citros é muito mais suscetível para penetração via estômato. A diferença na 
suscetibilidade entre as faces adaxial e abaxial está em razão da maior densidade de estômatos na face abaxial (McLean, 1921; Graham et al., 1992a). A concentração do inóculo para causar infecção varia de acordo com a via de penetração, sendo suficiente às concentrações de $10^{4}$ a $10^{5} \mathrm{UFC} / \mathrm{mL}$ e $10^{2} \mathrm{UFC} / \mathrm{mL}$ para infecções via estômato e ferimento, respectivamente (Goodman, 1982; Zubrzycki \& Zubrzycki, 1987). Porém, duas células de Xac são suficientes para causar infecção quando inoculadas no interior da câmara sub-estomática (Gottwald \& Graham, 1992).

A colonização por Xac é restrita à área infectada. As lesões são formadas por hipertrofia e hiperplasia de células do hospedeiro, resultando em calos salientes sobre a superfície foliar. Geralmente halos cloróticos contornam as lesões. A taxa de expansão de lesões em folhas é aproximadamente de $1 \mathrm{~mm}$ por mês até 6 a 8 meses. Em ferimento mecânico (agulha histológica) as lesões crescem rapidamente até os 30 dias após a inoculação. Dos 30 aos 40 dias, as lesões expandem-se lentamente e a partir dos 40 dias a taxa de expansão decresce a próximo de zero (Graham et al., 1990)

Tecidos foliares em expansão, ou seja, folhas jovens, são mais suscetiveis que folhas completamente expandidas (maduras). $O$ período de suscetibilidade dos frutos é entre 60 a 90 dias após a sua formação (Lee, 1922; Stall et al., 1982; Gottwald \& Grahan, 1992; Graham et al., 1992b)

A suscetibilidade ao Cancro Cítrico em relação à idade da folha, segundo Stall et al. (1982), está associada ao desenvolvimento de resistência do mesófilo à multiplicação de Xac em folhas maduras. Os autores notaram que é possível distinguir níveis de resistência entre cultivares inoculados por infiltração em folhas com 14 a 21 dias de idade, mas não em folhas maduras.

Cultivares resistentes ao cancro, como Mandarin, comportam-se como suscetíveis quando inoculadas via ferimento. Aparentemente, a suscetibilidade do 
mesófilo da folha é semelhante entre cultivares de citros resistentes e suscetíveis, quando inoculadas via ferimento, como demonstrado por diversos autores (Lee, 1922; Peltier, 1924; Koizumi, 1981; Leite \& Mohan, 1984; Agostini et al., 1985; Matsumoto \& Okudai, 1988; Gottwald et al., 1993). O ferimento permite o contato direto da bactéria com o mesófilo da folha, quebrando qualquer eventual resistência estrutural da planta à infecção bacteriana (McLean \& Lee, 1921).

McLean (1921) propôs que as características do estômato, que diferem entre grapefruit (altamente suscetível) e Mandarim (moderadamente resistente), são responsáveis pela variação genotípica na resistência ao Cancro Cítrico.

Gottwald \& Graham (1992) observaram que a pressão requerida para obter penetração bacteriana aumentou drasticamente em folhas com $2 / 3$ da sua expansão (folhas jovens) para completamente expandidas (folha madura). Os autores propõem que as características das folhas que mudam com os estádios de expansão devem afetar a maneira com que a bactéria ganha o interior do mesófilo.

No trabalho de Graham et al. (1992a), a comparação de estômatos das cultivares Duncan grapefruit (altamente suscetível) e Cleópatra Mandarin (moderadamente resistente) por microscopia eletrônica de varredura mostrou pouca diferença entre as cultivares na morfologia de ante-câmaras e área de abertura dos estômatos, ao contrário do sugerido por McLean (1921). Os estômatos de folhas com $2 / 3$ de expansão e completamente expandidas também não apresentaram diferença significativa na estrutura estomatal. Os autores propõem que as características da folha que influenciam na infiltração da água e no enxarcamento do tecido foliar são mais importantes para o sucesso da penetração da bactéria do que as diferenças genotípicas em densidade e estrutura de estômatos. Os autores também observaram um rápido desenvolvimento de cutícula e cera ao redor das ante-câmaras de estômatos em folhas expandidas em relação à 
folha em expansão, coincidindo com o aumento considerável na resistência de folhas de Duncan grapefruit para o encharcamento e penetração bacteriana.

As diferenças observadas entre cultivares resistentes e suscetíveis devemse ao número de lesões e principalmente à população bacteriana emergente das lesões. Cultivares suscetíveis com número de lesões semelhante ou menor que cultivares resistentes podem conter lesões com uma população bacteriana significativamente superior (Graham et al., 1990).

A frequiência, tamanho e duração de folhas tenras também são fatores que atribuem níveis de suscetibilidade para Xac em condições de campo. Assim, cultivares menos vigorosas ou cuja folhagem atingem a maturidade mais rapidamente se comportam como resistentes em relação a outras mais vigorosas (Koizumi \& Kuhara, 1982; Agostini et al., 1985; Graham et al., 1992a)

Em relação ao comportamento epidemiológico do Cancro Cítrico em condições naturais de epidemia, existem poucos estudos devido às restrições dos grandes países produtores a pesquisas de campo com a doença em seu território (Amorim \& Bergamin Filho, 2001). Os aspectos temporal e espacial de epidemias de Cancro Cítrico foram investigados na Argentina, na década passada, em viveiros de mudas (Gottwald et al., 1988). Os resultados conseguidos, apesar de únicos, guardam pouca relação com o que acontece em plantios comerciais, especialmente quando a disseminação da bactéria é considerada. Nos trabalhos de Danos et al. (1984), Gottwald et al. (1992), Gottwald \& Timmer (1995) e Pruvost et al. (1999) também não são esclarecedores. Informações precisas sobre esse aspecto do ciclo da doença são indispensáveis para que uma estratégia racional de controle da doença possa ser proposta, seja para tornar a erradicação mais eficiente, seja para tornar o convívio com o patógeno menos oneroso ao produtor (Amorim \& Bergamin Filho, 2001). 
A partir de 1997, constatou-se dramática mudança no número de focos e no padrão espacial do Cancro Cítrico em São Paulo. O número de focos da doença aumentou drasticamente de 45 focos em 1995 para 4180 em 1999 (Fundecitrus, 2003). A acentuada agregação de plantas afetadas, típica para os anos anteriores de 1996, deu lugar a padrões de agregação intermediários e distribuição ao acaso, como demonstrado pela análise espacial em diferentes regiões do Estado de São Paulo (Bergamin Filho et al., 2001).

A dramática mudança no padrão espacial do Cancro Cítrico foi associada com a introdução, em 1996, de uma nova praga na citricultura brasileira, Phyllocnistis citrella (Lagarta Minadora dos Citros).

A LMC causa grandes injúrias nas folhas jovens da planta cítrica, podendo cobrir toda a área foliar (Rodrigues et al., 1998). Os ferimentos mais severos, como aqueles produzidos por espinhos ou vento, cicatrizam em um ou dois dias (Goto, 1990) enquanto que os provocados pela LMC permitem a penetração do patógeno durante um período de 10 a 14 dias. Além disso, as injúrias de LMC transformam os aerossóis em mecanismos eficientes de disseminação da doença. Na coincidência do fluxo de brotação do citros com a presença da minadora e de aerossóis, células bacterianas capazes de causar infecção poderiam alcançar distâncias superiores a um quilômetro (Koizumi et al., 1996).

Em hospedeiros moderadamente resistentes, como Mandarin, a infecção de Xac ocorre freqüentemente em sinergismo com a LMC. Segundo alguns autores, a LMC dissemina a Xac, carregando a bactéria em seu corpo, nas galerias construída em folhas infestadas, ocasionando numerosas infecções no mesófilo da folha (Gottwald \& Garnsey, 1991; Gottwald \& Graham, 1992; Gottwald et al., 1993; Gottwald et al., 1997). 
O patossistema que ocorre hoje no Brasil, Citros-Xac-LMC, tem características epidemiológicas diferentes daquele patossistema que existiu no país de 1957 a 1996, Citros-Xac (Bergamin et al., 2001).

\subsection{Controle do Cancro Cítrico}

As principais medidas de controle do Cancro Cítrico são a exclusão e a erradicação. Essas medidas de controle foram suficientes para retardar consideravelmente a introdução da doença nas principais regiões produtoras do Estado de São Paulo (Feichtenberger et al., 1997).

As medidas de exclusão envolvem a restrição de acesso e fiscalização à circulação de pessoas, veículos e implementos em pomares, principalmente provenientes de outras propriedades citrícolas. Veículos, implementos e materiais de colheita devem ser desinfestados antes de adentrarem os pomares. Construção de 'bins' na entrada das propriedades para armazenamento dos frutos colhidos, evitando a circulação de pessoas e veículos estranhos no pomar é uma recomendação importante. Aquisição de mudas sadias e certificadas também é recomendada.

A implantação de quebra-ventos arbóreos reduz a velocidade do vento dentro do pomar, proporcionando condições menos propícias à disseminação da bactéria e formação de aerossóis, assim como diminui os ferimentos provocados pelo vento (Leite Jr., 1990; Gottwald \& Timmer, 1995).

No Paraná, onde a doença é endêmica, as medidas preventivas incluem pulverização com bactericida cúprico para proteção de folhagens e frutos novos e o 
controle da LMC com inseticida ou parasitóides (Leite Jr., 1990; Fundecitrus, 2003).

Alguns parasitóides têm demonstrado potencial de utilização para o controle da $L M C$, registrando-se, em determinadas regiões do mundo, 54,4\% de parasitismo natural (Chen \& Le, 1986). Como exemplo, o encirtídeo Ageniaspis citricla, originário da Ásia, vem sendo usado no controle da LMC no Brasil, com comprovado sucesso em introduções realizadas na Austrália (Neake et al., 1995), em Israel (Argov \& Rossler, 1996) e nos EUA (Hoy et al., 1997).

Em caso de suspeita de Cancro Cítrico, a propriedade deve ser inspecionada três vezes consecutivamente por três equipes diferentes, em todas as plantas do talhão infestado. Se o número de plantas contaminadas for superior a $0,5 \%$, em relação ao total do talhão, todas as plantas desse talhão são eliminadas. Se o número for inferior a 0,5\%, são erradicadas apenas as árvores contidas em um raio de 30 metros a partir do foco. A área erradicada deve ficar por dois anos sem qualquer planta do gênero Citrus (Fundecitrus, 2003). 


\section{MATERIAL \& MÉTODOS}

\subsection{Aquisição de mudas}

Como o limoeiro Tahiti não produz frutos com sementes, as mudas de Limão Tahiti utilizadas no experimento foram obtidas por micro-enxertia em Poncirus trifoliata cultivado em tubetes de $20 \mathrm{~cm}$ de altura por $1,5 \mathrm{~cm}$ de diâmetro, contendo substrato de vermiculita e composto vegetal. $O$ tempo gasto para produzir as mudas foi de 3 a 4 meses e envolveram as etapas de semeadura de $P$. trifoliata, enxertia e obtenção de ramos de Tahiti com 10 a $15 \mathrm{~cm}$ de comprimento.

A produção de mudas em tubetes possibilitou a condução dos experimentos em salas fechadas e respeitando as normas de segurança fitossanitária. Grades de tubos de ensaio de 40 lugares foram utilizadas como suporte para as plantas em tubetes.

As mudas com 20 a $25 \mathrm{~cm}$ de altura foram podadas a, aproximadamente, $1 / 3$ de seu ápice e mantidas em casa de vegetação com sistema de irrigação por microaspersão no campo experimental do Setor de Entomologia/ESALQ. Após 20 dias da poda, as brotações emergentes das plantas estavam aptas a serem empregadas nos experimentos. 


\subsection{Obtenção de inóculo}

$O$ isolado de $X$. axonopodis pv. citri (estirpe IBSBF 1421), utilizado em todos os experimentos, foi fornecido pelo Dr. Júlio Rodrigues Neto do Laboratório de Bacteriologia Vegetal do Instituto Biológico de São Paulo, Campinas/SP.

Para manutenção e preservação da viabilidade da bactéria foi empregado o método de Castellani (1939) para o armazenamento do inóculo a curto período (máximo de 6 meses) e o método de congelamento a $-80^{\circ} \mathrm{C}$ em glicerol $10 \%$ (Quadling, 1960), preservando o inóculo durante o período de condução do experimento.

A concentração da suspensão bacteriana foi ajustada por turbidimetria, em espectrofotômetro a $480 \mathrm{~nm}$, determinando a concentração de $3,4 \times 10^{8} \mathrm{ufc} / \mathrm{mL}$ para transmitância de $51,2 \%$.

Para obtenção do inóculo, a cultura bacteriana, cultivada em meio NA por 48 horas a $26-28^{\circ} \mathrm{C}$, foi diluída em água destilada esterilizada e a suspensão calibrada na concentração desejada, com auxílio do colorímetro.

\subsection{Segurança fitossanitária}

O Cancro Cítrico por ser uma doença quarentenária e sujeita a erradicção no Estado de São Paulo, medidas de segurança foram adotadas para a condução desse trabalho. Todos os experimentos foram realizados em salas fechadas, sem janelas, destinadas exclusivamente ao projeto. No interior da sala foi colocada uma ante- 
sala com tela anti-afídeos e bandeja com amônio quaternário para a desinfestação da sola dos calçados, de modo a evitar riscos de contaminação e/ou disseminação da bactéria do Cancro Cítrico para outras áreas. O acesso à sala foi estritamente restrito às pessoas vinculadas ao projeto.

Durante a condução dos experimentos, todos os materiais utilizados, como vidrarias e mudas descartadas no final das avaliações foram esterilizados via autoclave, conforme as normas de segurança fitossanitária.

\subsection{Mudas com Lagarta Minadora dos Citros}

Nos experimentos onde avaliou-se a interação $X$. axonopodis pv. citri e a Lagarta Minadora dos Citros, mudas em tubetes contendo folhas infestadas pela lagarta foram utilizadas.

Para obtenção das mudas infestadas com LMC, a metodologia desenvolvida por Chagas \& Parra (2000) foi adaptada e empregada ao Limão Tahiti.

Plantas de Limão Tahiti com 20 a 25 cm, cultivadas em tubetes, foram podadas e mantidas em casa de vegetação. As plantas, apresentando brotações novas, com folhas tenras de 6 a $10 \mathrm{~mm}$ de comprimento, foram transferidas para gaiola entomológica contendo casais de $P$. citrella, em sala climatizada a temperatura de $25 \pm 1^{\circ} \mathrm{C}, 60 \pm 10 \%$ UR e fotofase de $14 \mathrm{~h}$. Após período de dois dias, os limões foram retirados da gaiola e as plantas com ovos de LMC separadas para serem utilizadas nos experimentos. As etapas da obtenção de Limão Tahiti com LMC estão ilustradas na Figura 1. 

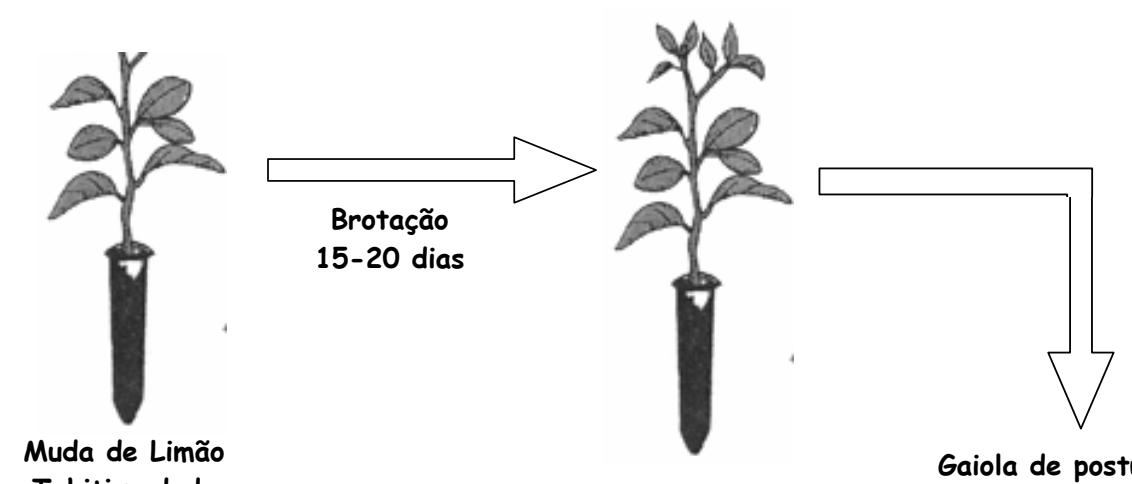

Tahiti podada

Gaiola de postura

(1 inseto : 3 plantas)

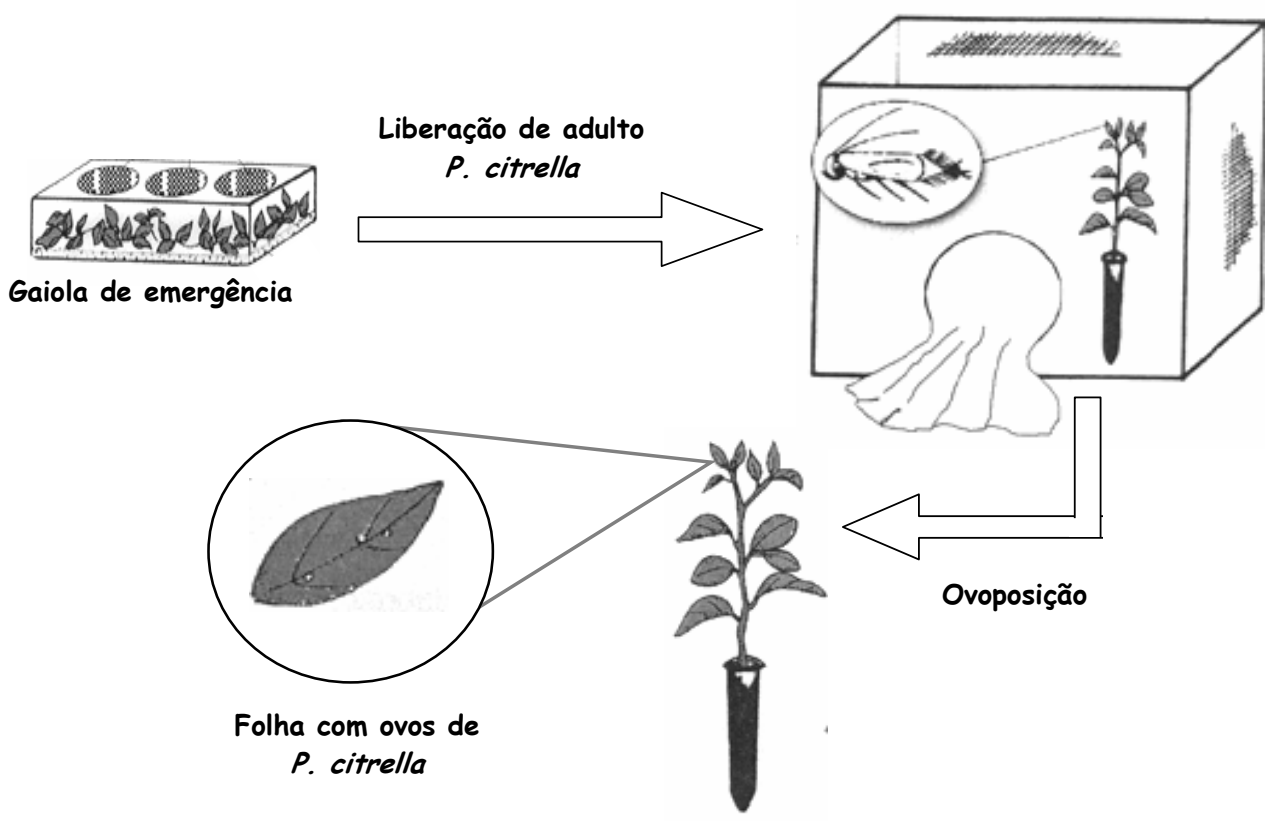

Figura 1 - Esquema de obtenção de mudas de Limão Tahiti com LMC (ilustração adaptada de Chagas \& Parra, 2000) 


\subsection{Via de penetração de $X$. axonopodis pv. citri e a concentração de inóculo na severidade do Cancro Cítrico.}

Para determinar a influência do estômato, do ferimento mecânico e da injúria de $L M C$, assim como a concentração de inóculo na infecção de Xac e na severidade do Cancro Cítrico, foram conduzidos 3 experimentos: $A, B$ e $C$. $O$ delineamento experimental adotado foi inteiramente casualizado, com 8 repetições, sendo cada planta considerada como uma repetição.

No experimento A, para avaliar a via penetração de Xac por estômato, mudas de Limão Tahiti apresentando folhas novas e intactas, ou seja, sem ferimentos, foram inoculadas por aspersão com suspensão bacteriana de Xac nas concentrações de $10^{1}, 10^{2}, 10^{4}$ e $10^{6} \mathrm{UFC} / \mathrm{mL}$. $O$ experimento teve duas repetições no tempo: Experimento 1 (Exp. 1) e Experimento 2 (Exp. 2), com 4 tratamentos (Folha Intacta $\times 4$ concentrações).

No experimento B, para avaliar a via de penetração de Xac por ferimento mecânico, folhas novas de limão foram perfuradas, com agulha histológica, em seis pontos eqüidistantes seguidos por aspersão do inóculo nas concentrações citadas acima. $O$ experimento também foi repetido duas vezes no tempo: Exp. 1 e Exp. 2, com 4 tratamentos (Folha c/ Ferimento $\times 4$ concentrações).

No experimento $C$, para avaliar a via penetração de Xac por injúria de $L M C$, mudas de limão Tahiti com brotações novas foram submetidas à postura de $P$. citrella em gaiola entomológica com casais do microlepdóptero, segundo a metodologia de Chagas \& Parra (2000). Plantas com folhas infestadas com ovos, $1^{\circ}$ ínstar, $3^{\circ}$ ínstar e pupa de LMC foram inoculadas por aspersão nas mesmas concentrações referidas acima. $O$ experimento constou com 16 tratamentos (Folha 
c/ LMC Fase Ovo, Fase $1^{\circ}$ instar, Fase $3^{\circ}$ instar e Fase Pupa $\times 4$ concentrações de inóculo).

A inoculação por aspersão foi obtida com o emprego de bomba a vácuo com pulverizador, inoculando-se os dois lados do limbo da folha, tomando-se o cuidado em enxaguar o pulverizador no ato da troca da concentração de inóculo.

Depois de inoculadas, as plantas foram mantidas em condições de câmara úmida por 96 horas com temperatura controlada a $28^{\circ} \mathrm{C} \pm 2$ e fotofase de 12 horas. As condições de câmara úmida foram obtidas através de gaiolas entomológicas de acrílico vedadas, contendo no seu interior bandejas com água $e$ as paredes umedecidas com borrifador. Após as 96 horas, as plantas foram transferidas para prateleiras, sob as mesmas condições de temperatura e fotofase.

A incidência da doença nas plantas foi avaliada a cada dois dias. No final de 30 dias após a inoculação, nos tratamentos de concentração de $10^{6}$ e de $10^{4}$ UFC/mL, coletou-se uma folha de cada planta com lesões de Cancro Cítrico, totalizando 8 folhas para cada tratamento. 0 mesmo procedimento foi realizado 50 dias após a inoculação para os tratamentos de $10^{2}$ e $10^{1} \mathrm{UFC} / \mathrm{mL}$.

O prazo de trinta dias para coleta das folhas foi determinado através de estudos que demonstram que a taxa de expansão de lesões em folhas é aproximadamente de $1 \mathrm{~mm}$ por mês. Em ferimento mecânico (agulha histológica) as lesões crescem rapidamente até os 30 dias após a inoculação a partir do qual a expansão decresce até próximo de zero aos 40 dias (Graham et al., 1990). A diferença no tempo de coleta das folhas dos tratamentos com alta e baixa concentração foi em função do maior tempo necessário para o surgimento de lesões de Cancro para inóculos em baixas concentrações (Goodman, 1982).

As folhas coletadas foram digitalizadas e a severidade da doença de cada folha determinada por software de quantificação de doença, QUANT v.1.0 (Vale et 
al., 2001). Nos experimentos $B$ e $C$, somente as lesões associadas ao ferimento mecânico e as injúrias de LMC foram mensuradas e a severidade calculada em relação à área foliar.

Com os dados de incidência foram construídas curvas de progresso da doença. O período de incubação, definido como o tempo compreendido entre a deposição do patógeno sobre o hospedeiro (ou inoculação) e o aparecimento dos sintomas visíveis (Vanderplank, 1963; Bergamin Filho \& Amorim, 1996), foi determinado para cada tratamento quando $50 \%$ das plantas apresentavam lesões, obtendo-se o período de incubação médio em dias.

A área abaixo da curva de progresso da doença (AUDPC) para cada tratamento foi calculada por integração trapezoidal:

$$
A U D P C=\sum_{i=1}^{n-1}\left(\frac{X_{i}+X_{i+1}}{2}\right)\left(t_{i+1}-t_{i}\right)
$$

Sendo: $n$ o número de avaliações, $X$ a incidência da doença (em porcentagem) $e\left(t_{i+1}-t_{i}\right)$ o intervalo de tempo entre duas avaliações consecutivas.

Para permitir comparação entre os experimentos, devido à variação do tempo de observação, a variável integral AUDPC foi dividida pelo respectivo período de observação $\left(t_{n}-t_{1}\right)$, sendo marcada com asterisco $\left(^{*}\right)$. Assim a AUDPC $C^{\star}$ a área abaixo da curva de progresso da incidência do Cancro Cítrico estandardizada e pode ser interpretada como a incidência média da doença durante a condução do experimento.

A severidade da doença dos tratamentos nos experimentos $A, B$ e $C$ foi analisada por regressão através do software PROC GLM do SAS (SAS, Inc., 2001) e por regressão não-linear através do software STATISTICA (StatSoft, Inc., 
2001) e a equação da curva foi determinada em razão do coeficiente de determinação $\left(R^{2}\right)$ e do nível significância. A diferença da severidade entre os experimentos $A, B$ e $C$ dentro de um mesmo tratamento, ou seja, mesma concentração de inóculo, foi determinada por contraste ortogonal através do software PROC GLM CONTRAST do SAS, ao nivel de 5\% de significância. O teste F numa análise de variância para tratamentos com mais de um grau de liberdade proporciona informações gerais, relacionadas com o comportamento médio dos tratamentos. A análise por contraste ortogonal é uma técnica que permite fazer desdobramentos dos graus de liberdade de tratamentos para obter informações mais específicas e comparações objetivas, como sugerido por Banzatto \& Kronka (1995).

\subsection{Idade da folha intacta, do ferimento mecânico e da injúria de LMC no desenvolvimento do Cancro Cítrico}

Para avaliar o papel da idade do ferimento mecânico, da injúria de $L M C$ e da folha intacta no desenvolvimento do Cancro Cítrico, foram conduzidos 3 experimentos: $A, B$ e $C . O$ delineamento experimental foi inteiramente casualizado, com 8 repetições, sendo cada planta uma repetição.

No experimento $A$, para analisar a influência da idade da folha intacta na severidade do Cancro Cítrico, folhas de Limão Tahiti com 5 a 7 dias de emissão foram marcadas destacando-se todas as outras folhas da parte superior das plantas. Assim, as plantas continham, na parte superior, somente folhas de 5 a 7 dias de idade. A cada cinco dias, as plantas foram inoculadas por aspersão com 
suspensão de Xac a $10^{6}$ UFC/mL compondo os tratamentos Folha Intacta com 5, 10, $15, \ldots, 55$ e 60 dias de idade. Durante a condução do experimento, as folhas emergentes eram destacadas, evitando-se possíveis equívocos com as folhas marcadas.

No experimento B, para analisar o efeito da idade do ferimento mecânico, folhas novas de limão foram perfuradas com agulha histológica em seis pontos eqüidistantes. As folhas com 0, 1, .., 7 e 8 dias após o ato de ferimento foram inoculadas por aspersão do inóculo a $10^{6} \mathrm{UFC} / \mathrm{mL}$, compondo os tratamentos Folha c/ Ferimento de 0 a 8 dias de idade. $O$ experimento $B$ teve duas repetições no tempo: experimento 1 (Exp. 1) e experimento 2 (Exp. 2), com 9 tratamentos.

No experimento $C$, para avaliar a influência da idade da injúria de $L M C$, mudas de Limão Tahiti com brotações novas foram oferecidas à postura de $P$. citrella em gaiolas entomológicas (Chagas \& Parra, 2000). Plantas com folhas infestadas com ovos de $P$. citrella foram inoculadas por aspersão após $0,2,4, \ldots, 34$ e 36 dias da ovoposição na concentração mencionada anteriormente, compondo os tratamentos Folha $c /$ LMC de 0,2 até 36 dias de idade. $O$ experimento $C$ teve duas repetições no tempo: Exp. 1 e Exp. 2, com 37 tratamentos.

A inoculação por aspersão foi obtida com o emprego de bomba a vácuo com pulverizador, inoculando os dois lados do limbo foliar. Depois de inoculadas, as plantas foram mantidas em condições de câmara úmida por 96 horas com temperatura controlada a $28^{\circ} \mathrm{C} \pm 2$ e fotofase de 12 horas. As condições de câmara úmida foram obtidas através de gaiolas entomológicas de acrílico vedadas, contendo no seu interior bandejas com água e as paredes umedecidas com borrifador. Após as 96 horas, as plantas foram transferidas para prateleiras na sala, sob as mesmas condições de temperatura. 
Em cada tratamento, no final de 30 dias após a inoculação, coletou-se uma folha de cada planta com lesões de Cancro Cítrico, totalizando 8 folhas por tratamento. As folhas foram digitalizadas e a severidade da folha foi determinada pelo software de quantificação de doença, QUANT v.1.0 (Vale et al., 2001). Nos experimentos $B$ e $C$ somente as lesões associadas ao ferimento mecânico (Folha $\mathrm{Cl}$ Ferimento) e as injúrias de LMC (Folha $c /$ LMC) foram mensuradas e a severidade calculada em relação à área foliar.

A severidade dos tratamentos dos experimentos $A, B$, e $C$ foi analisada por regressão através do software PROC GLM do SAS (SAS, Inc., 2001) e por regressão não-linear do software STATISTICA (StatSoft, Inc.,2001) ao nível de $5 \%$ significância.

O tamanho médio de lesão foi determinado através da soma das áreas das lesões Cancro Cítrico dividido pelo número total de lesões de cada tratamento. E a densidade de lesões foi obtida dividindo-se o número de lesões pela área foliar.

\subsection{Efeito da temperatura e do período de molhamento foliar no desenvolvimento do Cancro Cítrico}

Ensaios em câmaras de crescimento permitem isolar os efeitos de fatores ambientais específicos, fornecendo dados que explicam o desenvolvimento epidêmico da doença em campo (Kranz \& Hau, 1980; Rotem, 1988). Desta forma, para determinar o efeito do ambiente sobre o desenvolvimento dos processos de infecção e colonização do Cancro Cítrico em Limão Tahiti, foi conduzido um experimento em câmaras de crescimento (Conviron, modelo E-7), com duas 
repetições no tempo, experimentos 1 e 2. Foram testadas as temperaturas de 15 , $20,25,30,35,40$ e $42^{\circ} \mathrm{C}$ e os períodos de molhamento foliar de $0,4,8,12,16,20$ e 24 horas, de maneira combinada, resultando em 56 tratamentos, distribuídos em delineamento inteiramente casualizado, com 8 repetições.

Mudas de Limão Tahiti, em tubetes, apresentando brotações novas, recém emergidas, foram inoculadas por aspersão com suspensão bacteriana de Xac na concentração de $10^{6} \mathrm{UFC} / \mathrm{mL}$. Após a inoculação, grupos de 8 plantas foram envolvidos em sacos plásticos previamente umedecidos (condições de câmara úmida) e transferidos para câmaras de crescimento nas temperaturas de 15, 20, .., 40 e $42{ }^{\circ} \mathrm{C}$, com fotofase de 12 horas. $O$ efeito do período de molhamento foliar foi obtido mantendo-se os grupos de plantas nas condições de câmara úmida durante 0 , $4, \ldots, 20$ e 24 horas. $O$ período de zero hora de molhamento foliar correspondeu à ausência da câmara úmida após a inoculação. Nos tratamentos a 40 e $42^{\circ} \mathrm{C}$, as câmaras de crescimento foram reguladas, 48 horas após a inoculação, para a temperatura de $35^{\circ} \mathrm{C}$ durante o período noturno com o objetivo de evitar a ação do calor excessivo sobre as plantas.

O número de mudas doentes foi avaliado a cada dois dias. Trinta dias após a inoculação, nos tratamentos apresentando $100 \%$ de incidência, uma folha de cada planta apresentando lesões de Cancro foram destacadas e digitalizadas. A severidade foi mensurada através do software QUANT v. 1.0. (Vale et al., 2001).

Com os dados de incidência foram construídas curvas de progresso da doença e calculadas as áreas abaixo da curva de progresso da doença para os diversos tratamentos.

A área abaixo da curva de progresso da doença (AUDPC) e a área abaixo da curva de progresso da incidência do Cancro Cítrico estandardizada (AUDPC*) para cada tratamento foi calculada por integração trapezoidal, descritas no item 3.6. 
Em cada um dos tratamentos em relação ao período de molhamento ( 0 a 24 horas), a densidade média de lesão foi obtida dividindo-se o número de lesões de Cancro Cítrico pela área foliar e o tamanho médio de lesão através da soma das áreas das lesões dividido pelo número total de lesões. Os dados obtidos foram interpretados por regressão não-linear.

Com auxílio do aplicativo STATISTICA (StatSoft, Inc., 2001), a severidade dos tratamentos foi ajustada por regressão não-linear testando-se alguns modelos epidemiológicos (monomolecular, logístico, Gompertz e Beta). As equações obtidas das regressões não-lineares foram analisadas pelos coeficientes de determinação $\left(R^{2}\right)$.

$O$ efeito do período de molhamento foliar na severidade da doença foi explicado pelo modelo monomolecular $Y=1-\left(1-b_{1}{ }^{\star} \exp \left(-b_{2}{ }^{\star} M\right)\right)$, onde $Y$ representa $a$ severidade da doença, $b_{1}$ e $b_{2}$ estão relacionados, respectivamente, ao parâmetro do modelo e à taxa de infecção e $M$ representa a duração do período de molhamento (Bergamin Filho \& Amorin, 1996). O ajuste da duração do período de molhamento na severidade de doenças normalmente é descrita por modelos nãolineares que assumem as premissas básicas de que a severidade aumenta com a duração do período de molhamento e tende a um limite superior quando o período de molhamento é prolongado (Godoy et al., 1999). Para obter a estabilização assintótica da curva, a proporção de doença observada foi transformada dividindose cada valor de severidade pela severidade máxima observada $\left(S_{\max }\right)$. Assim, a máxima severidade transformada foi igual a 1. Os valores previstos pela regressão não-linear foram multiplicados por $S_{\max }$ para a representação gráfica dos dados. $A$ integração de $S_{\max }$ com a equação monomolecular leva a: $Y=S_{\max }{ }^{\star}\left(1-\left(1-b_{1}{ }^{*} \exp (-\right.\right.$ $\left.b_{2}{ }^{\star} M\right)$ ). 
Para descrever a influência da temperatura no desenvolvimento do Cancro Cítrico, a severidade foi ajustada à função Beta generalizada: $Y=b_{1}^{\star}(((T$ $\left.\left.\left.b_{2}\right)^{b 3}\right)^{\star}\left(\left(b_{4}-T\right)^{b 5}\right)\right)$, onde $b_{2}$ e $b_{4}$ representam, respectivamente, as temperaturas mínima e máxima para o desenvolvimento da doença, $b_{1}, b_{3}$ e $b_{5}$ são parâmetros da equação, desprovidos de significado biológico, T é a temperatura e $Y$, a severidade (Hau \& Kranz, 1990).

As funções monomolecular e beta generalizada, obtidas no experimento, foram multiplicadas para a elaboração de um modelo que indicasse o efeito de diferentes combinações de temperatura e períodos de molhamento foliar no desenvolvimento do Cancro Cítrico, gerando uma superfície de resposta de severidade em função dessas variáveis climáticas. A integração das duas equações gera a função Beta-monomolecular: $Y=b_{1}{ }^{*}\left(\left(\left(T-b_{2}\right)^{b 3}\right)^{\star}\left(\left(b_{4}-T\right)^{b 5}\right)\right)^{\star}(1-(1-$ $\left.\left.b_{7}{ }^{\star} \exp \left(-b_{8}{ }^{\star} M\right)\right)\right)$. 


\section{RESULTADOS E DISCUSSÃO}

\subsection{Via de penetração de $X$. axonopodis pv. citri e a concentração de inóculo na severidade do Cancro Cítrico.}

Lesões de Cancro Cítrico foram observadas em todos os tratamentos, inclusive na concentração de inóculo $10^{1} \mathrm{UFC} / \mathrm{mL}$. Todas as Figuras e Tabelas dos dados avaliados se encontram no final desse tópico.

As curvas de progresso do Cancro Cítrico dos experimentos $A, B$ e $C$ estão representadas na Figura 2 e 3. Todos os tratamentos na concentração de inóculo a $10^{4}$ e $10^{6} \mathrm{UFC} / \mathrm{mL}$ apresentaram $100 \%$ de incidência, ou seja, todas as plantas apresentaram lesões de Cancro. Na concentração a $10^{2} \mathrm{UFC} / \mathrm{mL}$ o tratamento Folha Intacta teve incidência de 37,5\% (média de Exp. 1 e 2) enquanto que a incidência de Folha c/ Ferimento e Folha c/ LMC foram semelhantes, variando de 63 a 50\%, exceto para Folha c/ LMC Fase Pupa que apresentou 100\% de incidência. $O$ tratamento Fase Pupa, a $10^{1} \mathrm{UFC} / \mathrm{mL}$, foi superior aos demais, com $87 \%$ de incidência, seguido por Folha c/ LMC Fase $3^{\circ}$ instar (63\%) e Folha $\mathrm{c} /$ Ferimento (45\%, média de Exp. 1 e 2). Os outros tratamentos restantes tiveram 12 a $38 \%$ de incidência.

O período de incubação médio (PIM) do Cancro Cítrico nos 3 experimentos foi de 6 a 30 dias, dependendo do tratamento (Figura 4). $O$ menor PIM foi 
determinado para os tratamentos Folha c/ LMC Fase Pupa e Fase $3^{\circ}$ instar (6 dias), seguido para Folha c/ Ferimento Exp. 1 e Exp. 2 (8 dias), ambos na concentração de $10^{6} \mathrm{UFC} / \mathrm{mL}$, enquanto que Folha Intacta e Folha c/ LMC Fase Ovo e Fase $1^{\circ}$ ínstar variaram entre 11 e 13 dias. Os tratamentos Folha c/ LMC Fase Ovo e Fase $1^{\circ}$ ínstar, na concentração de $10^{2} \mathrm{UFC} / \mathrm{mL}$, apresentaram maior PIM, de 30 e 26 dias respectivamente. $\mathrm{Na}$ concentração de $10^{1} \mathrm{UFC} / \mathrm{mL}$, os tratamentos: Folha Intacta, Folha c/ Ferimento (exceto Exp. 1), Folha c/ LMC Fase Ovo e Fase $1^{\circ}$ ínstar, assim como os tratamentos Folha Intacta, na concentração $10^{2} \mathrm{UFC} / \mathrm{mL}$, não tiveram os seus PIM determinados, uma vez que os seus respectivos progressos de incidência de doença foram menores que 50\%. Os tratamentos Folha c/ Ferimento, com LMC Fase $3^{\circ}$ ínstar e Fase Pupa apresentaram relativa semelhança no PIM, como também Folha Intacta, Folha c/ LMC Fase Ovo e $1^{\circ}$ instar na concentração de $10^{6} \mathrm{UFC} / \mathrm{mL}$. De modo geral, à medida que se diminuiu a concentração do inóculo, houve aumento no PIM.

O efeito da concentração do inóculo na curva de progresso da doença pode ser visualizado pela AUDPC* (Figura 5). À medida que a concentração aumenta, a área abaixo da curva aumenta em razão do crescimento do número de plantas doentes (incidência) e diminuição do período de incubação, ou seja, do surgimento dos sintomas.

A ocorrência de doença mesmo em baixa concentração demonstra que poucas células bacterianas de Xac são capazes de causar infecção. Gottwald \& Graham (1992) demonstraram que lesões de Cancro podem ser provenientes da infecção de até duas células bacterianas de Xac inoculadas diretamente no interior da câmara sub-estomática.

A mínima concentração de inóculo necessária para causar infecção de Xac em mais de $50 \%$ das plantas variou de acordo com a via de penetração. A 
concentração de $10^{4} \mathrm{UFC} / \mathrm{mL}$ possibilitou infecções via estômatos e de $10^{2} \mathrm{UFC} / \mathrm{mL}$, infecções via ferimento e via injúria de LMC Fase Ovo e $1^{\circ}$ ínstar. A concentração de $10^{1}$ UFC/mL foi capaz de causar infecção via injúria de LMC Fase $3^{\circ}$ ínstar e Pupa. No trabalho de Goodman (1982) e Zubrzycki \& Zubrzycki (1987), esses autores também determinaram que as concentrações de inóculo de $10^{4} \mathrm{UFC} / \mathrm{mL} e$ $10^{2} \mathrm{UFC} / \mathrm{mL}$ são, respectivamente, suficientes para causar doença em folhas intactas e feridas. Entretanto a concentração mínima testada nestes experimentos $\left(10^{1} \mathrm{UFC} / \mathrm{mL}\right)$ permitiu a infecção em $63 \%$ das plantas com LMC Fase $3^{\circ}$ ínstar e $87 \%$ das plantas com LMC Fase Pupa, pressupondo que as vias de penetração por injúria de LMC nas fases $3^{\circ}$ ínstar e Pupa são mais eficientes que as demais testadas.

$A$ variação da severidade do Cancro Cítrico dos experimentos $A, B$ e $C$, em relação às concentrações de inóculo testadas, foi analisada por regressão. As representações gráficas da severidade da doença em função das concentrações estão nas Figuras 6 a 9. Os coeficientes de determinação $\left(R^{2}\right)$ e os parâmetros das equações de regressão dos experimentos estão demonstrados nas Tabelas 1 a 4.

No experimento $A$ (Folha Intacta), as repetições Exp. 1 e 2 apresentaram equações de regressão não-linear semelhantes (Figura 6 e Tabela 1). A equação exponencial explicou melhor o progresso da doença $\left(R^{2}=0,60\right.$ e 0,65 em Exp. 1 e 2, respectivamente). A severidade cresceu exponencialmente com o aumento da concentração. A mínima e a máxima severidade estimada pela equação foram, respectivamente, de $0,05 \%$ (média de Exp. 1 e 2) na concentração de $10^{1} \mathrm{UFC} / \mathrm{mL}$ e $1,46 \%$ em $10^{6}$ UFC/mL.

No experimento $B$ (Folha $c /$ Ferimento), as repetições Exp. 1 e 2 apresentaram equações de regressão não-linear semelhantes (Figura 7 e Tabela 2). A equação exponencial apresentou bom ajuste ao progresso da doença $\left(R^{2}=0,74\right.$ e 
0,76 em Exp. 1 e 2, respectivamente). Com o aumento da concentração, a severidade cresceu exponencialmente. Na concentração de $10^{1} \mathrm{UFC} / \mathrm{mL}$, foi estimada a mínima severidade da doença de 0,19\% (média de Exp. 1 e 2) e a máxima severidade de $0,86 \%$ em $10^{6} \mathrm{UFC} / \mathrm{mL}$.

No experimento $C$ (Folha $c /$ LMC) (Figura 8 e Tabela 3), as severidades dos tratamentos Fase Ovo e Fase $1^{\circ}$ ínstar foram ajustados pela equação exponencial $\left(R^{2}=0,60\right.$ e 0,51, respectivamente), como também para a Fase $3^{\circ}$ instar e Fase Pupa $\left(R^{2}=0,87\right.$ e 0,88 , respectivamente). Na concentração de $10^{1} \mathrm{UFC} / \mathrm{mL}$, estimou-se pela equação a mínima severidade da doença de 0,11\% na Fase Ovo, 0,15\% na Fase $1^{\circ}$ ínstar, $0,65 \%$ na Fase $3^{\circ}$ ínstar e 0,57\% na Fase Pupa. A máxima severidade estimada na concentração de $10^{6} \mathrm{UFC} / \mathrm{mL}$ foi de $2,24 \%$ na Fase Ovo; $2,42 \%$ na Fase $1^{\circ}$ ínstar; $7,48 \%$ na Fase $3^{\circ}$ ínstar e $8,82 \%$ na Fase Pupa. Em relação à Folha Intacta, a severidade da Fase $3^{\circ}$ ínstar e Pupa foram, respectivamente, 5 e 6 vezes maior.

Com o objetivo de compreender melhor o papel das fases da LMC na severidade do Cancro Cítrico, foi avaliada por regressão a severidade observada em cada concentração testada em relação à injúria de LMC na Fase Ovo, $1^{\circ}$ ínstar, $3^{\circ}$ ínstar e Pupa (Figura 9 e Tabela 4). A equação de primeiro grau ajustou-se melhor ao progresso da doença para as 4 concentrações: $10^{1} \mathrm{UFC} / \mathrm{mL}\left(R^{2}=0,48\right), 10^{2}$ UFC/mL $(0,40), 10^{4}$ UFC/mL $(0,41)$ e $10^{6}$ UFC/ mL $(0,75)$. A diferença entre a severidade da Fase ovo e Fase Pupa aumentou com a elevação da concentração, como demonstrado pelos incrementos crescentes do coeficiente angular $\left(b_{1}\right)$ da equação entre $10^{1}$ e $10^{6} \mathrm{UFC} / \mathrm{mL}$. O alto valor do coeficiente angular $\left(b_{1}=1,47\right)$, na concentração de $10^{6} \mathrm{UFC} / \mathrm{mL}$, mostra uma acentuada discrepância entre a Fase Ovo e Fase Pupa na severidade da doença, indicando que há influência dos estádios de 
LMC no comportamento do Cancro Cítrico, principalmente em concentrações de inóculo mais elevadas.

A diferença das severidades entre as fases de ovo a pupa deve, provavelmente, estar associada ao tamanho das galerias de LMC que diferem em relação aos estádios de desenvolvimento da lagarta. No estádio ovo, a injúria de LMC é praticamente zero. $O$ estádio $1^{\circ}$ ínstar apresenta uma pequena mina paralela à nervura principal. Na maioria das infestações, a galeria de LMC no estádio $3^{\circ}$ ínstar ocupa cerca de 2/3 do limbo foliar, e no estádio pupa, as galerias podem cobrir todo o limbo foliar (Anexo). Durante a avaliação dos experimentos, observou-se que na Fase Ovo e $1^{\circ}$ ínstar predominaram lesões de Cancro isoladas e pequenas, enquanto que na Fase $3^{\circ}$ instar e Pupa predominaram lesões coalescentes e maiores, em muitos casos ocupando toda a galeria. Aparentemente, a severidade parece estar relacionada ao tamanho da galeria inoculada.

Para determinar a diferença entre a severidade de Folha Intacta, Folha c/ Ferimento, Folha c/ LMC Fase Ovo, Fase $1^{\circ}$ instar, Fase $3^{\circ}$ instar e Fase Pupa em cada uma das concentrações testadas, os experimentos foram comparados de dois em dois pela análise de CONTRAST do SAS (Tabela 5). Nos contrastes que diferiram, o tratamento superior foi considerado em relação ao de maior severidade média (Tabela 6). Em todas as concentrações, a severidade de Folha c/ LMC Fase $3^{\circ}$ instar e Fase Pupa foram superiores a dos outros tratamentos ( $p$ < 0,05). Na concentração de $10^{6} \mathrm{UFC} / \mathrm{mL}$, a severidade da Fase Pupa diferiu da Fase $3^{\circ}$ instar em $p<0,06$. Em Folha $c /$ LMC Fase Ovo e Fase $1^{\circ}$ instar, a severidade foi maior $(p<0,05)$ do que em Folha $\mathrm{c} /$ Ferimento na concentração de $10^{6} \mathrm{UFC} / \mathrm{mL}$, mas não houve diferença em relação à Folha Intacta.

A semelhança $(p>0,05)$ entre a severidade Folha Intacta e Folha $c /$ Ferimento provém da metodologia adotada para quantificação da severidade. Todas 
as lesões de Cancro no limbo da Folha Intacta foram mensuradas, enquanto que na Folha c/ Ferimento, somente as lesões provenientes do ferimento mecânico foram mensuradas. A infecção de Xac ficou restrita a área do ferimento mecânico (seis pontos perfurados com agulha histológica) e na Folha Intacta a infecção bacteriana foi limitada pela área foliar. Mesmo com dimensão muito inferior, a área de ferimento da folha proporcionou lesões de Cancro com valor de severidade semelhante à área foliar intacta.

Nas folhas com LMC nas fases ovo e $1^{\circ}$ ínstar, a área injuriada (ferida) pela lagarta é extremamente pequena ou quase nula, principalmente para a fase ovo, não favorecendo a penetração de Xac via contato direto com o mesófilo foliar. A severidade de Cancro Cítrico nas Folhas c/ LMC Fase Ovo e $1^{\circ}$ ínstar provavelmente foram provenientes de infecção via estômato, o que pode explicar a similaridade com a severidade em Folhas Intactas. Em adição, a lagarta eclodida da Fase Ovo, assim como a lagarta da Fase $1^{\circ}$ ínstar, aparentemente, não contribuiu para a disseminação da bactéria no interior das galerias durante o processo de alimentação e formação das minas ou, caso houve disseminação, essa foi mínima, visto que em todas as concentrações testadas a severidade desses tratamentos não diferiram $(p>0,05)$ do tratamento com folha intacta.

Nas Folhas com LMC nos estádios de $3^{\circ}$ ínstar e pupa, em geral, o Cancro Cítrico foi superior tanto no progresso da incidência como no progresso da severidade, mesmo na menor concentração testada $\left(10^{1} \mathrm{UFC} / \mathrm{mL}\right)$. Os altos valores de severidade observados nesses tratamentos (em até 6 vezes maior que em Folha Intacta) estão diretamente correlacionados com o tamanho da área de injúria que, em muitos casos, ocupam toda a área do mesófilo foliar, permitindo a infecção de Xac via contato direto com o mesófilo foliar. 

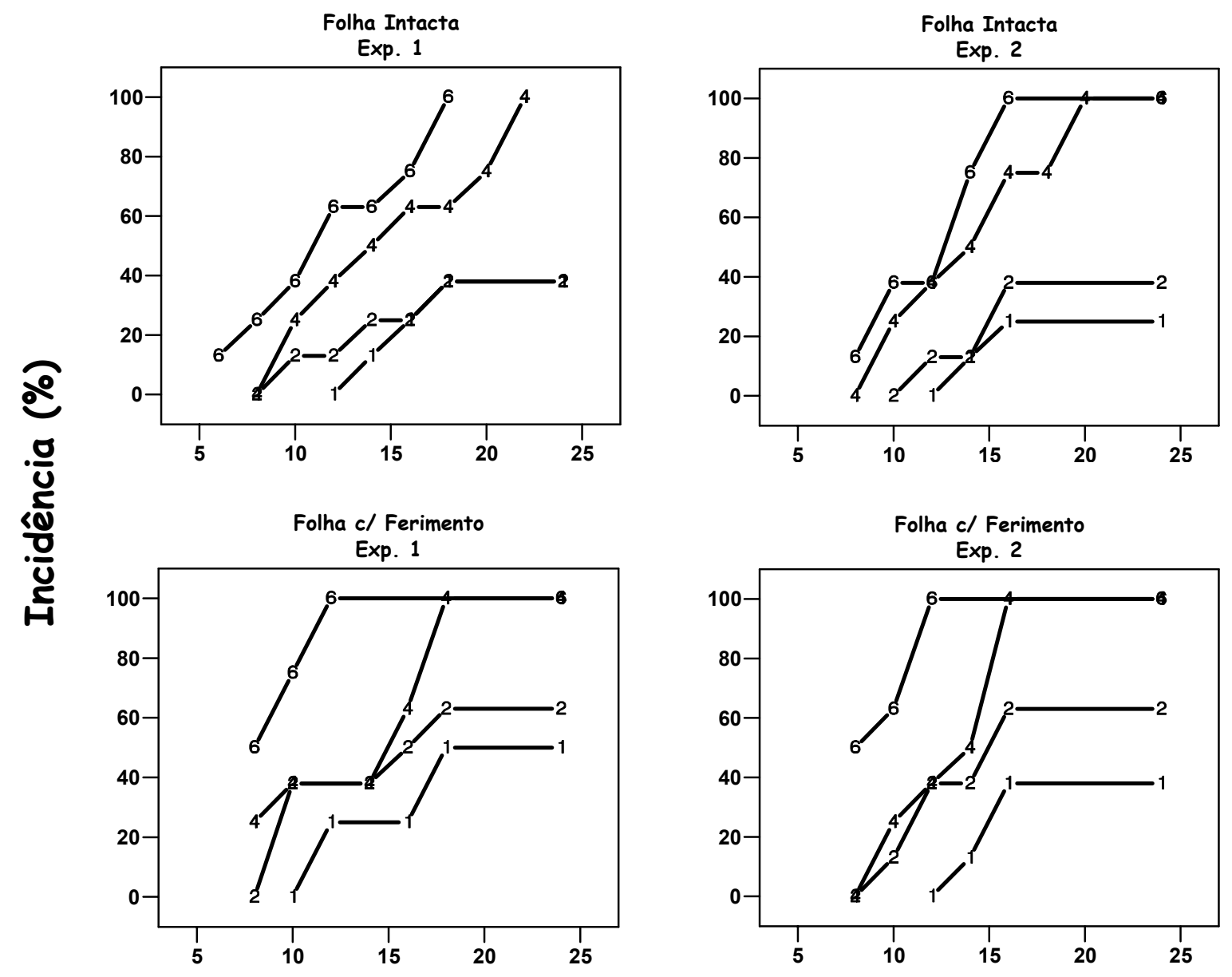

Dias após inoculação

$110^{1} \mathrm{UFC} / \mathrm{mL} ; 2-10^{2} \mathrm{UFC} / \mathrm{mL} ;-410^{4} \mathrm{UFC} / \mathrm{mL},-6-10^{6} \mathrm{UFC} / \mathrm{mL}$

Figura 2 - Curva de progresso da incidência do Cancro Cítrico em folhas de Limão Tahiti intacta e com ferimento mecânico em relação à concentração de inóculo $\left(10^{1}, 10^{2}, 10^{4}\right.$ e $\left.10^{6} \mathrm{UFC} / \mathrm{mL}\right)$ 

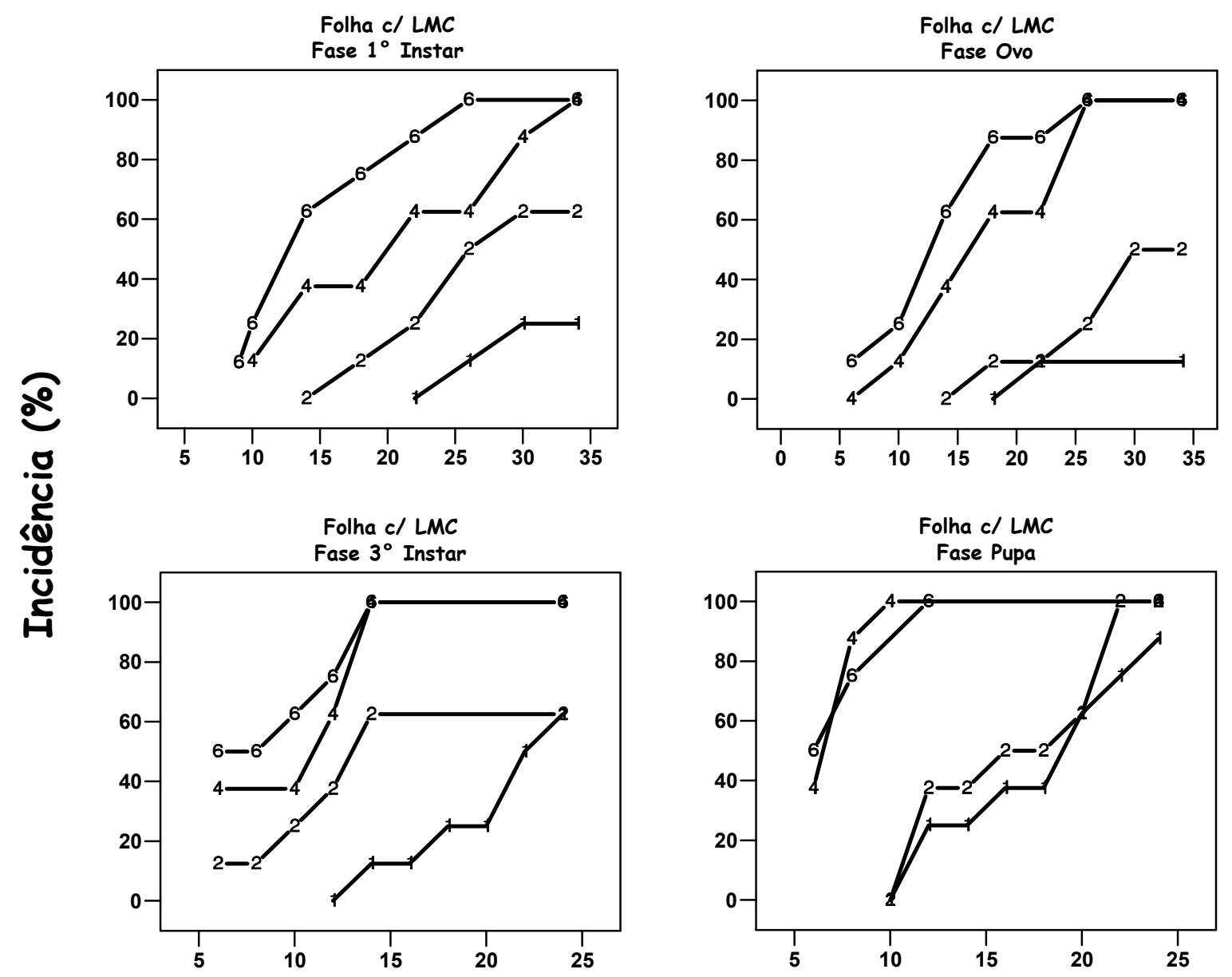

Dias após inoculação

1 $10^{1} \mathrm{UFC} / \mathrm{mL} ;$ - $210^{2} \mathrm{UFC} / \mathrm{mL} ;$ - $410^{4} \mathrm{UFC} / \mathrm{mL},-6-10^{6} \mathrm{UFC} / \mathrm{mL}$

Figura 3 - Curva de progresso da incidência do Cancro Cítrico em folhas de Limão Tahiti com injúria de LMC nas fases de ovo, $1^{\circ}$ ínstar, $3^{\circ}$ ínstar e pupa em relação à concentração de inóculo $\left(10^{1}, 10^{2}, 10^{4}\right.$ e $\left.10^{6} \mathrm{UFC} / \mathrm{mL}\right)$ 

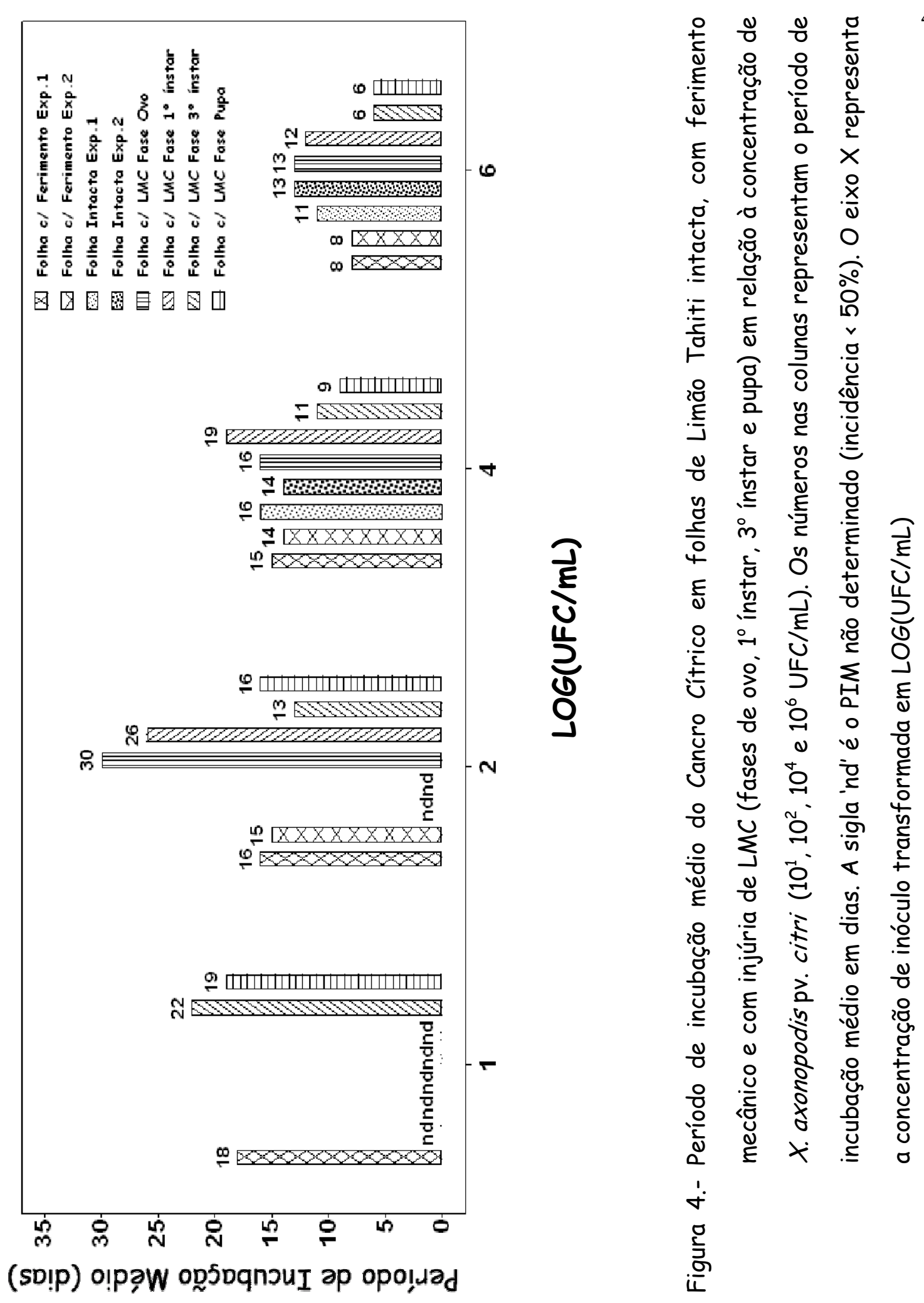

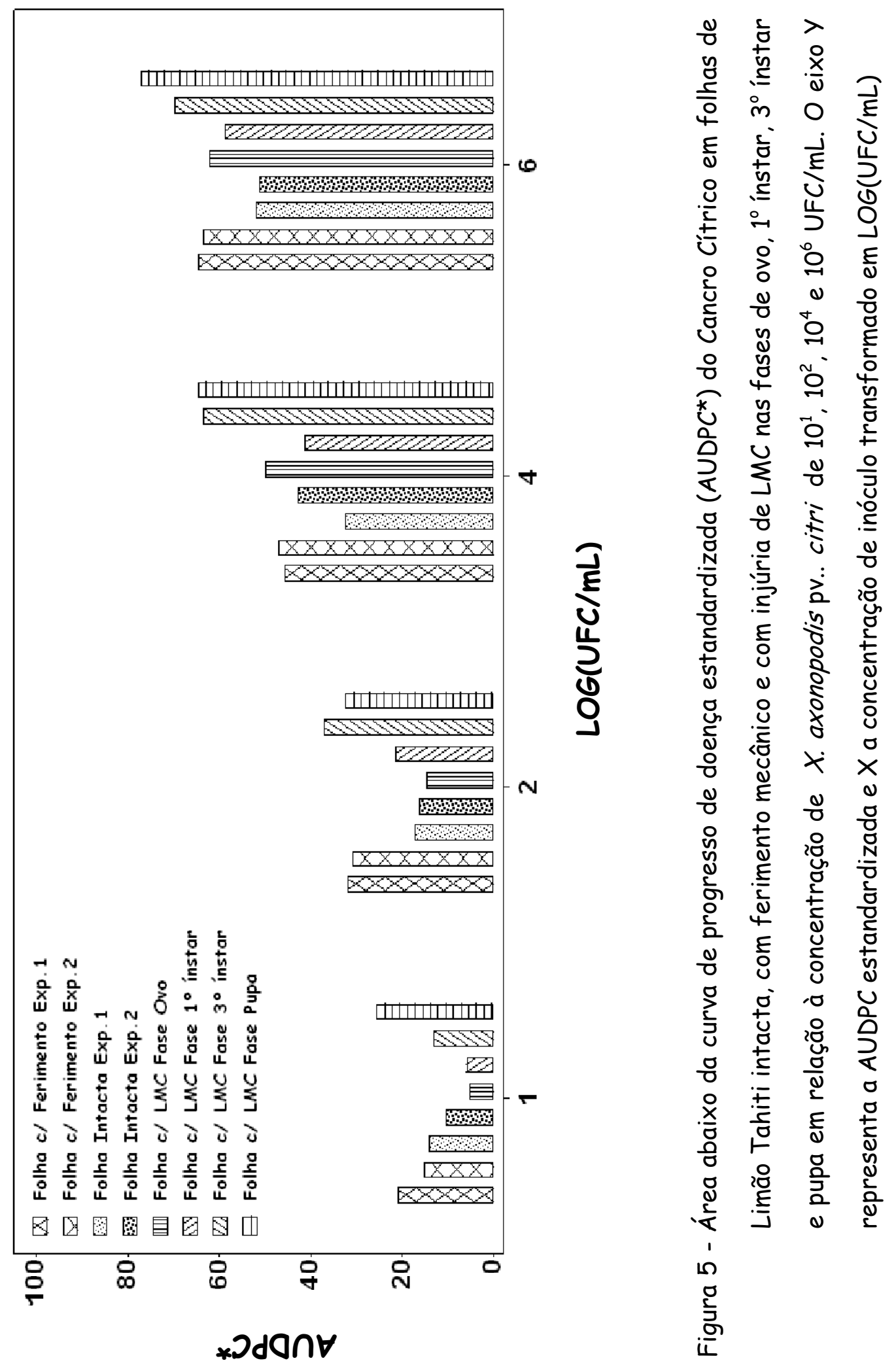

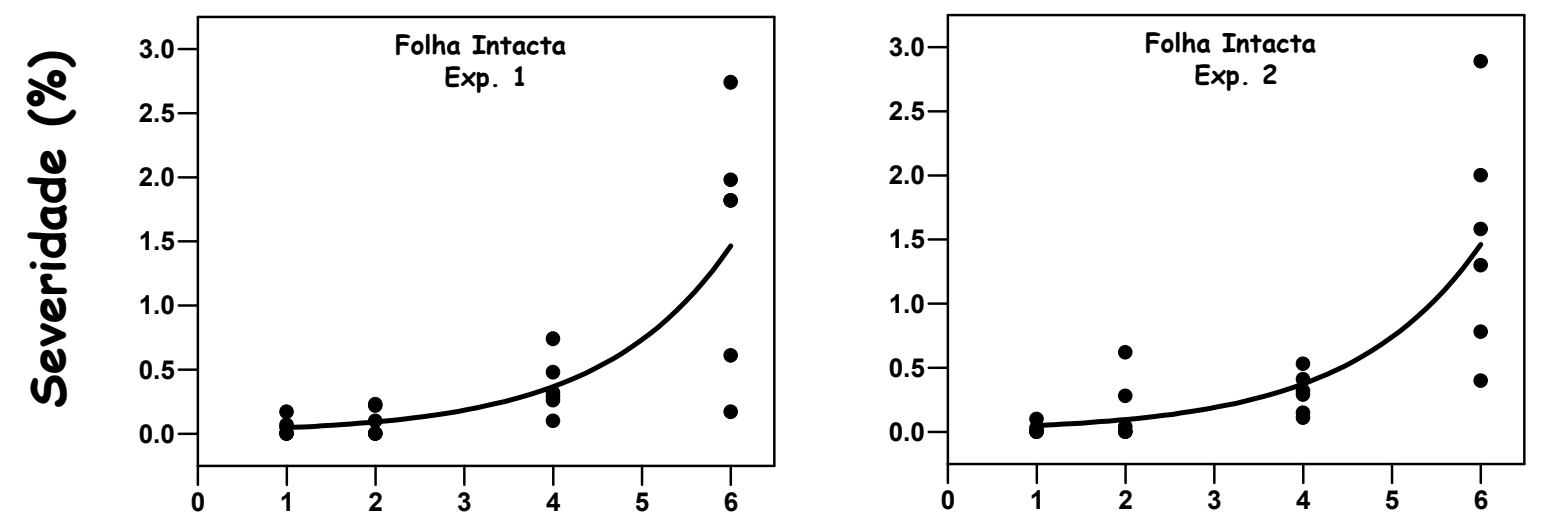

\section{LOG(UFC/mL)}

Figura 6 - Severidade do Cancro Cítrico em folhas intactas de Limão Tahiti inoculadas a $10^{1}, 10^{2}, 10^{4}$ e $10^{6} \mathrm{UFC} / \mathrm{mL}$. O eixo $X$ representa a concentração de inóculo transformado em LOG(UFC/mL)

Tabela 1. Coeficiente de determinação $\left(R^{2}\right)$ e parâmetros estimados da equação de regressão: $Y=b_{0}{ }^{\star} \exp \left(b_{1}{ }^{\star} X\right)$ para concentração de inóculo em folhas intactas dos experimentos 1 e 2, onde Y representa a severidade em porcentagem e $X$ a concentração de inóculo em LOG(UFC/mL)

\begin{tabular}{cccc}
\hline \multirow{2}{*}{ Folha Intacta } & \multicolumn{2}{c}{ Parâmetros } & $\mathbf{R}^{2}$ \\
\cline { 2 - 4 } & $\mathrm{b}_{0}$ & $\mathrm{~b}_{1}$ & \\
\hline Exp. 1 & 0,0229 & 0,6932 & 0,60 \\
Exp. 2 & 0,0243 & 0,6826 & 0,65 \\
\hline
\end{tabular}



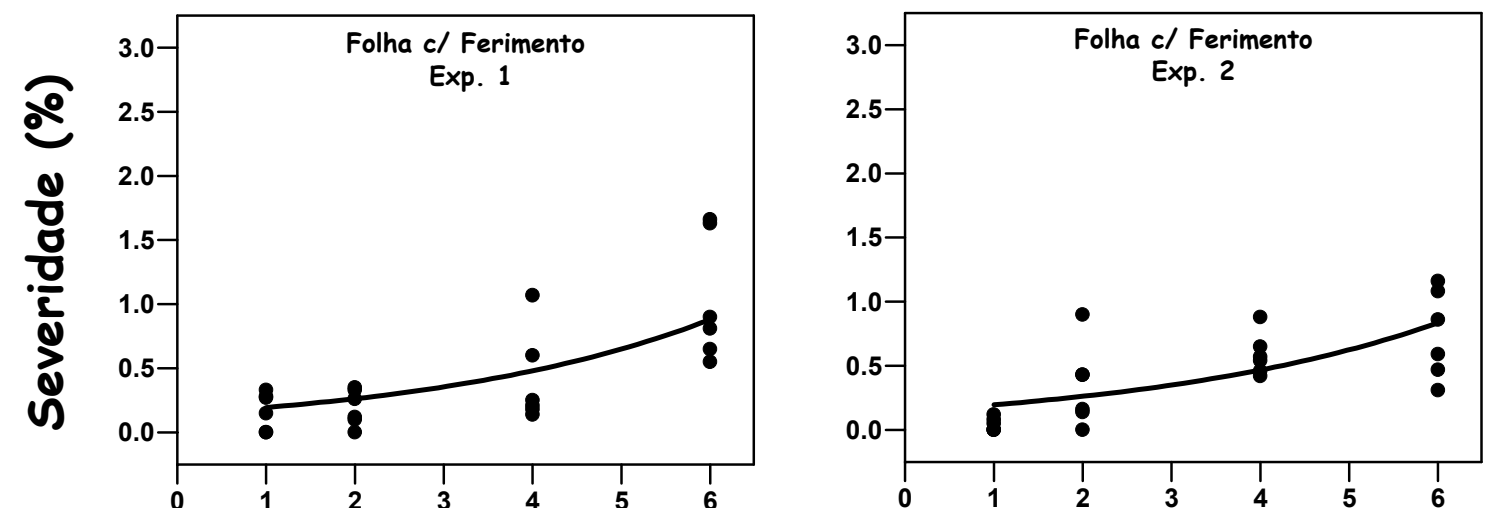

\section{LOG(UFC/mL)}

Figura 7 - Severidade do Cancro Cítrico em folhas de Limão Tahiti com ferimento mecânico inoculadas a $10^{1}, 10^{2}, 10^{4}$, e $10^{6} \mathrm{UFC} / \mathrm{mL}$. O eixo $\times$ representa a concentração de inóculo transformado em LOG(UFC/mL)

Tabela 2. Coeficiente de determinação $\left(R^{2}\right)$ e parâmetros estimados da equação de regressão: $Y=b_{0}{ }^{\star} \exp \left(b_{1}{ }^{*} X\right)$ para concentração de inóculo em folhas com ferimento mecânico dos experimentos 1 e 2, onde $y$ representa a severidade (\%) e X a concentração de inóculo em LOG(UFC/mL)

\begin{tabular}{cccc}
\hline \multirow{2}{*}{$\begin{array}{c}\text { Folha cl } \\
\text { Ferimento }\end{array}$} & \multicolumn{2}{c}{ Parâmetros } & $\mathbf{R}^{2}$ \\
\cline { 2 - 4 } & $b_{0}$ & $b_{1}$ & 0,74 \\
Exp. 1 & 0,1427 & 0,303 & 0,76 \\
Exp. 2 & 0,1454 & 0,291 & 0,0 \\
\hline
\end{tabular}



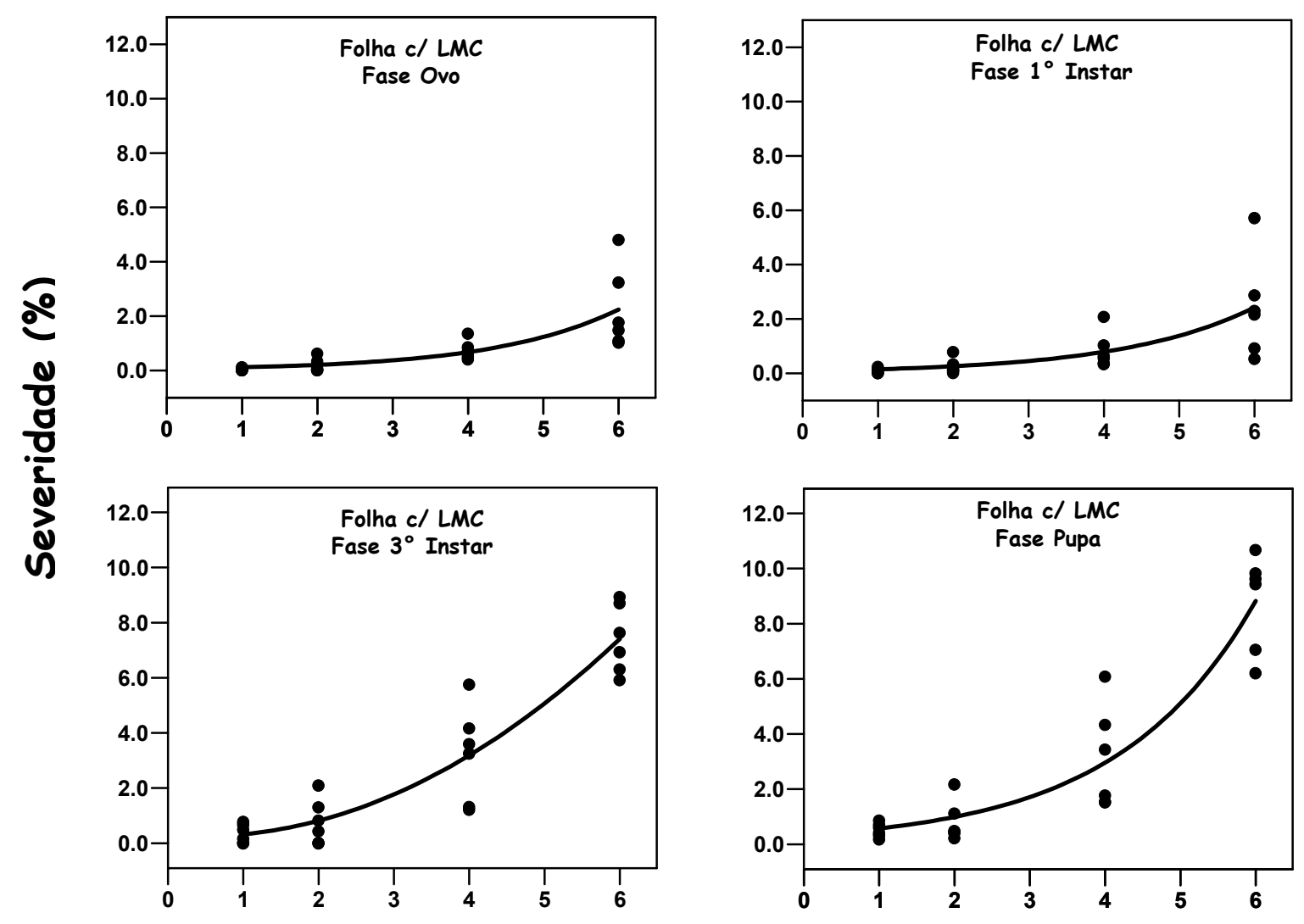

\section{LOG(UFC/mL)}

Figura 8 - Severidade do Cancro Cítrico em folhas de Limão Tahiti com injúria de LMC nas fases de ovo, $1^{\circ}$ ínstar, $3^{\circ}$ ínstar e pupa em relação à concentração de $X$. axonopodis pv. citri a $10^{1}, 10^{2}, 10^{4}$ e $10^{6} \mathrm{UFC} / \mathrm{mL}$. $O$ eixo $X$ representa a concentração do inóculo transformado em LOG(UFC/ml) 
Tabela 3. Coeficiente de determinação $\left(R^{2}\right)$ e parâmetros estimados da equação de regressão: $Y=b_{0}{ }^{\star} \exp \left(b_{1}{ }^{*} X\right)$ para os estádios de $L M C$ em relação à concentração da suspensão bacteriana, onde Y representa a severidade em porcentagem e $X$ a concentração do inóculo em LOG(UFC/mL)

\begin{tabular}{cccc}
\hline \multirow{2}{*}{ Folha c/ LMC Fase } & \multicolumn{2}{c}{ Parâmetros } & $\mathbf{R}^{2}$ \\
\cline { 2 - 3 } & $b_{0}$ & $b_{1}$ & \\
\hline Ovo & 0,0607 & 0,601 & 0,60 \\
10 Instar $^{\circ}$ Ínstar & 0,0835 & 0,561 & 0,51 \\
Pupa & 0,4001 & 0,488 & 0,87 \\
\hline
\end{tabular}



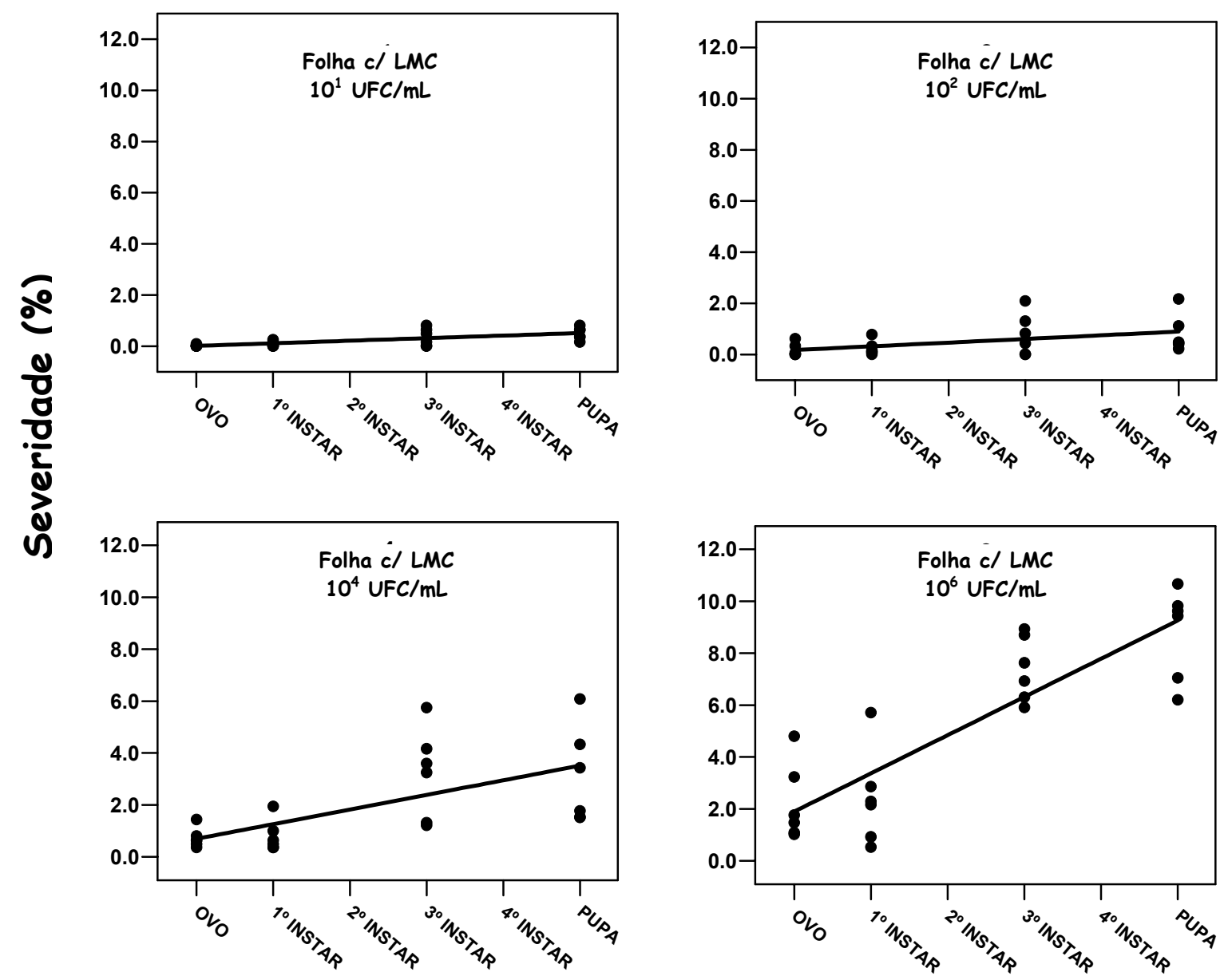

Estádios de LMC

Figura 9 - Severidade do Cancro Cítrico nas concentrações de $10^{1}, 10^{2}, 10^{4}$ e $10^{6}$ UFC/mL em relação à injúria de $L M C$ nos estádios de ovo, $1^{\circ}$ ínstar, $3^{\circ}$ ínstar e pupa em folhas de Limão Tahiti 
Tabela 4. Coeficiente de determinação $\left(R^{2}\right)$ e parâmetros estimados da equação de regressão: $Y=b_{0}+b_{1}{ }^{*} X$ para o efeito da concentração de inóculo na severidade da doença em função da injúria dos estádios de $L M C$, onde Y representa a severidade em porcentagem e $X$ o estádio de LMC

\begin{tabular}{ccccc}
\hline $\begin{array}{c}\text { Folha c/ LMC } \\
\begin{array}{c}\text { Concentração de } \\
\text { Inóculo (UFC/mL) }\end{array}\end{array}$ & \multicolumn{2}{c}{ Parâmetros } & $R^{2}$ & $P$ \\
\cline { 2 - 3 } $10^{1}$ & 0,0092 & 0,1005 & 0,48 & 0,0002 \\
$10^{2}$ & 0,1731 & 0,1436 & 0,40 & 0,0255 \\
$10^{4}$ & 0,6920 & 0,5644 & 0,41 & 0,0008 \\
$10^{6}$ & 1,8960 & 1,4730 & 0,75 & $\leq 0,001$ \\
\hline
\end{tabular}


Tabela 5. Contraste dos experimentos: Folha Intacta, Folha c/ Ferimento, Folha c/ LMC Fase Ovo, $1^{\circ}$ instar, $3^{\circ}$ ínstar e Pupa dentro de cada uma concentração

\begin{tabular}{|c|c|c|c|c|}
\hline \multirow{2}{*}{ Contraste } & \multicolumn{4}{|c|}{ Concentração de Inóculo (UFC/mL) } \\
\hline & $10^{1}$ & $10^{2}$ & $10^{4}$ & $10^{6}$ \\
\hline Intacta vs Fer & 0,2991 & 0,4269 & 0,6750 & 0,2292 \\
\hline Intacta vs Pupa & $\leq 0,0001^{\star \star}$ & $0,0036^{\star \star}$ & $\leq 0,0001^{\star \star}$ & $\leq 0,0001^{\star \star}$ \\
\hline Intacta vs $3^{\circ}$ instar & $0,0006 * \star$ & $0,0053^{\star \star}$ & $\leq 0,0001 \star \star$ & $\leq 0,0001 * \star$ \\
\hline Intacta vs $1^{\circ}$ instar & 0,5791 & 0,6014 & 0,3047 & 0,1527 \\
\hline Intacta vs Ovo & 0,8427 & 0,8478 & 0,4077 & 0,2531 \\
\hline Fer vs Pupa & $\leq 0,0001 * \star$ & $0,0192^{\star}$ & $\leq 0,0001 * \star$ & $\leq 0,0001 * \star$ \\
\hline Fer vs $3^{\circ}$ instar & $0,0061^{\star \star}$ & $0,0270^{\star}$ & $\leq 0,0001 * \star$ & $\leq 0,0001 \star \star$ \\
\hline Fer vs $1^{\circ}$ ínstar & 0,7660 & 0,8982 & 0,4911 & $0,0185^{\star}$ \\
\hline Fer vs Ovo & 0,2961 & 0,6464 & 0,6255 & $0,0371 *$ \\
\hline Pupa vs $3^{\circ}$ instar & 0,1012 & 0,9014 & 0,8542 & 0,0579 \\
\hline Pupa vs $1^{\circ}$ ínstar & $\leq 0,0001^{\star \star}$ & $0,0318^{\star}$ & $0,0002^{\star \star}$ & $\leq 0,0001$ ** \\
\hline Pupa vs Ovo & $\leq 0,0001 * \star$ & $0,0161^{\star}$ & $\leq 0,0001 * \star$ & $\leq 0,0001 * \star$ \\
\hline $3^{\circ}$ instar vs $1^{\circ}$ instar & $0,0085^{\star \star}$ & $0,0421 *$ & $\leq 0,0001 * \star$ & $\leq 0,0001 * \star$ \\
\hline $3^{\circ}$ ínstar vs Ovo & $0,0014^{\star \star}$ & $0,0217^{\star}$ & $\leq 0,0001 \star \star \star$ & $\leq 0,0001^{\star \star}$ \\
\hline $1^{\circ}$ ínstar vs Ovo & 0,5147 & 0,7743 & 0,8613 & 0,7975 \\
\hline
\end{tabular}

* Tratamentos diferem ao nível de significância de $p<0,05$

** Tratamentos diferem ao nível de significância de $p<0,01$ 
Tabela 6. Severidade média do Cancro Cítrico dos experimentos: Folha Intacta, Folha $\mathrm{c} /$ Ferimento, Folha $\mathrm{c} / \mathrm{LMC}$ Fase Ovo, Fase $1^{\circ}$ ínstar, Fase $3^{\circ}$ ínstar e Fase Pupa dentro de uma mesma concentração de inóculo

\begin{tabular}{|c|c|c|c|c|}
\hline \multirow{3}{*}{ Experimento } & \multicolumn{4}{|c|}{ Severidade Média do Cancro Cítrico (\%) } \\
\hline & \multicolumn{4}{|c|}{ Concentração de Inóculo (UFC/mL) } \\
\hline & $10^{1}$ & $10^{2}$ & $10^{4}$ & $10^{6}$ \\
\hline Folha Intacta & 0,04 & 0,12 & 0,33 & 1,51 \\
\hline Folha c/ Ferimento & 0,11 & 0,27 & 0,50 & 0,89 \\
\hline $\begin{array}{l}\text { Folha c/ LMC } \\
\text { Fase Ovo }\end{array}$ & 0,02 & 0,17 & 0,73 & 2,23 \\
\hline $\begin{array}{l}\text { Folha } \mathrm{c} / \mathrm{LMC} \\
\text { Fase } 1^{\circ} \text { instar }\end{array}$ & 0,08 & 0,24 & 0,83 & 2,41 \\
\hline $\begin{array}{l}\text { Folha } c / \text { LMC } \\
\text { Fase } 3^{\circ} \text { instar }\end{array}$ & 0,35 & 0,77 & 3,21 & 7,40 \\
\hline $\begin{array}{l}\text { Folha c/ LMC } \\
\text { Fase Pupa }\end{array}$ & 0,51 & 0,81 & 3,11 & 8,80 \\
\hline
\end{tabular}




\subsection{Idade da folha intacta, do ferimento mecânico e da injúria de LMC no desenvolvimento do Cancro Cítrico}

As Figuras e Tabelas obtidas das avaliações dos dados dos experimentos se encontram no final desse tópico.

No experimento $A$, a infecção de Xac via penetração por estômatos (Folha Intacta) ocorreu em folhas com até 35 dias de idade, ou seja, 35 dias após a emissão das folhas (Figura 10). A partir dos 40 dias de idade não foram observados sintomas de Cancro Cítrico nas folhas. A equação de primeiro grau explicou melhor - progresso da doença, $R^{2}=0,57$ (Tabela 7). $A$ severidade máxima estimada pela equação foi de $2,25 \%$. No decorrer do experimento, a severidade observada foi decrescendo com o aumento da idade de folha, até a ausência da doença. Provavelmente, o decréscimo da severidade em função do aumento da idade de folha está relacionada com mecanismos que conferem resistência a Xac e são formados ou tornam-se eficazes com o tempo. Assim folhas de 5 a 15 dias de idade apresentaram maior suscetibilidade ao Cancro enquanto que folhas acima de 40 dias apresentaram resistência.

$\mathrm{Na}$ literatura, diversos autores citam a mudança do comportamento de suscetibilidade entre folhas novas e folhas maduras de citros (Lee, 1922; Stall et al., 1982; Gottwald \& Grahan, 1992; Graham et al., 1992a). As mudanças fisiológicas e morfológicas que ocorrem na folha de citros durante o seu crescimento e maturação, que interfere na infecção de Xac, ainda não estão bem esclarecidas.

A densidade e o tamanho médio de lesão de Cancro Cítrico do experimento $A$ foram analisados por regressão (Figura 11, A e B). A equação de segundo grau possibilitou melhor interpretação dos dados de densidade e a equação logarítmica para o tamanho médio de lesão (Tabela 8). A densidade de lesão aumentou até, 
aproximadamente, aos 18 dias da emissão da folha (ponto de inflexão da curva), a partir do qual a densidade diminuiu (Figura 11 A). O tamanho médio de lesão decresceu logaritimicamente com o aumento da idade da folha. O tamanho médio observado variou de 0,004 a 0,033 $\mathrm{cm}^{2}$ (Figura 11 B). Pode-se dizer que à medida que a densidade cresceu, ou seja, o número de lesões por folha aumentou, o tamanho de lesões decresceu, ocasionando diminuição dos valores da severidade. $A$ partir dos 18 dias de idade, a densidade de lesão decresceu, contribuindo para a diminuição da severidade.

No experimento $B$, a influência da idade de ferimento em relação à infecção de Xac está representada na Figura 12 (Exp. 1 e Exp. 2). O coeficiente de determinação e os parâmetros da equação de regressão dos dados analisados de Exp. 1 e 2 estão no Tabela 9.

O ferimento mecânico (agulha histológica) permitiu a infecção de Xac até aos 6 dias após o ato do ferimento (Figura 12). Segundo Goto (1990), ferimentos causados por podas, espinhos são suscetíveis a Xac por 1 a 2 dias, discordando dos resultados neste experimento. Essa discrepância com a suscetibilidade do ferimento em folha de Limão Tahiti por 6 dias pode ser, provavelmente, proveniente da cultivar estudada e das condições controladas em que se efetuou 0 presente trabalho. A diminuição da suscetibilidade dos ferimentos em relação ao tempo provém do processo de cicatrização do ferimento, impedindo o contato direto da bactéria com o mesófilo.

A análise por regressão dos experimentos repetidos no tempo (Exp. 1 e Exp. 2) apresentaram equações de regressão semelhante entre si (Tabela 9). A equação linear teve melhor ajuste ao progresso da doença $\left(R^{2}=0,49\right.$ em Exp. 1 e $R^{2}=0,56$ em Exp. 2). À medida em que a idade do ferimento aumentou, a severidade decresceu. 
A severidade máxima de doença estimada pela equação foi de 0,83\% e 0,99\% para Exp. 1 e 2, respectivamente.

A densidade de lesão, em Folha c/ Ferimento (Figura 13), foi ajustada pela equação descrita na Tabela 10. O tamanho médio de lesão não teve ajuste devido à uniformidade dos dados (Figura 14). Provavelmente a uniformidade do tamanho médio de lesão entre os tratamentos está relacionada com a área do ferimento. $O$ maior tamanho médio observado foi de $0,03 \mathrm{~cm}^{2}$ e o menor de 0,011 $\mathrm{cm}^{2}$ (Exp. 1 e 2, respectivamente, Figura 14). Comparando-se com as lesões da Folha Intacta, o tamanho máximo da lesão em Folha c/ Ferimento foram semelhantes $\left(0,03 \mathrm{~cm}^{2}\right)$ em ambos experimentos.

A semelhança entre os tamanhos de lesão de Cancro em relação à idade do ferimento provavelmente estão relacionadas com a área de ferimento. As lesões de Cancro proveniente de infecções de Xac via ferimento estão restritos à área ferida, como também, provavelmente, a sua expansão. Assim, lesões de Cancro associadas às áreas de ferimento semelhantes (metodologia empregada) também apresentaram tamanhos semelhantes. O processo de cicatrização do ferimento interferiu, aparentemente, somente na infecção de Xac, visto que as lesões originadas da área do ferimento, independente da idade, apresentaram tamanhos semelhantes. Com a diminuição da suscetibilidade do ferimento em função do tempo, houve somente decréscimo no número de lesões.

No experimento $C$, a influência da idade de injúria de $L M C$ em relação à infecção de Xac está representada na Figura 15. Lesões de Cancro Cítrico foram observadas até os 30 dias e 32 dias após a ovoposição de P. citrella nos experimentos 1 e 2, respectivamente. As injúrias de LMC permitiram a infecção de Xac na folha por um período muito superior (32 dias) quando comparado com ferimento mecânico (6 dias), indicando que ferimentos causados pela LMC demoram 
a cicatrizarem e favorecem a penetração direta da bactéria no mesófilo da folha por várias semanas. Goto (1990) observou a suscetibilidade de injúria de LMC a XaC até aos 14 dias em condição de campo.

A equação Beta generalizada, obtida por regressão não-linear, foi que melhor explicou o progresso da doença $\left(R^{2}=0,56\right.$ em Exp. 1 e $R^{2}=0,69$ em Exp. 2, Tabela 11). A severidade aumentou no decorrer do tempo até aos 18 dias de idade de injúria de LMC (ponto de inflexão), a partir da qual a severidade decresceu. A severidade máxima da doença estimada pela equação foi de $21,07 \%$ e 25,64\% para Exp. 1 e Exp. 2, respectivamente. Em relação a Folha Intacta, a máxima severidade da Folha c/ LMC foi em média 10 vezes maior.

A densidade de lesão em Folha c/ LMC (Figura 16) foi ajustada pela equação quadrática (Tabela 12). Com o avanço do tempo, a densidade diminuiu até aos 16 e 17 dias (ponto de inflexão) para Exp. 1 e 2, respectivamente, a partir dos quais apresentou crescimento. O tamanho médio de lesão (Figura 17) foi ajustado por equação de segundo grau (Tabela 13) O comportamento do tamanho médio de lesão em relação à idade de injúria de LMC foi inverso da densidade. As lesões atingiram o seu máximo tamanho aos 16 dias de idade de injúria, e desse ponto em diante diminuíram. O maior tamanho médio observado foi de $1,55 \mathrm{~cm}^{2}$ e o menor de 0,04 $\mathrm{cm}^{2}$ (Figura 17, Exp. 1 e Exp. 2) O decréscimo da densidade e o aumento do tamanho de lesão estão relacionados com a coaslência das lesões de Cancro Cítrico nas galerias de LMC. Assim, nos tratamentos com alta severidade, as lesões cobrem grande parte da área injúria da folha podendo, em alguns casos, cobrir a área toda. As lesões coalescem e formam uma ou poucas lesões de grandes extensões.

O menor tamanho médio de lesão em Folha $c / \operatorname{LMC}\left(0,04 \mathrm{~cm}^{2}\right)$ foi semelhante ao maior tamanho médio de lesão em Folha Intacta e Folha $\mathrm{c} /$ Ferimento $\left(0,03 \mathrm{~cm}^{2}\right)$. 
O máximo tamanho médio de lesão na Folha c/ LMC foi 52 vezes maior que nos outros experimentos. As lesões com grande área são frutos da coaslência de inúmeras lesões.

Segundo Gottwald \& Garnsey (1991), Gottwald \& Graham (1992), Gottwald et al. (1993) e Gottwald et al. (1997), a interação da Xac com LMC pode ser devida a duas causas: (i) a injúria causada pela LMC durante o processo de alimentação e formação das minas favorece a infecção de Xac via contato direto com o mesófilo da folha e (ii) a LMC, em contato com a célula bacteriana, dissemina a Xac no interior das galerias.

Nos experimentos Folha $c / L M C$, as injúrias de LMC favoreceram a infecção de Xac. Entretanto, o papel da lagarta na disseminação da bactéria nas galerias em formação não foi observado. Os valores mais altos de severidade e de tamanho de lesão de Cancro Cítrico foram provenientes de folhas inoculadas apresentando galerias sem lagarta ou, se presente, na fase pupa (Figura 15). O ciclo da fase larval de P. citrella é de 4 a 8 dias (Chagas \& Parra, 2000). As Folhas C/ LMC inoculadas com 0,2 e 8 dias após a ovoposição apresentaram tamanho médio de lesão e severidade menores que as folhas acima de 10 dias de idade de injúria, indicando não interferência da lagarta na disseminação dentro das galerias. Caso a LMC dissemine a Xac no interior da galeria (Gottwald \& Garnsey, 1991; Gottwald \& Graham, 1992; Gottwald et al., 1993 e Gottwald et al., 1997), a contribuição na severidade da doença deve ser mínima comparada à importância da injúria no aumento da severidade.

As injúrias de LMC em folhas de Limão Tahiti permitiram o desenvolvimento do Cancro Cítrico em até 32 dias após a postura da $P$. citrella, enquanto que em ferimento mecânico, a doença ocorre até aos 6 dias após o ato do ferimento. Nas folhas com injúria de $L M C$, a severidade máxima foi 10 vezes maior que em folhas 
sem ferimento. O pico máximo de doença foi aos 18 dias de idade da injúria, enquanto em folha sem e com ferimento, a suscetibilidade somente decresceu com - tempo. A injúria de LMC apresentou um forte sinergismo com a Xac, potencializando o desenvolvimento da doença. 


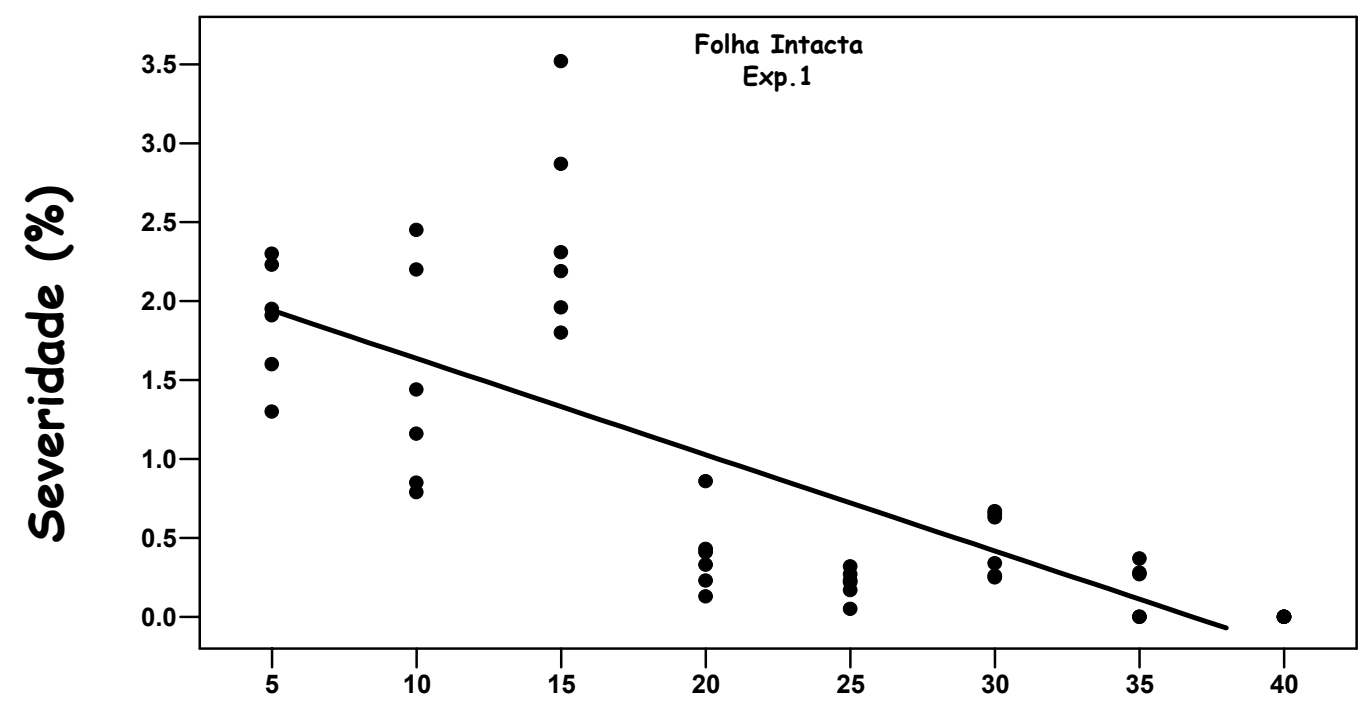

Idade de Folha (dias)

Figura 10 - Severidade do Cancro Cítrico em relação à idade de folha intacta de Limão Tahiti. As plantas com folhas de 0,5 até 60 dias de idades foram inoculadas a $10^{6} \mathrm{UFC} / \mathrm{mL}$

Tabela 7. Coeficiente de determinação $\left(R^{2}\right)$ e parâmetros estimados da equação de regressão: $Y=b_{0}+b_{1}{ }^{\star} X$ para idade de folha intacta, onde $Y$ representa $a$ severidade em porcentagem $\mathrm{X}$ a idade da folha em dias

\begin{tabular}{|c|c|c|c|c|}
\hline \multirow{2}{*}{ Idade de Folha } & \multicolumn{2}{|c|}{ Parâmetros } & \multirow{2}{*}{$R^{2}$} & \multirow{2}{*}{$P$} \\
\hline & $b_{0}$ & $b_{1}$ & & \\
\hline Exp. 1 & 2,246 & $-0,061$ & 0,57 & $\leq 0,0001$ \\
\hline
\end{tabular}



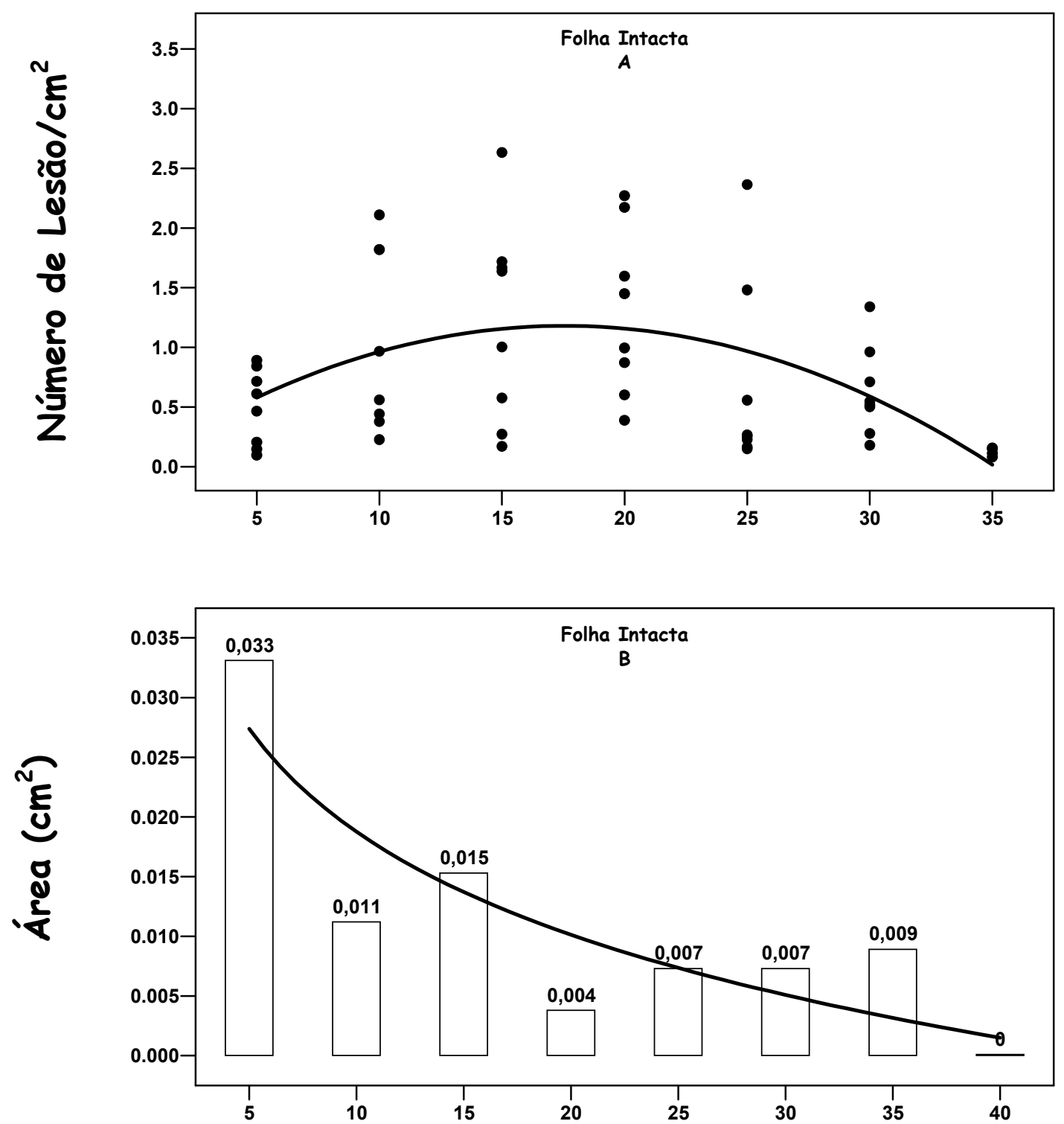

\section{Idade de Folha (dias)}

Figura 11 - Densidade (A) e tamanho médio (B) de lesão de Cancro Cítrico em relação à idade de folha de Limão Tahiti. Em $B$, as colunas representam o tamanho médio de lesão, com seus valores $\left(\mathrm{cm}^{2}\right)$ no topo e a linha a equação de regressão 
Tabela 8. Coeficiente de determinação $\left(R^{2}\right)$ e parâmetros estimados da equação de regressão: $Y=b_{0}+b_{1}{ }^{\star} X+b_{2}{ }^{\star} X^{2}$ para densidade de lesão Folha Intacta, onde $Y$ representa a número de lesões $/ \mathrm{cm}^{2}$ e $X$ a idade de folha (dias); $e$ $y=b_{0}+b_{1}{ }^{*} L O G(X)$ para tamanho médio de lesão Folha Intacta, onde $Y$ representa a área média $\left(\mathrm{cm}^{2}\right)$ e $X$ a idade de folha (dias)

\begin{tabular}{cccccc}
\hline & \multicolumn{3}{c}{ Parâmetros } & $R^{2}$ & $P$ \\
\cline { 2 - 4 } Folha Intacta & $b_{0}$ & $b_{1}$ & $b_{2}$ & & \\
\hline $\begin{array}{c}\text { Densidade de } \\
\text { lesão }\end{array}$ & 0,004 & 0,134 & $-0,0038$ & 0,22 & 0,001 \\
$\begin{array}{c}\text { Tamanho médio } \\
\text { de lesão }\end{array}$ & 0,0474 & $-0,0125$ & - & 0,76 & 0,005 \\
\hline
\end{tabular}



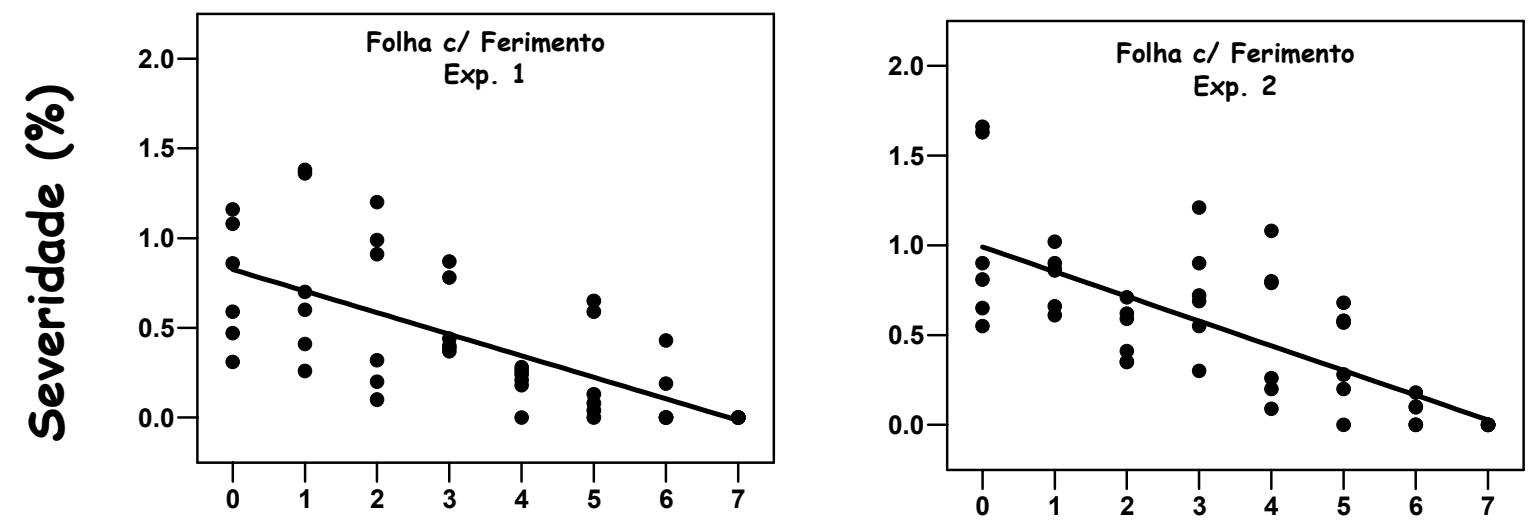

\section{Idade de Ferimento Mecânico (dias)}

Figura 12 - Severidade do Cancro Cítrico em relação à idade de ferimento mecânico em folhas de Limão Tahiti dos experimentos 1 e 2. Plantas foram inoculadas a $10^{6} \mathrm{UFC} / \mathrm{mL}$ entre 0 e 7 dias após o ferimento (agulha histológica) nas folhas jovens

Tabela 9. Coeficiente de determinação $\left(R^{2}\right)$ e parâmetros estimados da equação de regressão: $Y=b_{0}+b_{1}{ }^{*} X$ para idade de ferimento mecânico dos experimentos 1 e 2, onde Y representa a severidade (\%) e $X$ a idade de ferimento (dias)

\begin{tabular}{|c|c|c|c|c|}
\hline \multirow{2}{*}{$\begin{array}{c}\text { Idade de Ferimento } \\
\text { Mecânico }\end{array}$} & \multicolumn{2}{|c|}{ Parâmetros } & \multirow{2}{*}{$\mathbf{R}^{2}$} & \multirow{2}{*}{$P$} \\
\hline & $b_{0}$ & $b_{1}$ & & \\
\hline Exp. 1 & 0,8250 & $-0,1201$ & 0,49 & $\leq 0,0001$ \\
\hline Exp. 2 & 0,9909 & $-0,1377$ & 0,56 & $\leq 0,0001$ \\
\hline
\end{tabular}



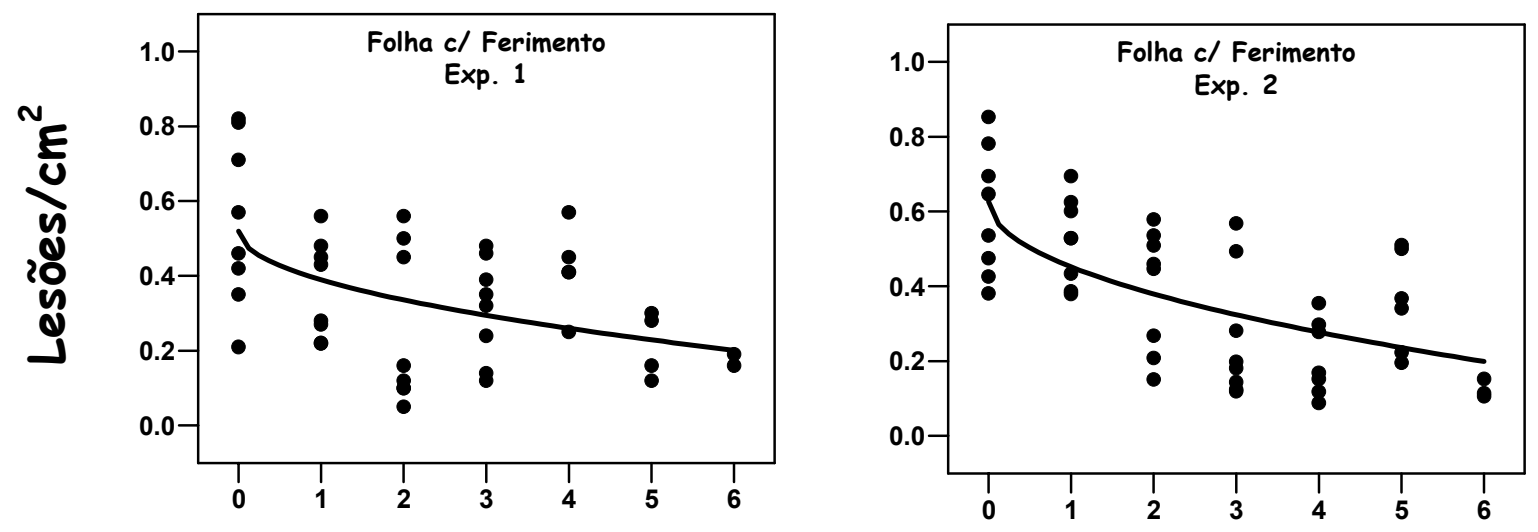

\section{Idade de Ferimento Mecânico (dias)}

Figura 13 - Densidade de lesões de Cancro Cítrico em relação à idade de ferimento mecânico em folhas de Limão Tahiti dos experimentos 1 e 2. As plantas foram inoculadas a $10^{6} \mathrm{UFC} / \mathrm{mL}$ após 0,1 até 7 dias do ferimento nas folhas jovens

Tabela 10. Coeficiente de determinação $\left(R^{2}\right)$ e parâmetros estimados da equação de regressão: $Y=b_{0}+b_{1}{ }^{\star} X^{1 / 2}$ para idade de ferimento dos experimentos $1 \mathrm{e}$ 2 , onde $Y$ representa a severidade em porcentagem $e X$ a idade de ferimento (dias)

\begin{tabular}{cccccc}
\hline \multirow{2}{*}{$\begin{array}{c}\text { Folha c/ Ferimento } \\
\text { Densidade de Lesão }\end{array}$} & \multicolumn{2}{c}{ Parâmetros } & & $\mathbf{R}^{2}$ & $\boldsymbol{P}$ \\
\cline { 2 - 3 } & $b_{0}$ & $b_{1}$ & & \\
\hline Exp. 1 & 0,5192 & $-0,1298$ & & 0,28 & 0,0003 \\
Exp. 2 & 0,6262 & $-0,1745$ & & 0,48 & $\leq 0,0001$ \\
\hline
\end{tabular}



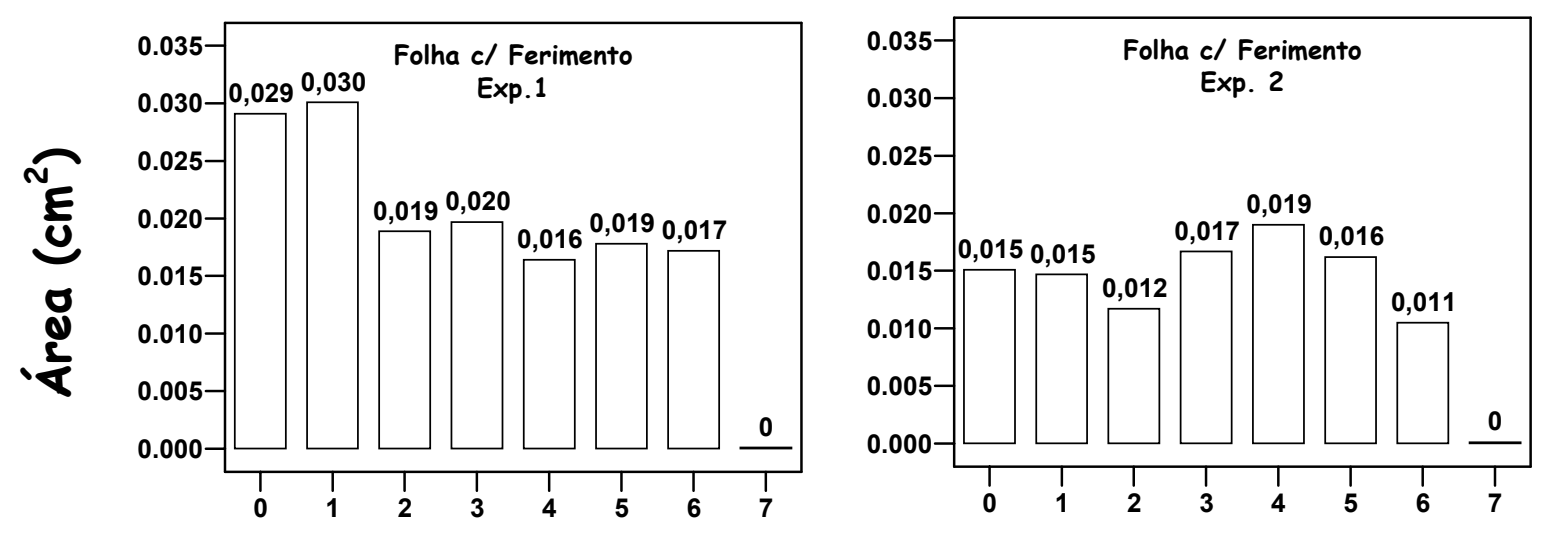

\section{Idade de Ferimento Mecânico (dias)}

Figura 14 - Tamanho médio de Lesão de Cancro Cítrico em relação à idade de ferimento mecânico em folhas de Limão Tahiti dos experimentos 1 e 2. Números nas colunas representam os valores médios do tamanho de lesão dos tratamentos 

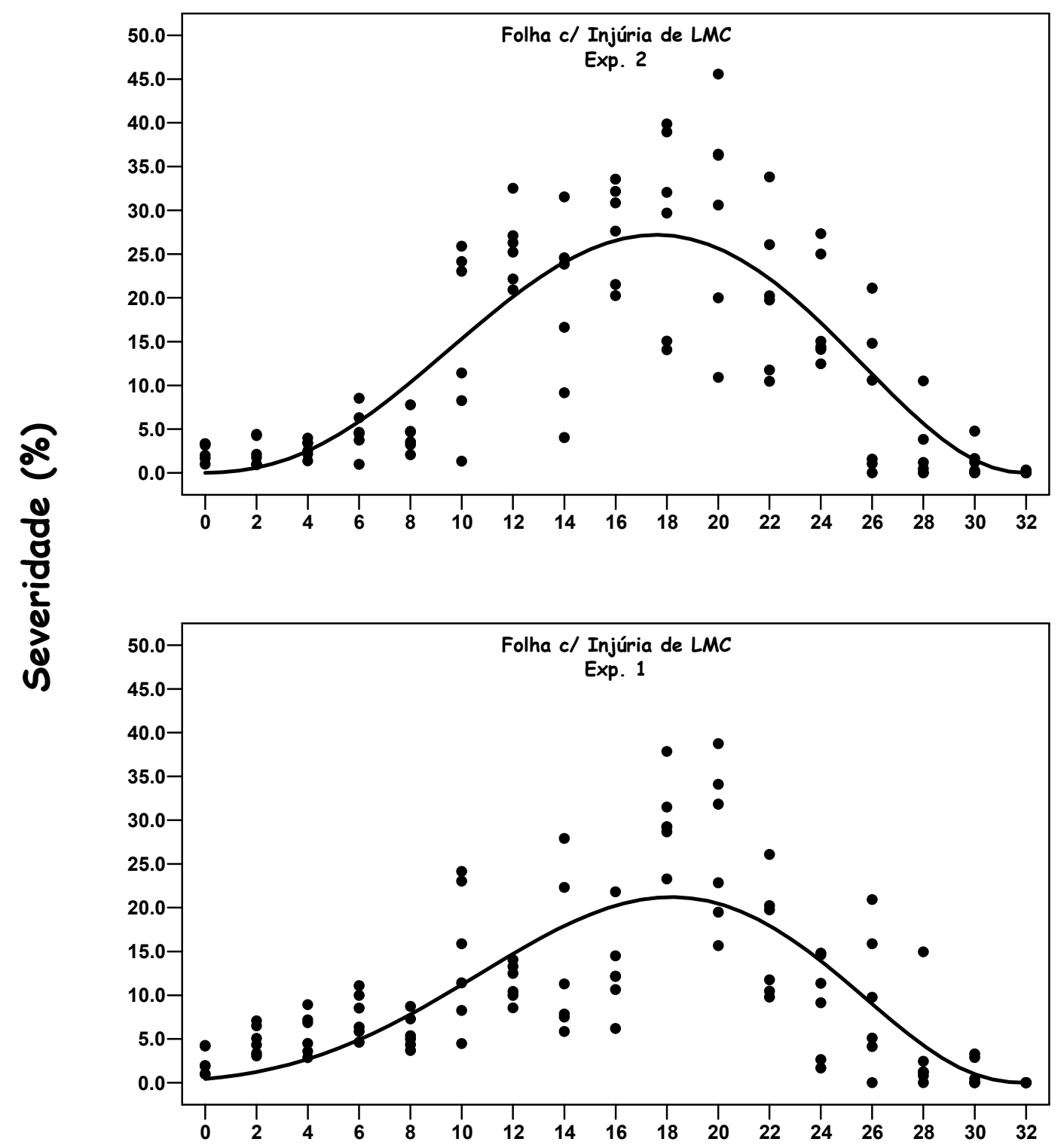

Idade de Injúria de LMC (dias)

Figura 15 - Severidade do Cancro Cítrico em relação à idade de injúria de LMC em folhas de Limão Tahiti dos experimentos 1 e 2. As plantas foram inoculadas a $10^{6} \mathrm{UFC} / \mathrm{mL}$ após 0,1 até 32 dias da ovoposição de $P$. citrella nas folhas 
Tabela 11. Coeficiente de determinação $\left(R^{2}\right)$ e parâmetros estimados pela função de Beta generalizada: $y=b_{1}{ }^{\star}\left(\left(\left(X-b_{2}\right)^{b 4}\right)^{\star}\left(\left(b_{3}-X\right){ }^{b 5}\right)\right)$ para idade de injúria de LMC dos experimentos 1 e 2, onde $Y$ representa a severidade em porcentagem, $X$ dias após o ovoposição (idade de injúria)

\begin{tabular}{|c|c|c|c|c|c|c|c|}
\hline \multirow{2}{*}{$\begin{array}{c}\text { Idade de } \\
\text { injúria }\end{array}$} & \multicolumn{5}{|c|}{ Parâmetros } & \multirow{2}{*}{$\mathbf{R}^{2}$} & \multirow{2}{*}{$P$} \\
\hline & $b_{1}$ & $b_{2}$ & $b_{3}$ & $b_{4}$ & $b_{5}$ & & \\
\hline Exp. 1 & $2,0 \times 10^{-8}$ & $-6,38$ & 32 & 4,45 & 2,50 & 0,56 & $\leq 0,0001$ \\
\hline Exp. 2 & $2,3 \times 10^{-5}$ & $-0,54$ & 32 & 2,79 & 2,21 & 0,69 & $\leq 0,0001$ \\
\hline
\end{tabular}




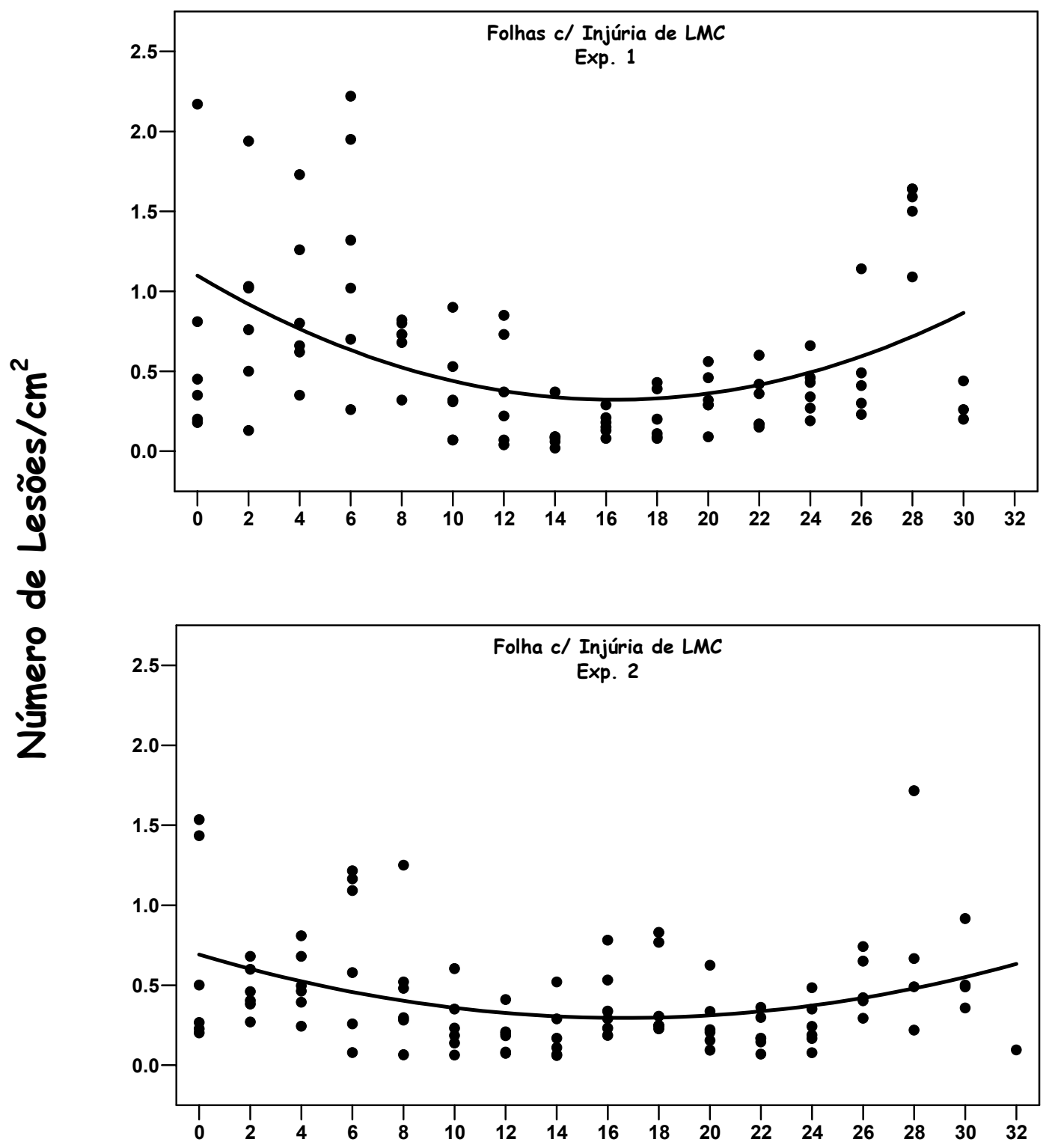

Idade de Injúria de LMC (dias)

Figura 16 - Densidade de Lesões de Cancro Cítrico em relação à idade de injúria de LMC em folhas de Limão Tahiti dos experimentos 1 e 2. Plantas foram inoculadas a $10^{6} \mathrm{UFC} / \mathrm{mL}$ entre 0 e 32 dias após ovoposição de $P$. citrella nas folhas 
Tabela 12. Coeficiente de determinação $\left(R^{2}\right)$ e parâmetros estimados da equação de regressão: $Y=b_{0}+b_{1}{ }^{*} X+b_{2}{ }^{*} X^{2}$ para densidade de lesões dos experimentos 1 e 2, onde Y representa a densidade em lesões $/ \mathrm{cm}^{2}$ e X dias decorridos após a ovoposição

\begin{tabular}{cccccc}
\hline $\begin{array}{c}\text { Folha c/ LMC } \\
\text { Densidade de } \\
\text { Lesão }\end{array}$ & $b_{0}$ & $b_{1}$ & $b_{2}$ & $R^{2}$ & $P$ \\
\cline { 2 - 5 } Exp. 1 & 1,0978 & $-0,0948$ & 0,0029 & 0,20 & $<0,0001$ \\
Exp. 2 & 0,6918 & $-0,0476$ & 0,0014 & 0,12 & 0,0016 \\
\hline
\end{tabular}




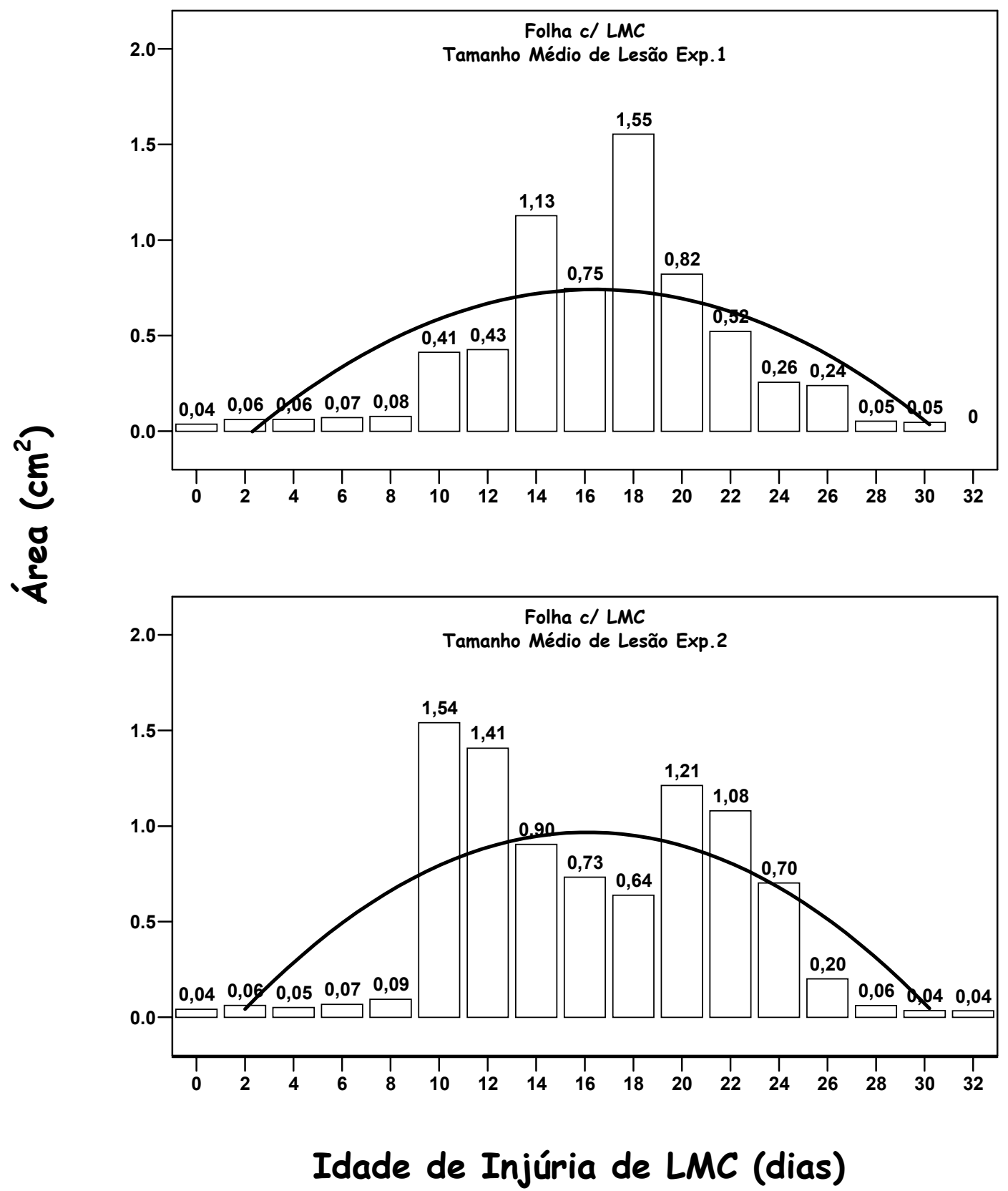

Figura 17 - Tamanho médio de lesão de Cancro Cítrico em relação à idade de injúria de LMC em folhas de Limão Tahiti dos experimentos 1 e 2. As colunas representam o tamanho médio dos tratamentos, com seus valores $\left(\mathrm{cm}^{2}\right)$ no topo e a linha a equação de regressão 
Tabela 13. Coeficiente de determinação $\left(R^{2}\right)$ e parâmetros estimados da equação de regressão: $Y=b_{0}+b_{1}{ }^{*} X+b_{2}{ }^{*} X^{2}$ para tamanho médio de lesão dos experimentos 1 e 2, onde $Y$ representa a área média $\left(\mathrm{cm}^{2}\right)$ e $X$ dias decorrido após a ovoposição

\begin{tabular}{cccccc}
\hline $\begin{array}{c}\text { Folha c/ LMC } \\
\text { Tamanho médio } \\
\text { de lesão }\end{array}$ & $b_{0}$ & $b_{1}$ & $b_{2}$ & $R^{2}$ & $P$ \\
\cline { 2 - 5 } Exp. 1 & $-0,2635$ & 0,1223 & $-0,0037$ & 0,54 & 0,0012 \\
Exp. 2 & $-0,2387$ & 0,1497 & $-0,0046$ & 0,57 & 0,0007 \\
\hline
\end{tabular}




\subsection{Efeito da temperatura e do periodo de molhamento foliar no desenvolvimento do Cancro Cítrico}

Sintomas de Cancro Cítrico foram observados em Limão Tahiti em todas as temperaturas testadas, exceto na temperatura de $42^{\circ} \mathrm{C}$ dos experimentos 1 e 2. Na temperatura de $42^{\circ} \mathrm{C}$, as folhas novas, na maioria das mudas, não suportaram 0 calor úmido excessivo nos períodos de molhamento mais longos e nas plantas remanescentes as folhas também secaram mesmo após a redução da temperatura durante o período noturno. Para os períodos de molhamento foliar, somente os tratamentos de 0 hora de molhamento não apresentaram lesões de Cancro. Todas as Figuras e Tabelas obtidas pelas análises dos dados se encontram no final desse tópico.

O período de molhamento teve pouco efeito sobre a incidência do Cancro Cítrico, como demonstrado pela AUDCP* dos experimentos 1 e 2 (Figura 18 e 19). Entretanto, o progresso da doença foi bastante influenciado pela variação da temperatura. Na Figura 20 estão representadas as curvas de progresso da doença para períodos de molhamento de 4 e 24 horas em cada temperatura. $\mathrm{Na}$ temperatura de $15^{\circ} \mathrm{C}$, as lesões de Cancro foram observadas somente a partir dos 24 dias após a inoculação, na temperatura de $20^{\circ} \mathrm{C}$, entre 14 a 17 dias, nas temperaturas de 25 a $35^{\circ} \mathrm{C}$, de 6 a 8 dias e a $40^{\circ} \mathrm{C}$, entre 11 e 12 dias. $\mathrm{O}$ surgimento das lesões entre os períodos de 4 horas e 24 horas variou em alguns dias, menos para a temperatura de $15^{\circ} \mathrm{C}$ que variou acima de 10 dias. Gottwald \& Graham (1992) relataram que sintomas de Cancro Cítrico podem aparecer depois de 60 dias sob condições abaixo das condições ótima de infecção e incubação de Xac.

O efeito da temperatura, além de interferir no período de incubação, também influenciou na taxa de incidência (Figura 20). Nas temperaturas de 20 a 
$35^{\circ} \mathrm{C}$ todos os tratamentos de molhamento foliar apresentaram $100 \%$ de incidência da doença (dados não demonstrados), exceto no tratamento com ausência de molhamento, conforme citado anteriormente. A incidência na temperatura de $15^{\circ} \mathrm{C}$ variou entre $40 \%$ e $75 \%$ em 4 e 24 horas de molhamento, respectivamente. Na temperatura de $40^{\circ} \mathrm{C}$ somente os períodos de molhamento curtos apresentaram lesões, ou seja, os períodos de 4 a 12 horas e com incidência inferior a $50 \%$, porém, no experimento 1, uma única planta apresentou a doença no período de 20 horas. A influência da temperatura no progresso da incidência pode ser observada pela $A \cup D P C^{\star}$, principalmente do experimento 2 (Figura 19) cujos valores da área abaixo da curva aumentam com a elevação da temperatura até $35^{\circ} \mathrm{C}$.

Temperaturas baixas, menores que $25^{\circ} \mathrm{C}$, interferem no aparecimento dos sintomas, aumentando o período de incubação. Entretanto, somente a temperatura de $15^{\circ} \mathrm{C}$ apresentou menos que $100 \%$ de incidência. A faixa de temperatura ótima foi de 25 a $35^{\circ} \mathrm{C}$ para os menores intervalos de aparecimento dos sintomas e a máxima incidência. A temperatura máxima para o progresso da doença foi de $40^{\circ} \mathrm{C}$. Os períodos de molhamento interferiram em alguns dias no surgimento da doença e - período de molhamento mínimo testado, de 4 horas, foi suficiente para causar $100 \%$ de doença nas temperaturas ótimas.

Com relação à densidade média de lesão, não houve correlação entre os períodos de molhamento foliar nos experimentos 1 e 2 . A temperatura foi 0 principal fator climático de interferência na variação da densidade de lesão (Figura 21 e 22). A equação Beta generalizada, obtida por regressão não-linear, ajustou-se melhor aos dados de densidade dos experimentos 1 e $2\left(R^{2}=0,73\right.$ e 0,74, respectivamente, Tabela 14). À medida em que a temperatura aumentou, a densidade cresceu até $31^{\circ} \mathrm{C}$ no Exp. 1 e $34^{\circ} \mathrm{C}$ no Exp. 2 (ponto de inflexão da curva 
obtido por derivação), a partir dos quais a densidade decresceu acentuadamente (Figura 21 e 22).

O tamanho médio de lesão também não apresentou correlação com os períodos de molhamento foliar. A regressão não-linear interpretou melhor a variação dos dados de tamanho de lesão em relação à temperatura (Figura 23 e 24). A equação Beta generalizada apresentou melhor ajuste com $R^{2}$ igual a 0,67 e 0,62 para Exp. 1 e 2 respectivamente (Tabela 14). O tamanho de lesão aumentou com a elevação da temperatura até $31^{\circ} \mathrm{C}$ e $28^{\circ} \mathrm{C}$ (ponto de inflexão da curva) nos Exp. 1 e 2, respectivamente, a partir dos quais houve decréscimo no tamanho (Figura 23 e 24).

O efeito do molhamento na severidade de Cancro Cítrico foi melhor ajustado pelo modelo monomolecular (Figura 25). A severidade aumentou com a prolongação do período de molhamento para todas temperaturas testadas, representada na Figura 25 para a temperatura de $30^{\circ} \mathrm{C}$. Os tratamentos com 24 horas de molhamento apresentaram os valores máximos de severidade enquanto que os de 4 horas apresentaram os valores mínimos. No experimento 1, não foi possível correlacionar os dados de severidade referente à temperatura de $40^{\circ} \mathrm{C}$. As equações de regressão não-linear dos períodos de molhamentos em cada temperatura testada nos experimentos 1 e 2 estão representados na Tabela 15.

May-De Mio \& Amorim (2002) e Godoy et al. (1999), em trabalho com a ferrugem do álamo e do milho, respectivamente, também obtiveram ajuste dos dados de duração do período através do modelo monomolecular.

A função Beta generalizada permitiu descrever o comportamento da doença em relação à temperatura. A severidade aumentou gradativamente com a elevação da temperatura até $30-35^{\circ} \mathrm{C}$, quando a mesma decresceu acentuadamente. $O$ comportamento da severidade em função da temperatura está ilustrado na Figura 
25 para o período de molhamento de 24 horas. As equações de regressão não-linear em função da temperatura em cada período de molhamento, com seus respectivos coeficientes de determinação encontram-se na Tabela 16.

Hau \& Kranz (1990) citam a função Beta generalizada como sendo útil para explicar o efeito da temperatura sobre o desenvolvimento de doenças de plantas. $O$ ajuste dos dados de temperatura através da função beta generalizada também foi utilizada por May-De Mio \& Amorim (2002) e Godoy et al. (1999).

A combinação dos modelos Beta generalizada e monomolecular possibilitou a construção de uma superfície de resposta de severidade de Cancro Cítrico em função temperatura e do molhamento foliar (Figura 26). As severidades mínima e máximas estimada pela equação Beta-monomolecular foram, respectivamente, de 14,9 e $42,0^{\circ} \mathrm{C}$ para Exp. 1 e 2 (Tabela 17). A máxima severidade estimada foi determinada no período de molhamento de 24 horas na temperatura de 32 e $31,4^{\circ} \mathrm{C}$ para Exp. 1 e 2, respectivamente.

O modelo Beta-monomolecular permitiu bom ajuste dos dados de proporção de doença em relação a temperatura e duração do molhamento foliar nos trabalhos de May-De Mio \& Amorim (2002) e Godoy et al. (1999).

As linhas da superfície de resposta (Figura 26) paralelas ao eixo de molhamento representam a severidade em uma determinada temperatura em relação ao período de molhamento. Entre 4 e 24 horas de molhamento, nas temperaturas de 15 e $20^{\circ} \mathrm{C}$, pode-se observar pequenas diferenças nos valores de severidade da doença, entretanto, a diferença é bastante acentuada nas temperaturas de 30 e $35^{\circ} \mathrm{C}$. Assim, à medida que a temperatura aumenta, os maiores períodos de molhamento tornam-se mais eficientes, proporcionando maiores severidades. A partir de $35^{\circ} \mathrm{C}$, a eficiência de longo período de molhamento 
diminui, e a diferença entre as severidade de 4 e 24 horas tornam-se menos acentuadas.

Nas linhas paralelas ao eixo de temperatura da superfície de resposta (Figura 26) está representada a severidade em cada molhamento em relação as temperaturas. Entre as temperaturas de 15 e $42^{\circ} \mathrm{C}$, a linha mostra incrementos crescentes até que o ponto de inflexão seja atingido $\left( \pm 32^{\circ} \mathrm{C}\right)$, seguindo-se acentuados decréscimos que tendem a zero. A curva formada é assimétrica inclinada para a direita. Com o aumento do molhamento, a curva prolonga-se no sentido da ordenada.

O sinergismo da temperatura com o período de molhamento nos componentes monocíclicos do Cancro Cítrico é bastante evidente para o progresso da severidade. O molhamento e a temperatura ótimos foram de 24 horas a $31,7^{\circ} \mathrm{C}$ (média de Exp.1 e 2) (Figura 26). O aumento da severidade pode ser associado com aumento da densidade de lesão, que apresentou o máximo valor na temperatura de $32,5^{\circ} \mathrm{C}$ (Figura 21 e 22) combinado com a máxima área média de lesão obtida na temperatura de $29^{\circ} \mathrm{C}$ (Figura 22 e 23). 

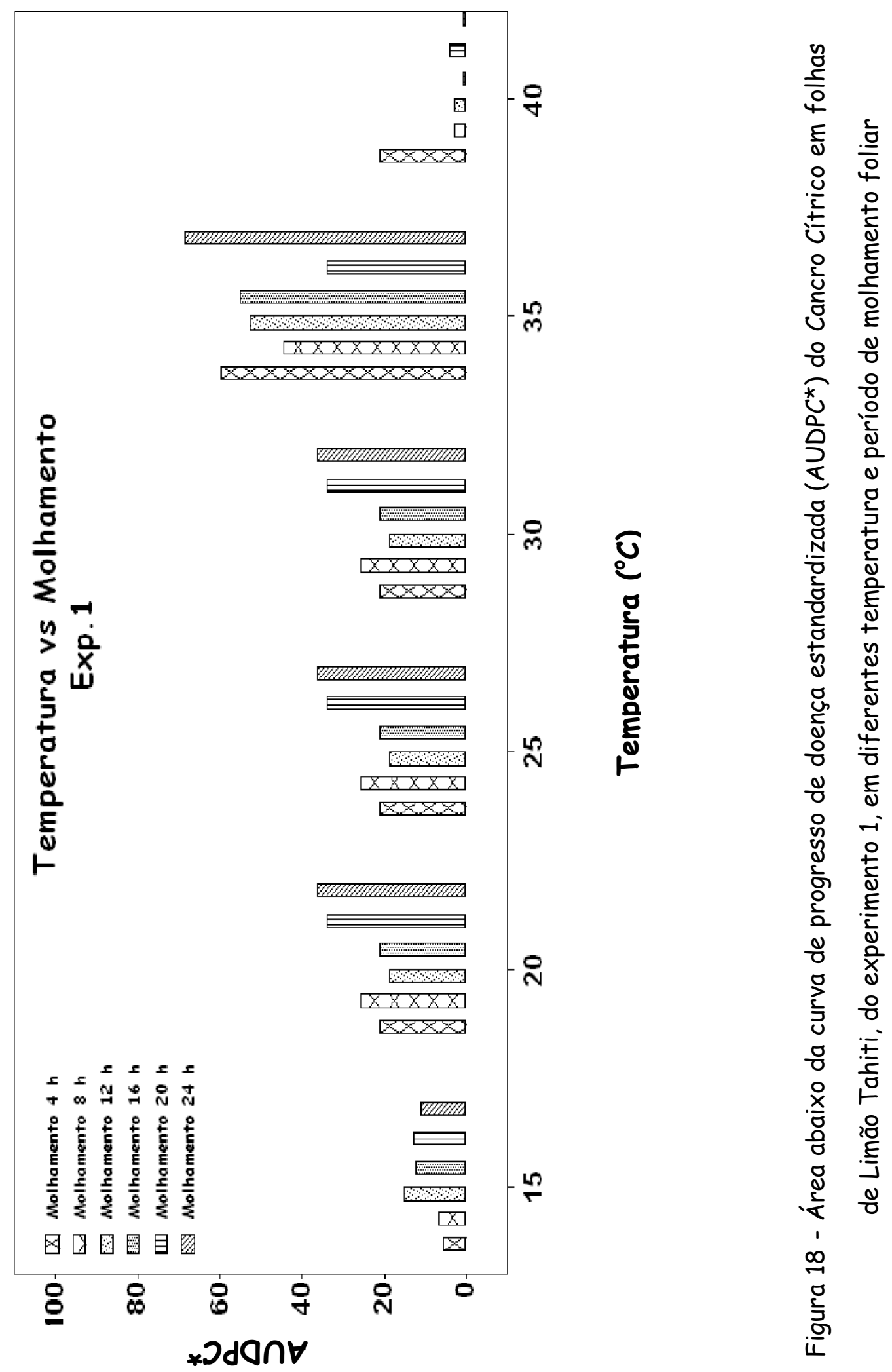

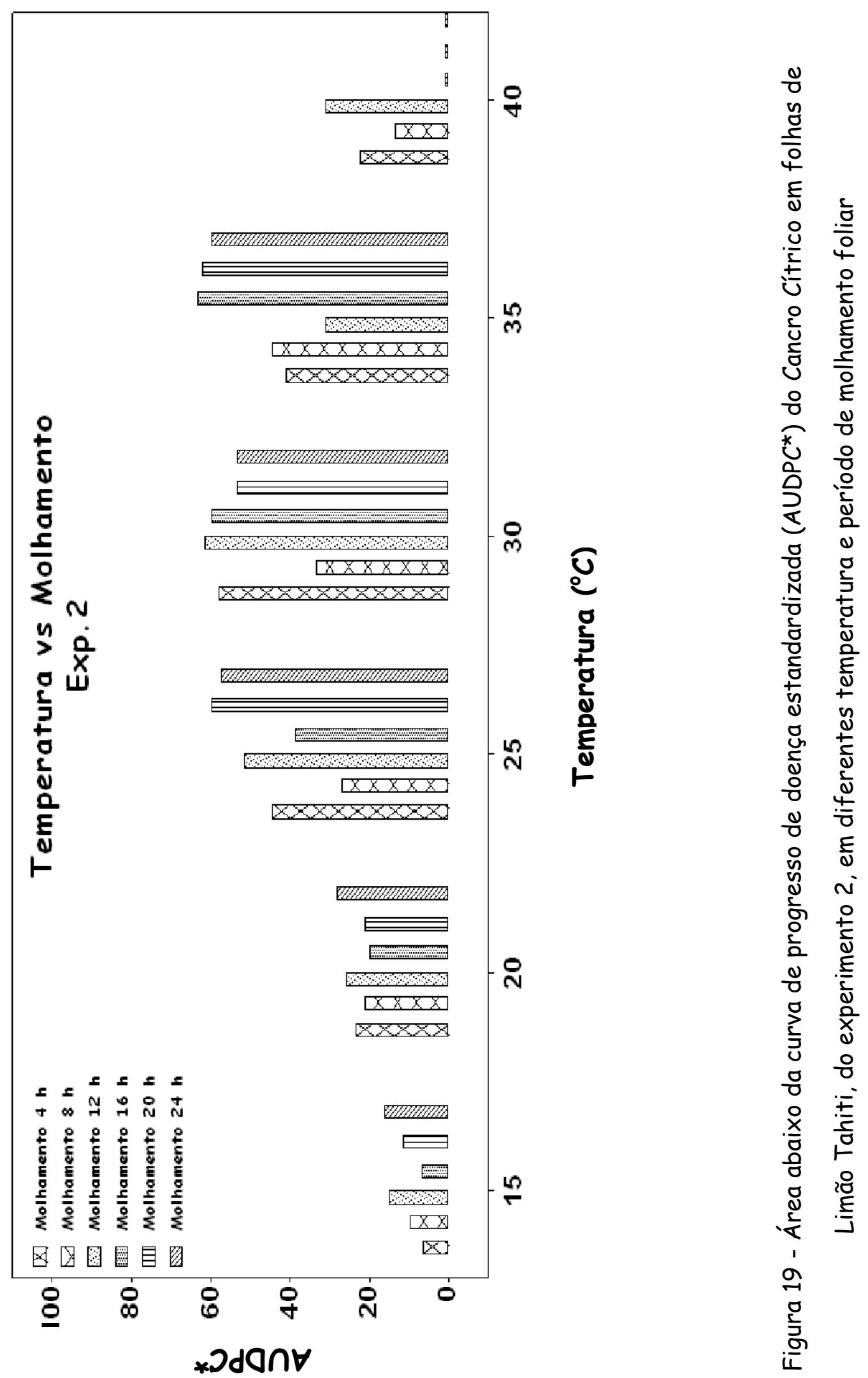

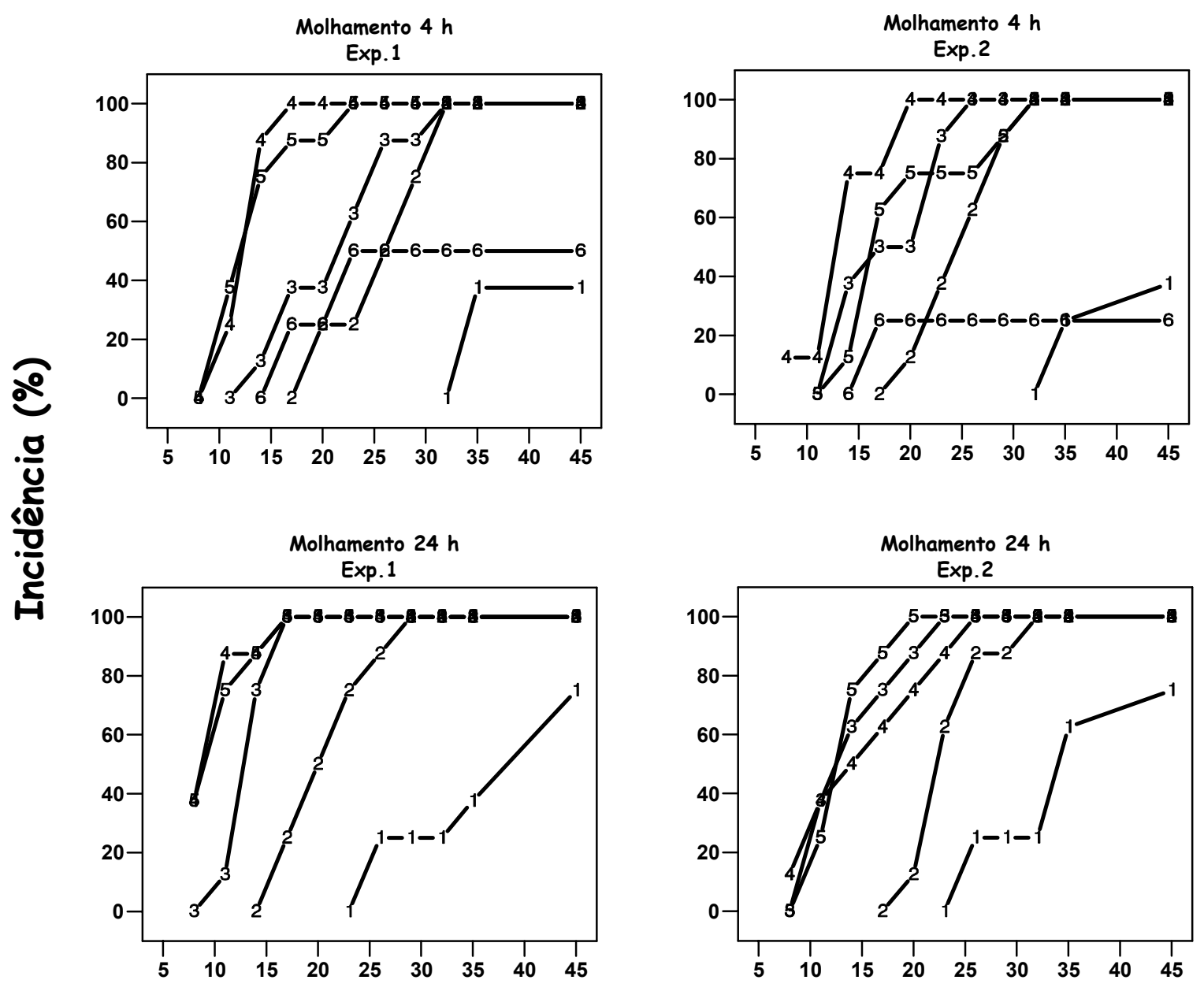

Dias após inoculação

$115^{\circ} \mathrm{C} ; 220^{\circ} \mathrm{C} ;-3-25^{\circ} \mathrm{C} ;-30^{\circ} \mathrm{C} ;-5-35^{\circ} \mathrm{C} ;-6-40^{\circ} \mathrm{C}$

Figura 20 - Curva de progresso da incidência do Cancro Cítrico em folhas de Limão Tahiti em condições de período de molhamento de 4 e 24 horas em relação às temperaturas de $15,20,25,30,35$ e $40^{\circ} \mathrm{C}$. 

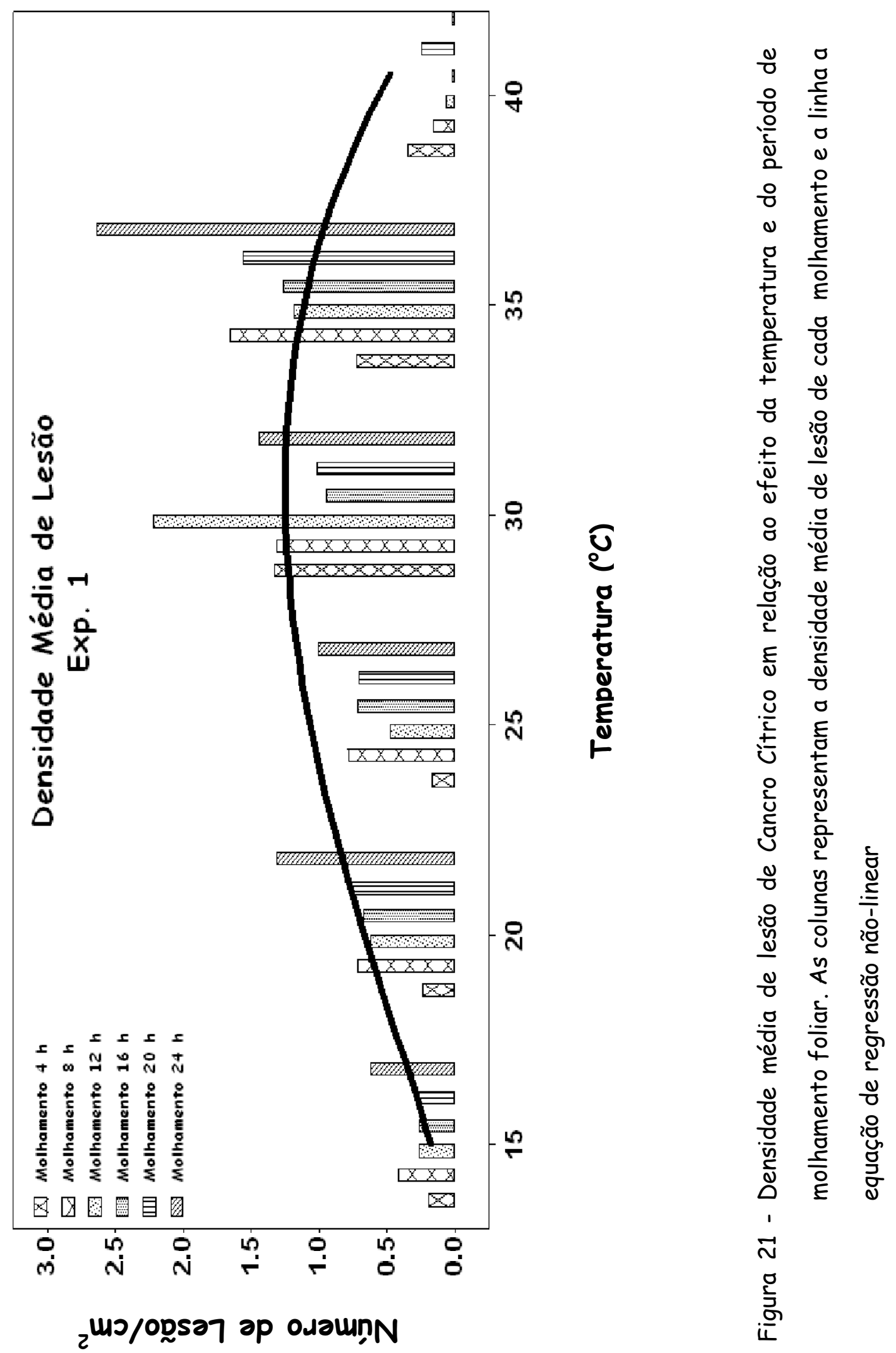

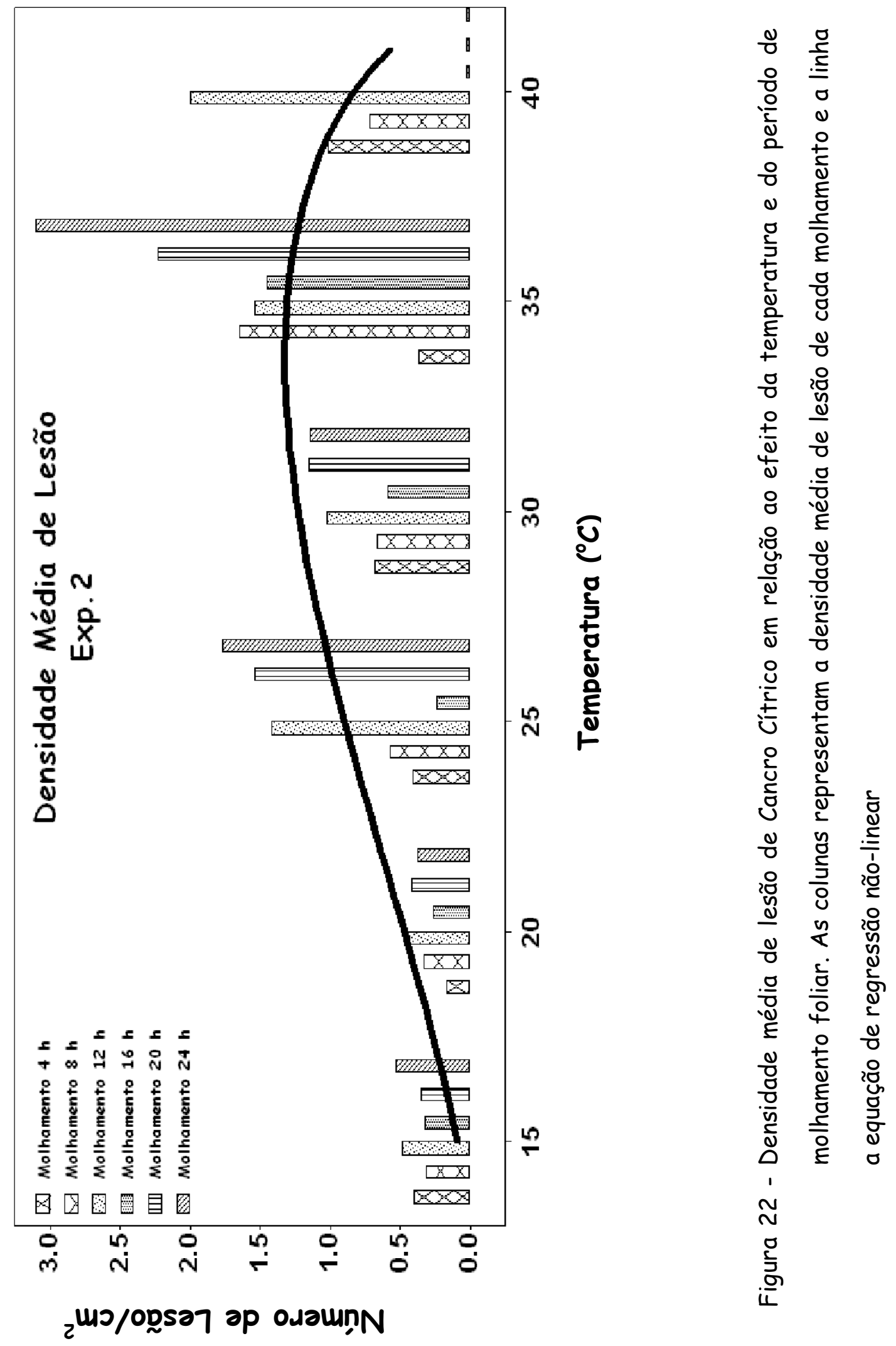

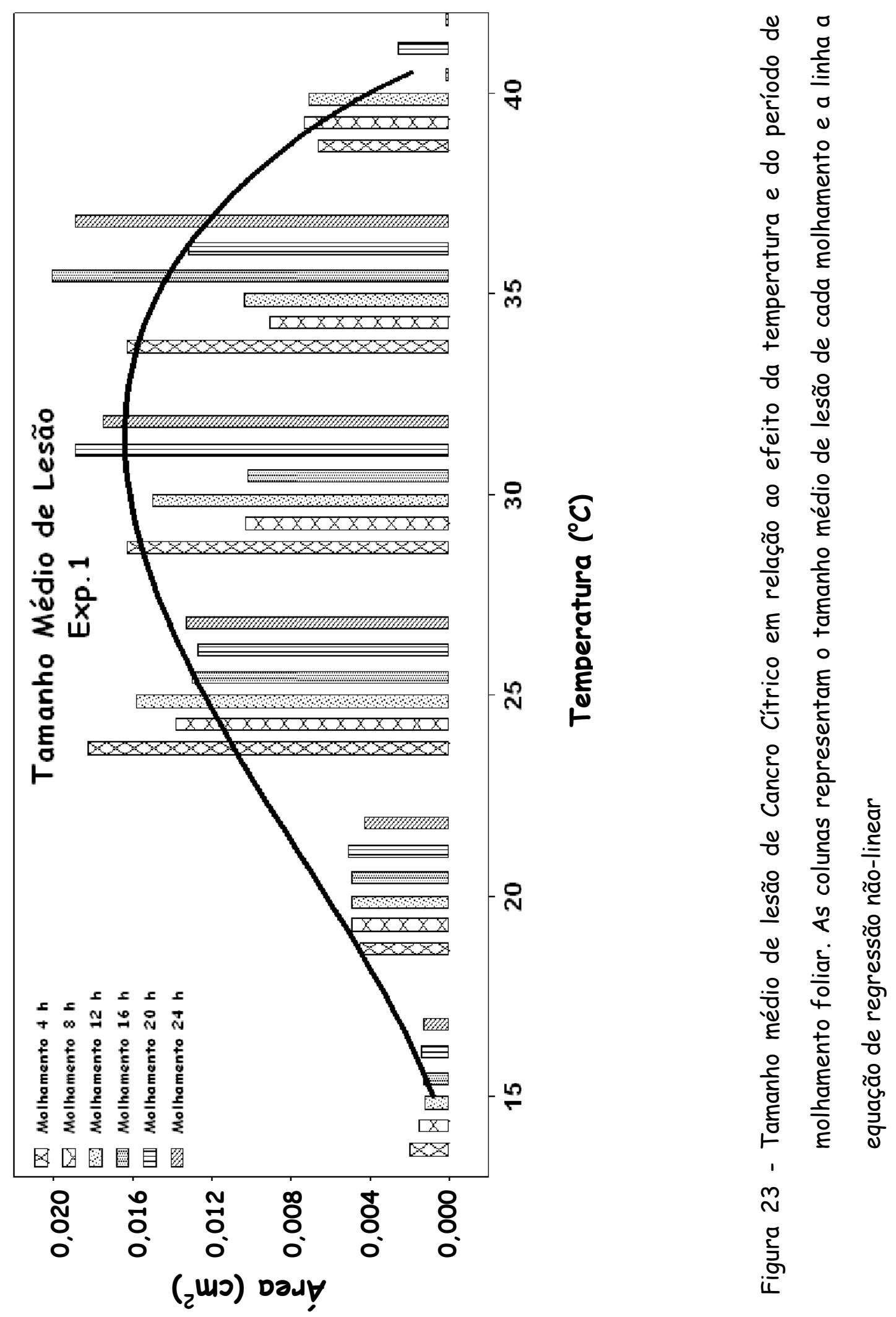

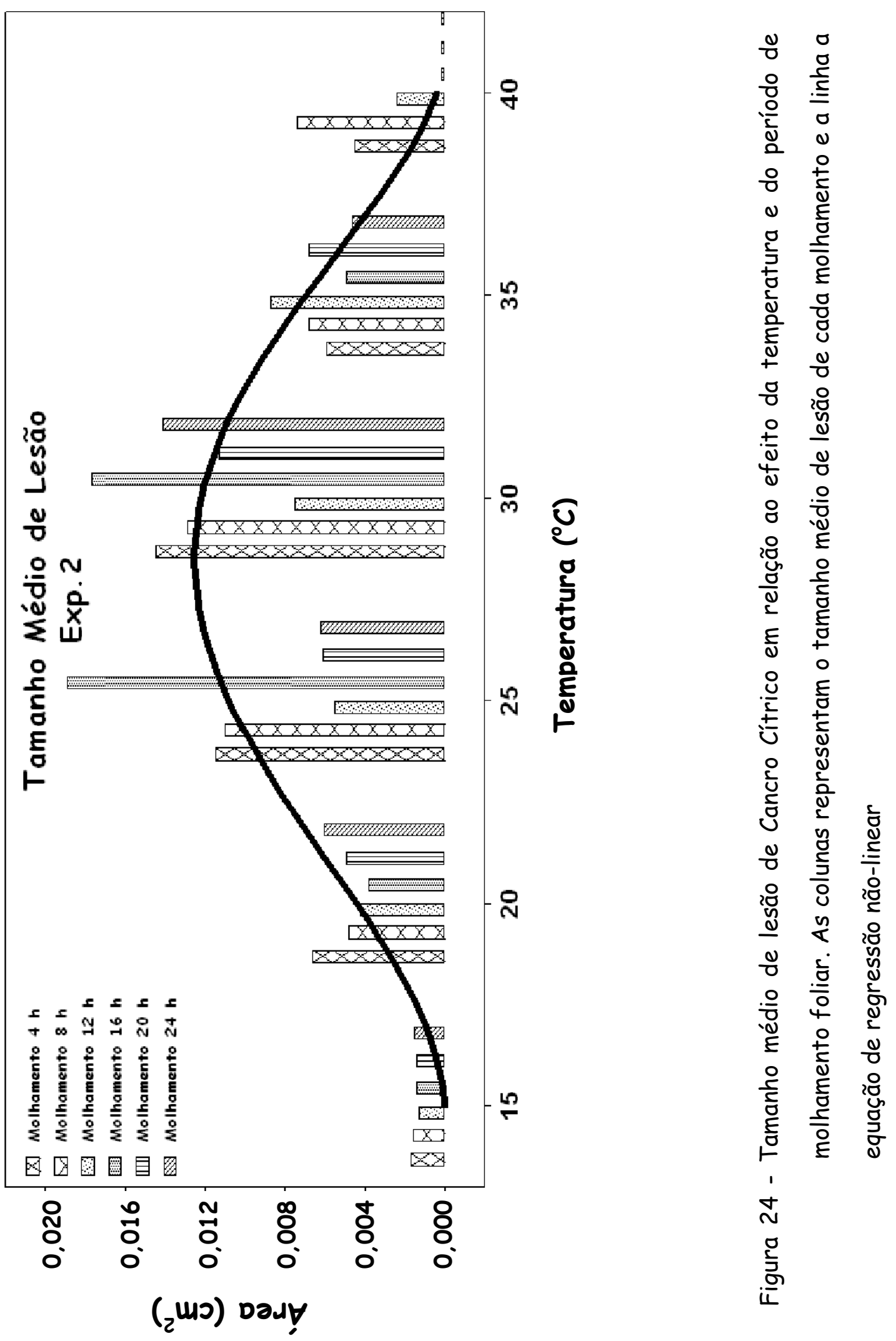
Tabela 14. Coeficiente de determinação $\left(R^{2}\right)$ e parâmetros estimados pela função Beta generalizada: $Y=b_{1}^{\star}\left(\left(T-b_{2}\right)^{b 4}\right)^{\star}\left(\left(b_{3}-T\right)^{b 5}\right)^{\star} b_{6}$ para ajuste da densidade e tamanho médio de lesão em relação à variação da temperatura e do período de molhamento. Sendo, y a severidade em porcentagem e T a temperatura $\left({ }^{\circ} \mathrm{C}\right)$

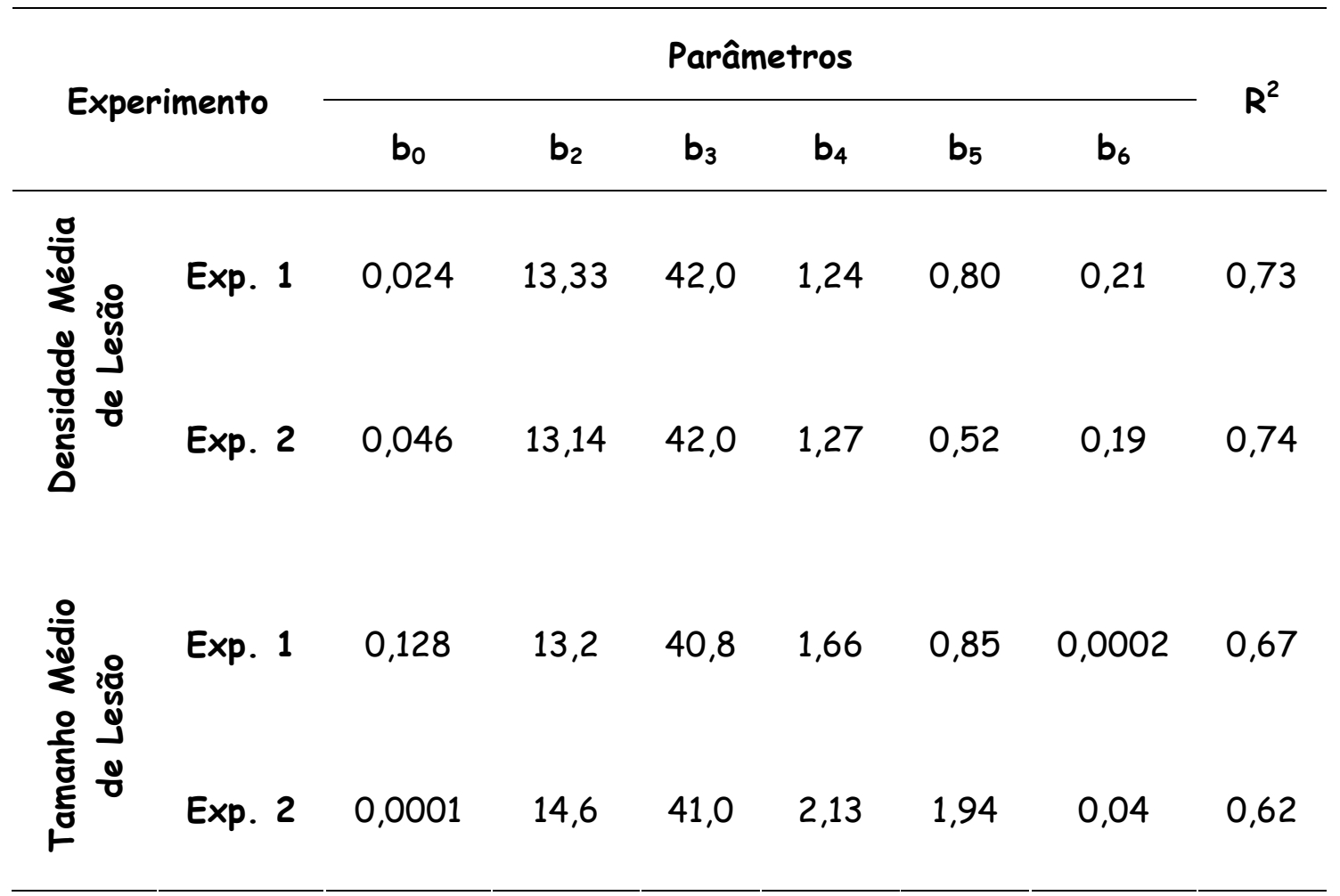



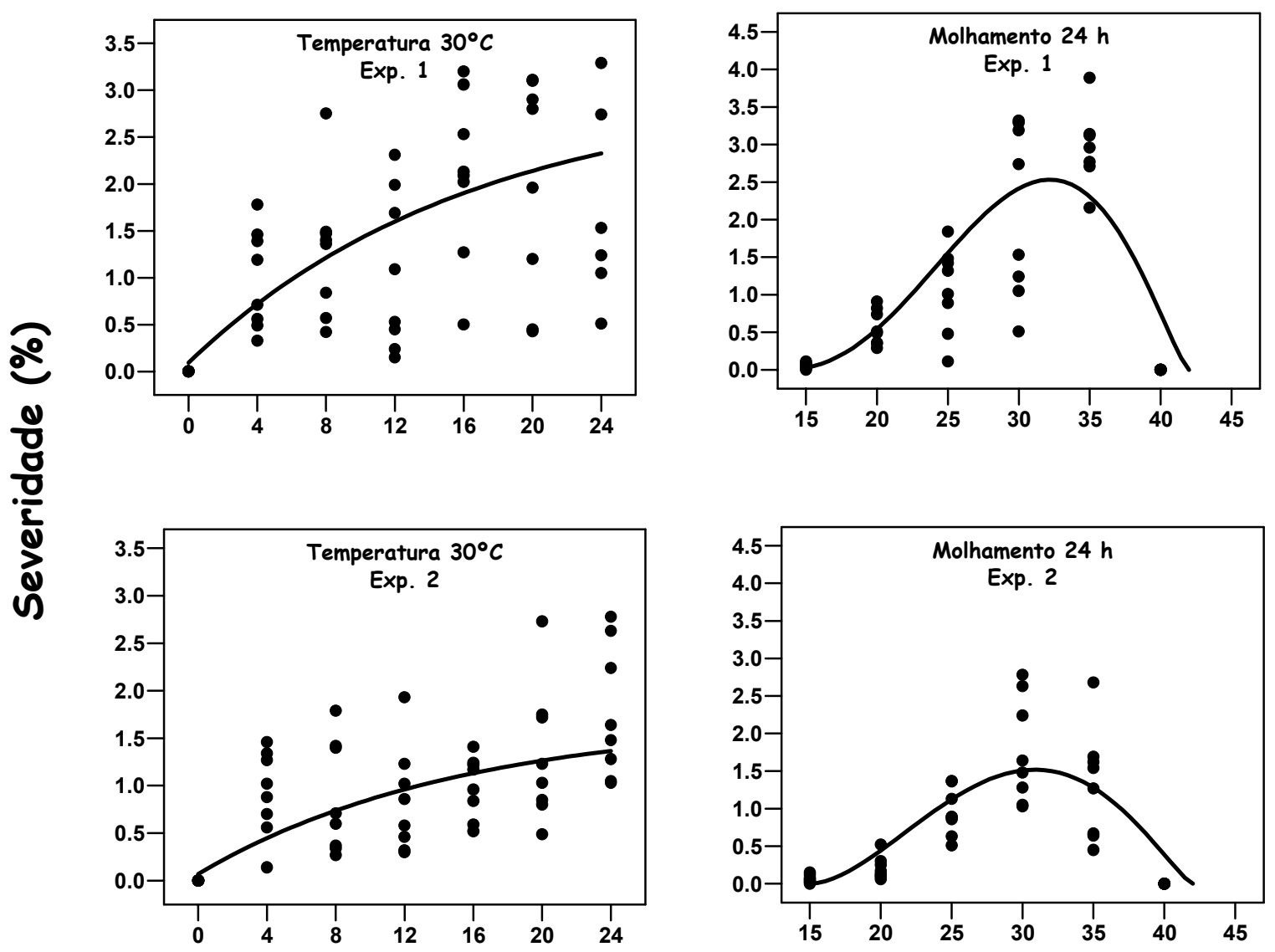

Molhamento Foliar (horas)

Temperatura $\left({ }^{\circ} \mathrm{C}\right)$

Figura 25 - Severidade de Cancro Cítrico em Limão Tahiti ajustada pelo modelo Monomolecular em diferentes períodos de molhamento foliar a $30^{\circ} \mathrm{C} \mathrm{e}$ pela função Beta generalizada em diferentes temperaturas com molhamento foliar de 24 horas 
Tabela 15. Equações e coeficientes de determinação $\left(R^{2}\right)$ obtidos nas regressões não-lineares, para ajuste dos dados de severidade de Cancro Cítrico, em função do período de molhamento foliar em cada uma das temperaturas dos experimentos 1 e 2

\begin{tabular}{|c|c|c|c|}
\hline & & Equação Monomolecular & $\mathbf{R}^{2}$ \\
\hline \multirow{6}{*}{ 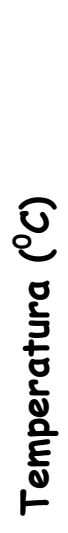 } & \multicolumn{3}{|c|}{ Experimento 1} \\
\hline & 15 & $y=(0,052)^{\star}\left(1-\left((1-(0,999))^{\star} \exp \left(-(0,062)^{\star} M\right)\right)\right)$ & 0,75 \\
\hline & 20 & $y=(0,55)^{\star}\left(1-\left((1-(0,994))^{\star} \exp \left(-(0,077)^{\star} M\right)\right)\right)$ & 0,91 \\
\hline & 25 & $y=(1,2)^{\star}\left(1-\left((1-(0,988))^{\star} \exp \left(-(0,078)^{\star} M\right)\right)\right)$ & 0,91 \\
\hline & 30 & $y=(2,9)^{\star}\left(1-\left((1-(0,971))^{\star} \exp \left(-(0,061)^{\star} M\right)\right)\right)$ & 0,88 \\
\hline & 35 & $y=(3,7)^{\star}\left(1-\left((1-(0,958))^{\star} \exp \left(-(0,051)^{\star} M\right)\right)\right)$ & 0,82 \\
\hline & 40 & Sem correlação & - \\
\hline \multicolumn{4}{|c|}{ Experimento 2} \\
\hline \multirow{6}{*}{ 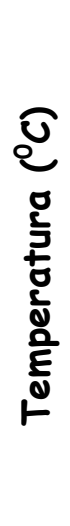 } & 15 & $\left.Y=\left(0,0007-((1-(0,999)))^{\star} \exp (-(0,053) \star M)\right)\right)$ & 0,73 \\
\hline & 20 & $y=(0,0022-((1-(0,997)) \star \exp (-(0,092) \star M)))$ & 0,77 \\
\hline & 25 & $y=\left(0,01-\left((1-(0,991))^{\star} \exp \left(-(0,097)^{\star} M\right)\right)\right)$ & 0,89 \\
\hline & 30 & $y=\left(0,018-\left((1-(0,983))^{\star} \exp (-(0,065) \star M)\right)\right)$ & 0,79 \\
\hline & 35 & $Y=\left(0,014-\left((1-(0,985))^{\star} \exp \left(-(0,114)^{\star} M\right)\right)\right)$ & 0,79 \\
\hline & 40 & $y=\left(0,004-\left((1-(0,996))^{\star} \exp \left(-(0,844)^{\star} M\right)\right)\right)$ & 0,98 \\
\hline
\end{tabular}

$Y=$ severidade em proporção

$M=$ molhamento (horas)

* = fator de multiplicação 
Tabela 16. Equações e coeficientes de determinação $\left(R^{2}\right)$ obtidos nas regressões não-lineares, para ajuste dos dados de severidade de Cancro Cítrico, em função da temperatura em cada um dos períodos de molhamento foliar dos experimentos 1 e 2

\begin{tabular}{|c|c|c|c|}
\hline & & Equação Beta generalizada & $\mathbf{R}^{2}$ \\
\hline \multirow{7}{*}{ 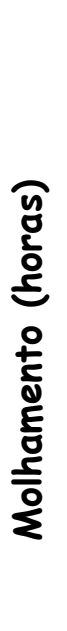 } & \multicolumn{3}{|c|}{ Experimento 1} \\
\hline & 4 & $y=(0,044)^{\star}\left((T-(15,0))^{(1,17)}\right)^{\star}\left(((42,0)-T)^{(0,81)}\right)^{\star}(0,07)$ & 0,42 \\
\hline & 8 & $Y=(0,047)^{\star}\left((T-(15,0))^{(1,51)}\right)^{\star}\left(((42,0)-T)^{(0,81)}\right)^{\star}(0,04)$ & 0,59 \\
\hline & 12 & $Y=(0,048)^{\star}\left((T-(15,0))^{(1,46)}\right)^{\star}\left(((42,0)-T)^{(0,73)}\right)^{\star}(, 061)$ & 0,49 \\
\hline & 16 & $Y=(0,01)^{\star}\left((T-(17,0))^{(1,45)}\right)^{\star}\left(((42,0)-T)^{(1,15)}\right)^{\star}(0,11)$ & 0,53 \\
\hline & 20 & $Y=(0,013)^{\star}\left((T-(14,9))^{(1,74)}\right)^{\star}\left(((42,5)-T)^{(1,23)}\right)^{\star}(0,039)$ & 0,48 \\
\hline & 24 & $y=(0.02)^{\star}\left((T-(13.0))^{(2.59)}\right)^{\star}\left(((42.0)-T)^{(1.32)}\right) \star(0.003)$ & 0.67 \\
\hline \multirow{7}{*}{ 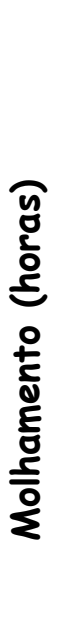 } & \multicolumn{3}{|c|}{ Experimento 2} \\
\hline & 4 & $Y=(, 023)^{\star}\left((T-(14,9))^{(1,73)}\right)^{\star}\left(((42,0)-T)^{(0,77)}\right)^{\star}(0,046)$ & 0,49 \\
\hline & 8 & $Y=(, 026)^{\star}\left((T-(15,0))^{(1,43)}\right)^{\star}\left(((42,0)-T)^{(1,10)}\right)^{\star}(0,054)$ & 0,56 \\
\hline & 12 & $Y=(0,02)^{\star}\left((T-(14,9))^{(1,45)}\right)^{\star}\left(((42,0)-T)^{(1,02)}\right)^{\star}(0,06)$ & 0,46 \\
\hline & 16 & $Y=(0,02)^{\star}\left((T-(15,0))^{(1,85)}\right) \star\left(((42,0)-T)^{(1,24)}\right)^{\star}(0,03)$ & 0,66 \\
\hline & 20 & $Y=(0,002)^{\star}\left((T-(10,7))^{(3,8)}\right)^{\star}\left(((42,3)-T)^{(1,68)}\right)^{\star}(0,0002)$ & 0,59 \\
\hline & 24 & $Y=(0,04)^{\star}\left((T-(14,9))^{(1,82)}\right)^{\star}\left(((42,0)-T)^{(1,28)}\right)^{\star}(0,01)$ & 0,69 \\
\hline
\end{tabular}

$Y=$ severidade em porcentagem

$\mathrm{T}=$ temperatura $\left({ }^{\circ} \mathrm{C}\right)$

* = fator de multiplicação 

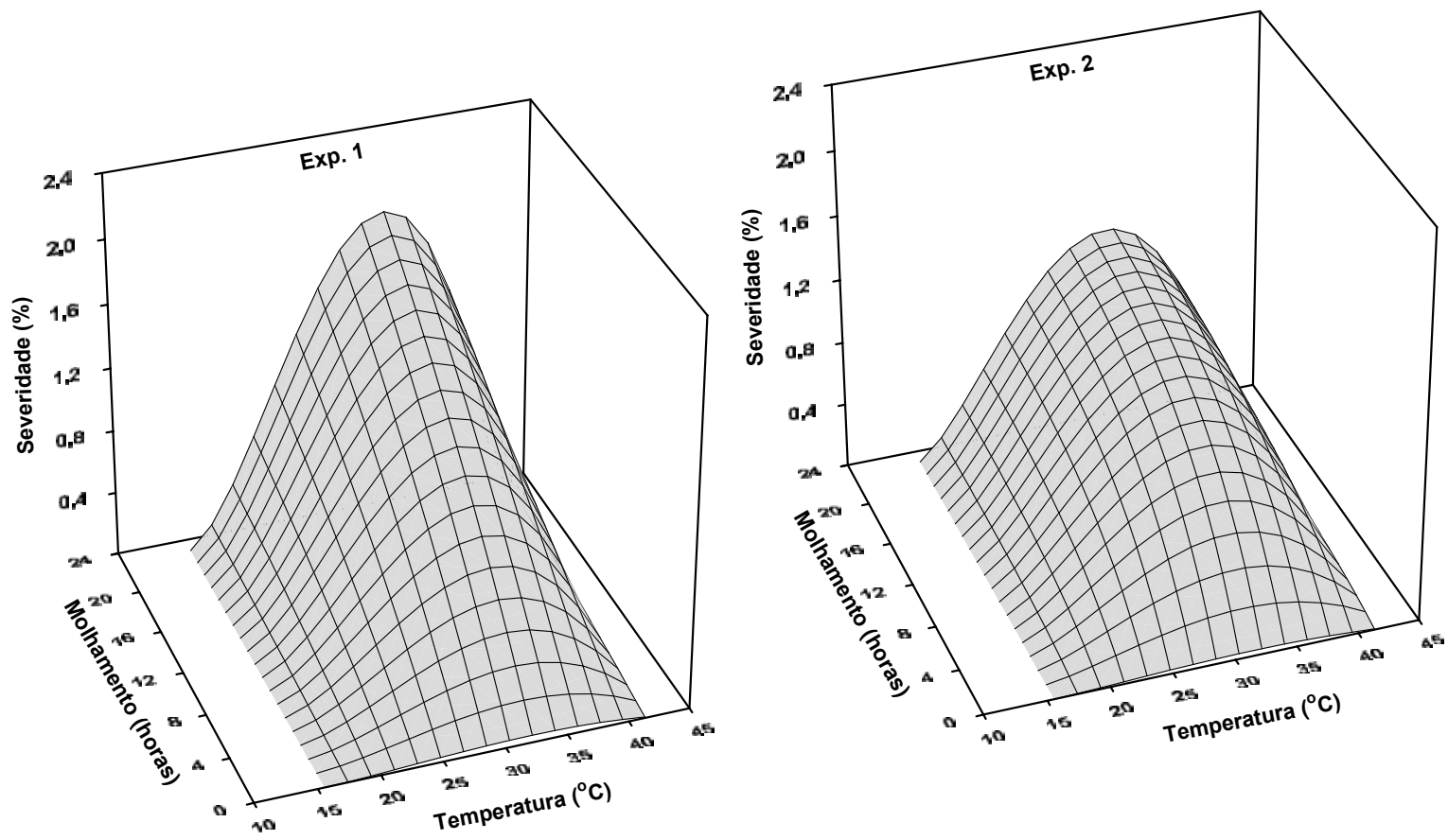

Figura 26 - Efeito da temperatura e do período de molhamento foliar na severidade de Cancro Cítrico em Limão Tahiti, dos experimentos 1 e 2, ajustado pela função Beta-Monomolecular

Tabela 17. Coeficiente de determinação $\left(R^{2}\right)$ e parâmetros estimados pela função Beta-Monomolecular: $\quad y=b 1^{\star}\left((T-b 2)^{b 4}\right)^{\star}\left((b 3-T)^{b 5}\right)^{\star} b 6^{\star}(1-((1-b 7) \star \exp (-$ $\left.\left.B 8^{\star} M\right)\right)$ ), sendo $Y$ a severidade $(\%)$, T a temperatura $\left({ }^{\circ} \mathrm{C}\right)$ e $M$ o período de molhamento foliar (horas)

\begin{tabular}{ccccccccccc}
\hline & \multicolumn{8}{c}{ Parâmetros } & \\
\cline { 2 - 9 } & $b_{0}$ & $b_{2}$ & $b_{3}$ & $b_{4}$ & $b_{5}$ & $b_{6}$ & $b_{7}$ & $b_{8}$ & \\
\hline Exp. 1 & 0,026 & 14,9 & 42,0 & 1,75 & 1,02 & 0,036 & 0,0108 & 0,026 & 0,80 \\
Exp. 2 & 0,019 & 14,9 & 42,0 & 1,56 & 1,01 & 0,048 & 0,0252 & 0,117 & 0,83 \\
\hline
\end{tabular}




\section{CONCLUSÕES}

Em relação à via de penetração de $X$. axonopodis pv. citri e a concentração de inóculo:

- a mínima concentração de inóculo para causar doença em mais de 50\% das mudas de Limão Tahiti em relação à via de penetração foi de $10^{4} \mathrm{UFC} / \mathrm{mL}$ via estômato; $10^{2}$ UFC/mL via ferimento mecânico e injúria de Lagarta Minadora dos Citros fase ovo e $1^{\circ}$ ínstar; e $10^{1} \mathrm{UFC} / \mathrm{mL}$ via injúria na fase $3^{\circ}$ ínstar e pupa.

- o período de incubação médio variou de 6 a 30 dias,respectivamente, em relação a maior e menor concentração testada.

- a injúria na fase $3^{\circ}$ ínstar e pupa proporcionaram maior severidade em relação às outras vias de penetração em todas as concentrações testadas.

- as severidades na fase $3^{\circ}$ ínstar e pupa foram, respectivamente, 5 e 6 vezes maiores que em folha intacta na concentração de $10^{6} \mathrm{UFC} / \mathrm{mL}$.

- as severidades em folha com ferimento mecânico e com injúria na fase ovo e $1^{\circ}$ instar não diferiram da severidade da folha intacta.

Em relação à idade da folha intacta, do ferimento mecânico e da injúria da Lagarta Minadora dos Citros: 
- o ferimento mecânico, a injúria e a folha intacta foram suscetíveis ao Cancro Cítrico, respectivamente, até aos 6,32 e 35 dias de idade.

- a severidade decresceu linearmente com o aumento da idade do ferimento e da folha intacta, enquanto que para a idade de injúria, a severidade variou em função do modelo Beta generalizado, com ponto de inflexão aos 18 dias. A máxima severidade estimada foi 10 vezes maior que em folha intacta.

- com relação à idade da injúria, o tamanho da lesão aumentou em razão da coalescência de inúmeras lesões até aos 16 dias, após o qual, diminuiu. Em folhas com injúria de LMC, o tamanho médio de lesão foi até 52 vezes maior que em folha intacta.

Em relação à temperatura e ao período de molhamento foliar:

- a temperatura influenciou a incidência da doença.

- o aparecimento das lesões ocorreu em maior tempo nas temperaturas mais baixas ( 24 dias a $15^{\circ} \mathrm{C}$ ) e em menor tempo nas temperaturas mais elevadas ( 8 dias a $30^{\circ} \mathrm{C}$ ).

- na temperatura de $40^{\circ} \mathrm{C}$, apenas nos períodos de molhamento de 4,8 e 12 horas foram observados sintomas e a incidencia desses períodos foi menor que $50 \%$.

- a condição ótima de temperatura e molhamento para o menor tempo de aparecimento das lesões e $100 \%$ de incidência foi de 25 a $35^{\circ} \mathrm{C}$ e duração mínima de molhamento de 4 horas.

- a variação do período de molhamento pouco influenciou a incidência. 
- a densidade e o tamanho de lesão foram influenciados somente pela temperatura. Ambos foram explicados pela função Beta generalizada, com ponto de inflexão de $32,5^{\circ} \mathrm{C}$ e $29,5^{\circ} \mathrm{C}$, respectivamente.

- o modelo monomolecular e a função Beta generalizada apresentaram bom ajuste para os dados de períodos de molhamentos e temperatura, respectivamente.

- a função Beta-monomolecular ajustou-se a variação da severidade em relação à temperatura e à duração do molhamento foliar.

-as temperaturas mínimas e máximas estimadas pelo modelo acima foram de 14,9 e $42^{\circ} \mathrm{C}$

- a máxima severidade foi determinada no molhamento de 24 horas a $31,7^{\circ} \mathrm{C}$.

Por esses resultados, conclui-se que a Lagarta Minadora dos Citros tem papel relevante na epidemiologia do Cancro Cítrico. 
ANEXO 

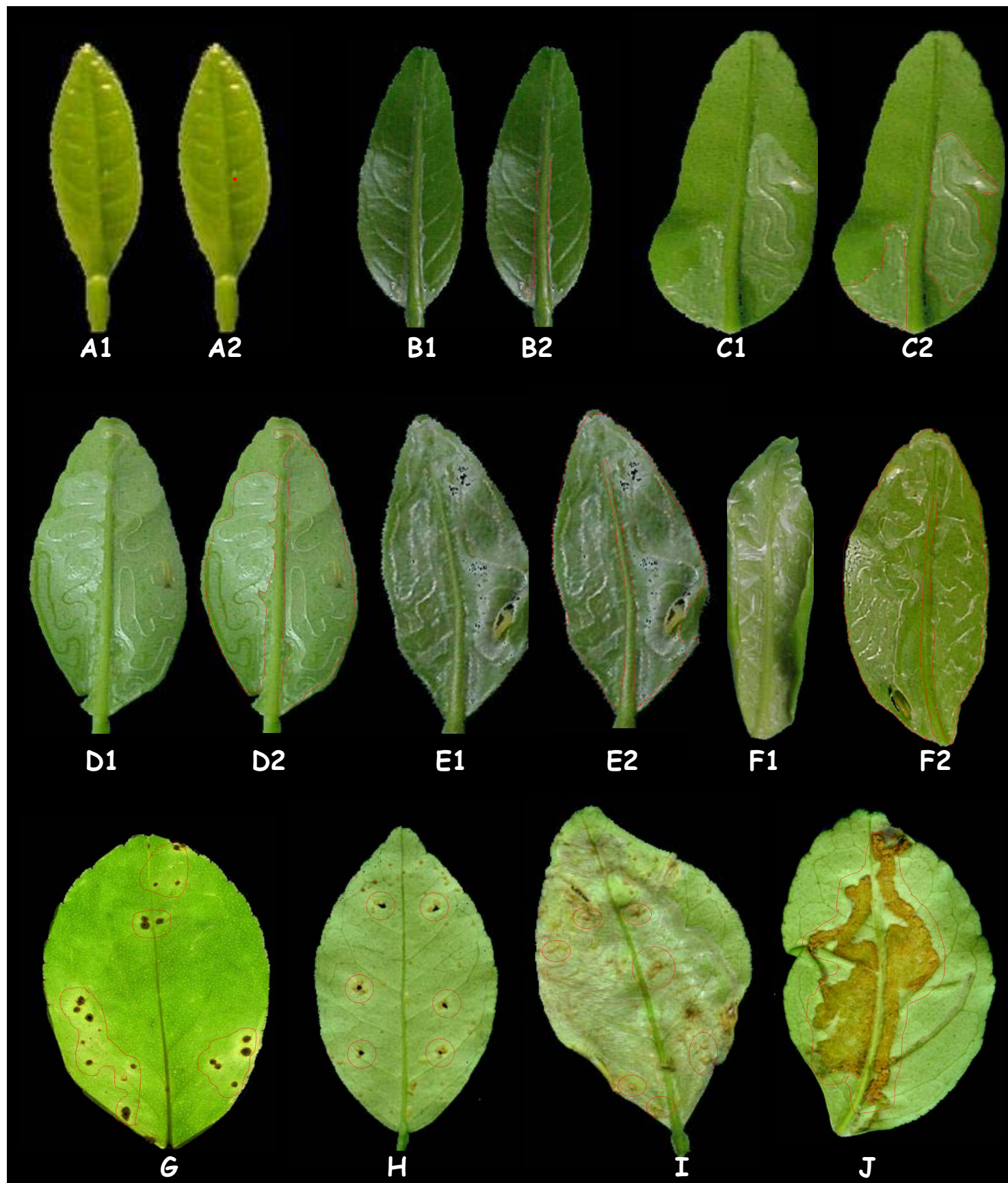

Figura 27- Folhas de Limão Tahiti. De $\mathbf{A}$ a F, injúrias de LMC das fases: A1- ovo; B1- $1^{\circ}$ ínstar; C1- $2^{\circ}$ instar; D1 - $3^{\circ}$ ínstar; E1- $4^{\circ}$ ínstar; F1- pupa. De $A 2$ a F2, área da injúria de LMC circundada por pontilhado vermelho. De $G$ a $I$, lesões de Cancro Cítrico, circundados por pontilhados vermelhos, obtidos por aspersão de inóculo: G- folha intacta; $\mathrm{H}$ - folha com ferimento mecânico; I- folha com injúria de LMC fase ovo; J- folha com injúria de LMC fase pupa. Figuras sem escala 


\section{REFERÊNCIAS BIBLIOGRÁFICAS}

AGOSTINI, J.P.; GRAHAM, J.H.; TIMMER, L.W. Relationship between development of citrus canker and rootstock cultivar for young 'Valencia' orange trees in Misiones, Argentina. Proceedings of the Florida State Horticultural Society, v.98, p.19-22, 1985.

ALBA, C.G. El minador de los citricos, Phyllocnistis citrella, Stainton. Introduccion y comportamento em España. Descripcion, daños y caracterizacón ecológica: estratégia de lucha. Malaga: Consejeria de Agricultura y Pesca, 1996. $18 p$.

AMORIM, L.; BERGAMIN FILHO, A. A epidemiologia do Cancro Cítrico. Summa Phytopathologica, v.27, n.1, p.151-156, 2001.

ARGOV, Y.; ROSSLER, Y. Introduction, release and recovery of several exotic natural enemies for biological control of the citrus leafminer, Phyllocnistis citrella, in Israel. Phytoparasitica, v.24, p.33-38, 1996.

BADAWY, A. The morphology and biology of Phyllocnistis citrella Stainton, a citrus leafminer in the Sudan. Bulletin de la Societe Entomologique du Egypte, v. 51, p.95-103, 1967.

BANZATTO, D.A; KRONKA, S.N. Experimentação agrícola. 3. Ed. Jaboticabal: FUNEP, 1995. 245p. 
BARBOSA, J.C.; FERNANDES, N.G. Incidência e distribuição de cancro cítrico no Estado de São Paulo. Jaboticabal: FUNEP, 1999. 11 p.

BATRA, R.C.; SANDHU, S.C.; SHARMA, S.C.; SINGH, R. Biology of the citrus leafminer on some rootstocks and its relationships with abiotic factors. The Punjab Horticultural Journal, v.28, n.2, p.30-35, 1988.

BERGAMIN FILHO, A.; AMORIM, L. Doenças de plantas tropicais: epidemiologia e controle econômico. São Paulo, Ceres, 1996. 299 p.

BERGAMIN FILHO, A.; AMORIM, L.; GOTTWALD, T.R.; LARANJEIRA, F.F. Spatial distribution of citrus canker in São Paulo - Brazil. In: INTERNACIONAL WORKSHOP ON PLANT DISEASE EPIDEMIOLOGY, 8; Ouro Preto, 2001. Proceeding: Ouro Preto: International Society of Plant Phatology, 2001. p.28-29.

BRUNINGS, A.M.; GABRIEL, D.W. Xanthomonas citri: breaking the surface. Molecular Plant Pathology, v.4, n.3, p.141-157, 2003.

CASTELLANI, A. Viability of some pathogenic fungi in distilled water. Journal of Tropical Medicine and Hygiene, v.42, p.225, 1939.

CHAGAS, M.C.M.; PARRA, J.R.P. Phyllocnistis citrella Stainton (Lepidoptera: Gracillariidae): técnica de criação e biologia em diferentes temperaturas. Anais da Sociedade Entomológica do Brasil, v.29, p.227-235, 2000.

CHAGAS, M.C.M.; PARRA, J.R.P.; NAMEKATA, T.; HARTUNG, J.S.; YAMAMOTO, P.T. Phyllocnistis citrella Stainton (Lepidoptera: gracillariidae) and its reatioships with the citrus canker bacterium Xanthomonas axonopodis pv citri in Brazil. Neotropical Entomology, v.30, p.55-59, 2001. 
CHEN, M.S.; LE, X.N. A preliminary study on Elachertus sp. - an ectoparasite of Phyllocnistis citrella. Journal of Fujian Agricultural College, v.15, p.123-131, 1986.

CHIARADIA, L.A.; MILANEZ, J.M. "Lagarta minadora-dos-citros", uma nova praga na citricultura catarinense. Agropecuária Catarinense, v.10, n.3, p.20-21, 1997.

CLAUSEN, C.P. two citrus leaf miners of the far east. Technical Bulletin of the U.S Department of Agriculture, v.252, 1931.13p.

COOK, A.A. Association of citrus canker pustules with leafminer tunnels in North Yemen. Plant Disease, v.72, n.6, p.544-546, 1988.

DOPSON, R. N. The eradication of citrus canker. Plant Disease Reporter, v.48, p.30-31, 1964.

FAWCETT, H.S.; JENKINS, A.E. Records of citruscanker from herbarium specimens of the genus Citrus in England and the United States. Phytopathology v.23, p. 820-824, 1933.

FEICHTENBERGER, E.; RAGA, A. First Record of citrus leafminer Phyllocnistis citrella (Lep.: Gracillariidae) in Brazil. In: CONGRESSO BRASILEIRO DE FRUTICULTURA, 14; Curitiba, 1996. Anais. Curitiba: SBF, 1996. p.445.

FEICHTENBERGER, E.; MÜLLER, G.W.; GUIRADO, N. Doenças dos citros (Citrus spp.). In KIMATI, H.; AMORIM, L.; BERGAMIN FILHO, A.; CAMARGO, L.E.A.; REZENDE, J.A.M. (Ed.). Manual de Fitopatologia. Doenças das plantas cultivadas. São Paulo: Ceres, 1997. p. 261-296.

FNP CONSULTORIA \& COMERCIO. AGRIANUAL, 2003. Anuário da agricultura brasileira. São Paulo, 2003, 544p. 
FUNDECITRUS. Cancro cítrico. http://www.fundecitrus.com.br/cancro.html (10 nov. 2003)

GABRIEL, D.W., KINGSLEY, M.T., HUNTER, J.E.; GOTTWALD, T.R. Reinstatement of Xanthomonas citri (ex Hasse) and X. phaseoli (ex Smith) to species and reclassification of all $X$. campestris pv. citri strains. International Journal System Bacteriology, v.39, p.14-22, 1989.

GARIJO, C.: GARCIA, E.J. Phyllocnistis citrella (Stainton, 1856) (Insecta:Lepidoptera: Gracillariidae: Phyllocnistinae) em los cultivos de citricos de andalucia (Sur España): biologia, ecologia y control de la plaga. Boletin de Sanidad Vegetal: Plagas, v.20, n.4, p.815-816, 1994.

GODOY, C.V.; AMORIM, L.; BERGAMIN FILHO, A. Influência da duração do molhamento foliar e da temperatura no desenvolvimento da ferrugem do milho causada por Puccinia polysora. Fitopatologia Brasileira, v.24, p.160-165, 1999.

GOODMAN, R. N. The infection process. In: M. S. MOUNT AND G. H. LACY Phytopathogenic Prokariotes. London: Academic Press, 1982, v.1, p.31-62.

GOTO, M. Studies on citrus canker. In: INTERNATIONAL CITRUS SYMPOSIUM, 12; Riverside, 1962. Proceeding. Riverside:University of California, Riverside, 1962. p.3-72.

GOTO, M. Fundamentals of bacterial plant pathology. San Diego: Academic Press. 1990. 342 p.

GOTO, M. Citrus canker. In: KUMAR, J., CHAUBE, H.S., SINGH, U.S., MUKHOPADHYAY, A.N. Plant Diseases of International Importance. Englewood Cliffs: Prentice Hall, 1992, p.250-269. 
GOTO, M.; HYODO, H. Role of extracellular polysaccharides of Xanthomonas campestris pv. citri in the early stage of infection. Annual Phytopathology Society Japan, v.51, p.22-31, 1985.

GOTO, M., OHTA, K; OKABE, N. Studies on saprophytic survival of Xanthomonas citri (Hasse) Dowson. 2. Longevity and survival density of the bacterium on artificially infested weeds, plant residues and soils. Annual Phytopathology Society Japan, v.41, p.141-147, 1975.

GOTTWALD, T.R.; GARNEY, S.M. Major citrus diseases in southeast Asia. Citrus Industry, v 71, p.58-63, 1991.

GOTTWALD, T.R.; GRAHAM, J.H. A device for precise and nondisruptive stomatal inoculation of leaf tissue with bacterial pathogens. Phytopathology, v.82, n.9, p.930-935, 1992.

GOTTWALD, T.R.; TIMMER, L.W. The efficacy of windbreaks in reducing the spread of citrus canker caused by Xanthomonas campestris pv. citri. Tropical Agriculture, v.72, n.3, p.194-201, 1995.

GOTTWALD, T. R.; GRAHAM, J.H.; EGEL, D.S. Analysis of foci of Asiatic citrus canker in a Florida citrus orchard. Plant Disease, v.76, n.4, p.389-396, 1992.

GOTTWALD, T. R.; GRAHAM, J.H.; SCHUBERT, T.S. Citrus canker in urban Miami: An analysis of spread and prognosis for the future. Citrus Industry, v.78, n.8, p.72-78, 1997.

GOTTWALD, T.R., GRAHAM, J.H., CIVEROLO, E.L., BARRETT, H.C.; HEARN, C.J. Differential host range reaction of citrus and citrus relatives to citrus canker and citrus bacterial spot determined by leaf mesophyll susceptibility. Plant Disease, v.77, p.1004-1009, 1993. 
GOTTWALD, T.R., MCGUIRE, R.C.; GARRAN, S. Asiatic citrus canker: spatial and temporal spread in simulated new planting situations in Argentina. Phytopathology, v.78, p.739-745, 1988.

GRAHAM, J.H. Varietal susceptibility to citrus canker: Observations from southern Brazil. Citrus Industry, v.82, n.6, p.15-17, 2001.

GRAHAM， J.H., GOTTWALD， T.R.; FARDELMANN, D. Cultivar-specific interactions for strains of Xanthomonas campestris from Florida that cause citrus canker and citrus bacterial spot. Plant Disease, v.74, n.10, 753-756, 1990.

GRAHAM, J.H., GOTTWALD, T.R., CIVEROLO, E.L.; MCGUIRE, R.G. Population dynamics and survival of Xanthomonas campestris pv. citri in soil in citrus nurseries in Maryland and Argentina. Plant Disease, v.73, n.5, p.423-427, 1989.

GRAHAM, J.H., GOTTWALD, T.R., RILEY, T.D.; ACHOR, D. Penetration through leaf stomata and strains of Xanthomonas campestris in citrus cultivars varying in susceptibility to bacterial diseases. Phytopathology, v.82, n.11, p.1319-1325, $1992 a$.

GRAHAM, J.H., GOTTWALD, T.R., RILEY, T.D.; BRUCE, M.A. Susceptibility of citrus fruit to bacterial spot and citrus canker. Phytopathology, v.82, n.4, p.452-457, $1992 b$.

GRAHAM, J.H., GOTTWALD, T.R., RILEY, T.D., CUBERO, J.; DROUILLARD, D.L. Survival of Xanthomonas campestri pv. citri on various surfaces and chemical control of Asiatic citrus canker. In: INTERNATIONAL CITRUS CANKER RESEARCH WORKSHOP, Fort Pierce, 2000. Proceeding. http://doacs.state.fl.us/canker (9 Nov. 2003) 
HAU, B.; KRANZ, J. Mathematics and statistics for analysis in epidemiology. In Kranz, J. (Ed.). Epidemics of plant diseases. Mathematical analysis and modeling. Berlin: Springer, 1990. p.12-52.

HEPPNER, J.B. Citrus leafminer (Lepidoptera: Gracillariidae) on fruit in Florida. Florida Entomologist, v.78, n.1, p.182-186, 1995.

HEPPNER, J.B. Citrus leafminer, Phyllocnistis citrella, in Florida (Lepidoptera: Gracillariidae: Phyllocistinae). Tropical Lepidoptera, v.4, p.49-64, 1993.

HOY, M.; NGUYEN, R.; POMERINK, M.; BULLOCK, R.; HALL, D.; KNAPP, J.; PENA, J.; BROWNING, H.; STANSLY, P. Distribution of A. citricola- a parasite of the citrus leafminer. Citrus Industry, v.75, n.5, p.51-52, 1997.

HUANG, M.D.; LI, S.X. The damage and economic threshold of citrus leaf miner, Phyllocnistis citrella Stainton to citrus. In: CHANG, C.X.; HUANG, M.D.; LI, S.X.; MAI, X.H.; TAN, W.C.; SZETU, J. Studies on the integrated management of Citrus insect pests. Guangzhou: Academic Book \& Periodical Press, 1989, p.84-89.

HUANG, M.D.; CHANG, C.X.; LI, S.X.; MAI, X.H.; TAN, W.C.; SZETU, J. Studies on annual population dynamics and control strategy of the citrus leaf miner. In: CHANG, C.X.; HUANG, M.D.; LI, S.X.; MAI, X.H.; TAN, W.C.; SZETU, J. Studies on the integrated managment of Citrus insect pest. Guangdong: Academic Book \& Periodical Press, 1989, p.63-75.

HUTSON, J.C.; PINTO, M.P.D. Two caterpillar pests of citrus. Tropical Agriculturist, v.83, p.188-193, 1934.

KNAPP, J.; PEÑA, J.; STANSLY, P.; HEPPNER, J.; YANG, Y. Citrus Leafminer, a new pest of citrus in Florida. Citrus Industry, v.74, n.10, p.42-43, 1993. 
KOIZUMI, M. Resistance of citrus plants to bacterial canker disease. In: INTERNATIONAL SOCIETY OF CITRICULTURE, 1; Tokyo, 1981. Proceeding. Tokyo: ISC, 1981. p.402-405.

KOIZUMI, M.; KIMIJIMA, E.; TSUKAMOTO, T.; TOGAWA, M; MASUI, S. Dispersion of citrus canker bacteria in droplets and prevention with windbreaks. In: INTERNATIONAL SOCIETY OF CITRICULTURE; Tokyo, 1996. Proceeding. Tokyo: ISC, 1996. p.340-344.

KOIZUMI, M.; KUHARA, S. Evaluation of citrus plants for resistance to bacterial canker disease in relation to lesion extension. Bulletin Tree Fruit Research, v.4, p.73-92, 1982.

KRANZ, J.; HAU, B. Systems analysis in epidemiology. Annual Review of Phytopathology, v.18, p.67-83, 1980.

LEE, H. A. Relation of the age of citrus tissues to the susceptibility to citrus canker. Journal of the Science, v.20, n.3, p.331-341, 1922.

LEITE JUNIOR., R.P. Integrated management of the citrus bacterial canker disease caused by Xanthomonas campestris pv. citri in the State of Paraná, Brazil. Crop Protection, v.9, p.3-7, 1990.

LEITE, R.P. JUNIOR; MOHAN, S.K. Evaluation of citrus cultivars for resistance to canker caused by Xanthomonas campestris pv. citri (Hasse) Dye in the State of Paraná, Brazil. Proceedings of the International Society of Citriculture, v.1, p.385-389, 1984.

LIMA, A.F.; AGUIAR, L.A. Ocorrência e infestação de larva minadora dos citros Phyllocnistis citrella (Lepidoptera: Gracillariidae) no Estado do Rio de Janeiro. 
In: CONGRESSO BRASILEIRO DE ENTOMOLOGIA, 16; Salvador, 1997. Anais. Salvador: SEB, 1997, p.229.

LOLATO, A.; MORAES, J.C. Ocorrência da "Lagarta Minadora das Folhas de Citros" Phyllocnistis citrella Stainton, 1856 (Lepidoptera: Gracilariidae) em Lavras, sul de Minas Gerais. Ciência e Agrotecnologia, v.21, n.4, p.521-522, 1997.

LOPES, C.M.D'A.; PAMPLONA, A.M.S.R.; TELES, B.R. Ocorrência e levantamento do minador das folhas de citros Phyllocnistis citrella (Lepidoptera: gracillariidae) no Estado do Amazonas. In: CONGRESSO BRASILEIRO DE ENTOMOLOGIA, 16., Salvador, 1997. Anais. Salvador: SEB, 1997. p.285.

MATSUMOTO, R.; OKUDAI, N. An early evaluation of citrus seedlings for the resistance to bacterial canker disease Xanthomonas campestris pathovar citri by a needle prick inoculation. Bulletin Fruit Tree Research, v.9, p.11-24, 1988.

MAY-DE MIO, L.L.; AMORIM, L. Influência da temperatura e da duração do molhamento foliar nos componentes monocíclicos da ferrugem do álamo. Summa Phytopathologica, v.28, p.33-40, 2002.

MCLEAN, F.T. A study of the structure of stomata of two species of citrus in relation to citrus canker. Bulletin of Torrey Botanic Club, v.48, p.101-106, 1921

MCLEAN, F.T.; LEE, A.H. The resistance to citrus canker of Citrus nobilis and a suggestion as to the production of resitant varieties in other Citrus species. Phytopathology, v.11, p.109-114, 1921.

MORAES, L.A.H.; SOUZA, E.L.S.; BECKER, R.F.P.; BRAUN, J. Controle químico do minador-das-folhas dos citros Phyllocnistis citrella Stainton,m 1856. Pesquisa Agropecuária Gaúcha, v.5, n.1, p.19-22, 1999. 
MOREIRA, M.A.B.; MEDEIROS, R.D.; DUARTE, O.R. Ocorrência e avaliação do dano da lagarta minadora dos citros Phyllocnistis citrella (Lepidoptera: Gracillariidae) em Roraima. In: CONGRESSO BRASILEIRO DE ENTOMOLOGIA, 16., Salvador, 1997. Anais. Salvador:SEB, 1997. p.88.

NASCIMENTO, F.N.; SANTOS, W.S.; CASSINO, P.C.R. Parasitismo em larvas de Phyllocnistis citrella, Stainton (Lepidóptera: Gracillariidae) no Estado do Rio de Janeiro. Anais da Sociedade Entomológico Brasileira, v.29, n.2, p.377-379, 2000.

NASCIMENTO, J.F.; RODRIGUES NETO, J.; ALVES, J.M.A.; RÊGO, M.M.; ARAÚJO, A.E.S. Ocorrência De Cancro Cítrico No Estado De Roraima. In: CONGRESSO PAULISTA DE FITOPATOLOGIA, 26., Araras, 2003. Anais. Araras: CPF, 2003. CD-Rom.

NEAKE, C.; SMITH, D.; BEATTIE, G.A.C.; MILES, M. Importation host specifity testing rearing and release of three parasitoid of Phyllocnistis citrella Stainton (Lepidoptera: Gracillariidae) in Eastern austrália. Journal of the Australian Entomological Society, v.34, p.343-348, 1995.

PAIVA, P.E.B.; BENVENGA, S.R.; GRAVENA, S. Observações sobre a lagarta minadora dos citros e seus parasitóides no Estado de São Paulo. Laranja, v.19, n.2, p.285-292, 1998.

PALAZZO, D.A.; MALAVOLTA JUNIOR., V.A.; NOGUEIRA, E.M.C. Influência de alguns fatores climáticos sobre o índice de infecção de cancro cítrico, causada por Xanthomonas campestris pv. citri, em laranjeira valência (Citrus sinensis), em Bataguassu, M.S. Fitopatologia Brasileira v.9, n.2, p.283-290, 1984. 
PELTIER, G.L. Further studies on the relative susceptibility to citrus canker on different species and hybrids of the genus Citrus, including the wild relatives. Journal Agriculture Research, v.28, p.227-239, 1924

PEÑA, J.E.; DUNCAN, R.; BROWNING, H. Seasonal abundance of Phyllocnistis citrella (Lepidoptera: Gracillariidae) and its parasitoids in south Florida citrus. Environmental Entomology, v.25, n.3, p.698-702, 1996.

PEREIRA, A.L., WATANABE, K., ZAGATTO, A.G.; CIANCIULLI, P.L. Survival of Xanthomonas citri (Hasse) Dowson, the causal agent of 'citrus canker' in the rhizosphere of guineagrass (Panicum maximum Jacq.). Biologico, v.44, p.135-138, 1978.

PEREIRA, A.L., WATANABE, K., ZAGATTO, A.G.; CIANCIULLI, P.L. Survival of Xanthomonas citri (Hasse) Dowson [ the causal agent of 'citrus canker] on sourgrass (Trichachne insularis (L.) Ness) from eradicated orchads in the State of São Paulo, Brazil. Biologico, v.42, p.217-221, 1976.

PERIOTO, N.W. Primeira ocorrência do Gênero Galeopsomyia Girault (Hymenoptera: Chalcidoidea: Eulophidae) para o Brasil. O Biológico, v.59, n.l, p.97-98, 1997.

PRATES, H.S.; NAKANO, O.; GRAVENA, S.A. "Minadora das folhas de citros" Phyllocnistis citrella, Stainton, 1856. Campinas: CATI, 1996. 3p.

PRUVOST, O.; GOTTWALD, T.R.; BROCHERIEUX, $C$. The effect of irrigation practices on the spatio-temporal increase of Asiatic citrus canker in simulated nursery plots in Reunion Island. European Journal of Plant Pathology, v.105, p.23-27, 1999. 
QUADLING, C. Preservation of Xanthomonas by freezing in glycerol broth.

Canadian Journal of Microbiology, v.6, p.475, 1960.

RADKE, S.G.; KANDLKAR, H.G. Bionomics of citrus leafminer. PKV Research Journal, v.11, p.9102, 1987.

RODRIGUES, J.C.V.; ROSSETTI, V.; MACHADO, M.A.; TEÓFILO SOBRINHO, J.; NOGUEIRA, N.L. Lagarta minadora dos citros: um fator do aumento de pragas $e$ cancro cítrico. Laranja, v.19, n.1, p.49-60, 1998.

ROSSETTI, V. Citrus canker in Latin America: a review. Proceedings of the International Society of Citriculture v.3, p.918-924, 1977.

ROSSETTI, V.; FEICHTENBERGER, E.; SILVEIRA, M.L. Cancro cítrico (Xanthomonas campestris pv. citri): bibliografia analítica. São Paulo, Instituto Biológico, 1981. 203 p.

ROTEM, J. Techniques of controlled-condition experiments. In Kranz, J. ROTEM, J. (Ed.). Experimental techniques in plant disease epidemiology. Berlin: Springer, 1988. p. 19-31.

SACARIAS, E.N.; CANALES, A.C. Ageniaspis citricola Logvinovskaya, 1983 (Hymenoptera: encyrtidae) controlador de Phyllocnistis citrella "minador de la hoja de los citros": experiência peruana. Lima: SENASA, 1999. 88p.

SCHAAD, N.W.; VIDAVER, A.K.; LACY, G.H.,; RUDOLPH, K.; JONES, J.B. Evaluation of proposed amended names of several Pseudomonads and Xanthomonads and recommendations. Phytopathology, v.90, n.3, p.208-213, 2000. 
SCHUBERT, T.S.; RIZVI, S.A.; SUN, X.; GOTTWALD, T.R.; GRAHAM, J.H.; DIXON, W.N. Meeting the challenge of eradicating citrus canker in FloridaAgain. Plant Disease, v.85, n.4, p.340-356, 2001.

SILVA, P.H.S.; SILVA, R.B.Q.; MENESES, R.V.S.; COSTA, R.L. Ocorrência do minador dos citros Phyllocnistis citrella Stainton, 1856 (Lepidoptera: Gracillariidae) em Teresina-PI. Ciência e Agrotecnologia, v.21, n.3, p.393-394, 1997.

SOHI, G.S.; SANDHU, M.S. Relationship between Citrus leafminer (Phyllocnistis citrella Stainton) injury and Citrus canker (Xanthomonas citri (Hasse) Dowson) incidence on citrus leaves. Journal of Research of the Punjab Agricultural University, v.5, p.66-69, 1968.

SOUZA, A.C., BEZERRA, E.S. Agronegócio nacional: uma análise das principais cadeias e sugestões para o ganho competitivo. Rio de Janeiro: UFRRJ, 2000. http://pa.esalq.usp.br/andr0501.pdf (29 Nov. 2003)

SPONAGEL, KW.; DIAZ, F.J.EI minador de lãs hojas de los citricos Phyllocnistis citrella, um insecto plaga de importancia economica em ia citricultura de Honduras. Lima: FHA, 1994, 32p.

STALL, R.E., MARCO, G.M., CANTEROS DE ECHENIQUE, B.I. Importance of mesophyll in mature-leaf resistance to cancrosis of citrus. Phytopathology, v.72, n. 8, p.1097-1100, 1982.

STALL, R.E.; MILLER, J.W.; MARCO, G.M.; CANTEROS DE ECHENIQUE, B.I. Population dynamics of Xanthomonas citri causing cancrosis in Argentina. Proceedings of the Florida State Horticultural Society, v.93, p.10-14, 1980. 
TIMMER, L.W., GOTTWALD, T.R.; ZITKO, S.E. Bacterial exudation from lesions of Asiatic citrus canker and citrus bacterial spot. Plant Disease, v.75, n.2, p.192$195,1991$.

VALE, F.X.R.; FERNANDES FILHO, E.I.; LIBERATO, J.R.; ZAMBOLIM, L. QuantA software to quantify plant disease severity. In: INTERNACIONAL WORKSHOP ON PLANT DISEASE EPIDEMIOLOGY, 8; Ouro Preto, 2001. Proceedings. Ouro Preto, International Society of Plant Phatology, 2001. p.160.

VANDERPLANK, J.E. Plant diseases: epidemics and control. New York. Academic. 1963. 349 p.

WILSON, C.G. Notes on Phyllocnistis citrella, Staiton (Lepidóptera:Phyllocnistidae) attacking four citrus varieties in Darwin. Journal of the Australian Entomological Society, v.30, p.77-78, 1991.

ZUBRZYCKI, H. M.; ZUBRZYCKI A.D. Resistance to Xanthomonas campestris pv. citri (Hasse) Dowson in oranges (Citrus sinensis (L.) Osbeck). In: INTERNATIONAL SOCIETY OF CITRICULTURE, 1; Tokyo, 1981. Proceeding. Tokyo: ISC, p.405-409.

ZUBRZYCKI, H. M.; ZUBRZYCKI, A.D. Relationship between the amount of inoculum and the infection caused by Xanthomonas campestris pv. citrion citrus seedlings through natural infections in the field. In: INTERNATIONAL SOCIETY OF CITRICULTURE; Tokyo, 1987. Proceeding. Tokyo: ISC, p.379382. 